Florida International University FIU Digital Commons

$6-27-2018$

\title{
Occurrence and Consequences of Surprise Internal Control Disclosures
}

Hambisa Belina

hbeli007@fiu.edu

DOI: $10.25148 /$ etd.FIDC006872

Follow this and additional works at: https://digitalcommons.fiu.edu/etd

Part of the Accounting Commons

\section{Recommended Citation}

Belina, Hambisa, "Occurrence and Consequences of Surprise Internal Control Disclosures" (2018). FIU Electronic Theses and Dissertations. 3763.

https://digitalcommons.fiu.edu/etd/3763

This work is brought to you for free and open access by the University Graduate School at FIU Digital Commons. It has been accepted for inclusion in FIU Electronic Theses and Dissertations by an authorized administrator of FIU Digital Commons. For more information, please contact dcc@fiu.edu. 


\title{
FLORIDA INTERNATIONAL UNIVERSITY
}

Miami, Florida

\section{OCCURRENCE AND CONSEQUENCES OF \\ SURPRISE INTERNAL CONTROL DISCLOSURES}

\author{
A dissertation submitted in partial fulfillment of the \\ requirements for the degree of \\ DOCTOR OF PHILOSOPHY \\ in \\ BUSINESS ADMINISTRATION
}

by

Hambisa Belina

2018 


\section{To: $\quad$ Dean Joanne Li}

\section{College of Business}

This dissertation, written by Hambisa Belina, and entitled Occurrence and Consequences of Surprise Internal Control Disclosures, having been approved in respect to style and intellectual content, is referred to you for judgment.

We have read this dissertation and recommend that it be approved.

$\begin{array}{r}\hline \text { Abhijit Barua } \\ \hline \text { Suchismita Mishra } \\ \hline \text { Kannan Raghunandan, Co-Major Professor } \\ \hline \text { Dasaratha Rama, Co-Major Professor }\end{array}$

Date of Defense: June 27, 2018

The dissertation of Hambisa Belina is approved.

Dean Joanne Li College of Business

Andres G. Gil President for Research and Economic Development and Dean of the University Graduate School

Florida International University, 2018 


\section{DEDICATION}

In memory of my late son, Sollan H. Belina—aka Sollan the Dreamer, who left fingerprints of grace on our lives. We are grief-stricken by his sudden and untimely death. Even amid our incredible loss and sorrow, our hearts warm by the memory of his free-spirit, his generosity without bounds, his selfless-love, and his enduring joy. 


\section{ACKNOWLEDGMENTS}

I would like to thank the members of my committee: Dr. Abhijit Barua, Dr. Suchismita Mishra, Dr. Kannan Raghunandan and Dr. Dasaratha Rama for their time, support and guidance. I would like to express my gratitude to my co-major professors: Dr. Kannan Raghunandan and Dr. Dasaratha Rama for their gentle support, useful comments and tireless supervision.

I would like to thank my wife, Lemane Kaba, for staying by my side throughout this journey. Without her never-failing sympathy, patience, endurance, encouragement and even sacrifice, this journey wouldn't have been possible. 


\section{ABSTRACT OF THE DISSERTATION \\ OCCURRENCE AND CONSEQUENCES OF SURPRISE INTERNAL CONTROL DISCLOSURES}

by

Hambisa Belina

Florida International University, 2018

Miami, Florida

\section{Professor Kannan Raghunandan, Co-Major Professor \\ Professor Dasaratha Rama, Co-Major Professor}

The Sarbanes-Oxley Act mandates public companies to establish internal control systems and assess their effectiveness. Quarterly reports by all companies and annual reports by companies with less than $\$ 75$ million public float (non-accelerated filers) do not require auditor's attestation while annual reports by companies with $\$ 75$ million or more public float (accelerated filers) do require such auditor attestations. Quarterly reports should provide early warning of any impending material weakness (MW) to be disclosed in subsequent annual filings. This dissertation explores three types of "surprise" MW disclosures - positive, negative and no surprise - and consequences of such surprise disclosures.

In part one, I document the frequency of surprise MW disclosures and internal control factors that are associated with each surprise type by filer status. Results show that 78 (77) percent of accelerated (non-accelerated) MW disclosures are negative surprise MW disclosures during 2004-2016. Entity level MWs are more associated with no-surprise rather than negative or positive surprise MW disclosures. 
In part two, I examine some consequences of surprise MW disclosures. The results show that companies with MW disclosures are more likely to dismiss their auditors and CFOs, and experience more shareholder voting against auditor ratification, compared to companies that issue clean reports. Auditor dismissal and CFO turnover are equally likely at negative and no-surprise MW disclosure companies. However, negative surprise accelerated filer companies' shareholders are more likely to vote against auditor ratification than no-surprise accelerated filer companies.

The third essay investigates the association between MW disclosures and audit fees. The results indicate that there is a significant positive association between audit fees and MW disclosures. Further, the results show that audit fees are higher at no-surprise companies than at negative surprise companies.

The fourth essay focuses on audit report lag. The results indicate that MWs are associated with increased audit report lags, for both accelerated and non-accelerated filers. Further, surprise MW firms are more likely to experience increased audit report lag than no-surprise MW firms.

Overall the results suggest that adverse internal control reports have consequences, and that the consequences vary between surprise and no-surprise MW firms. The results provide relevant empirical evidence to the ongoing debate on the necessity and efficacy of SOX Section 404 requirements. 


\section{TABLE OF CONTENTS}

CHAPTER

PAGE

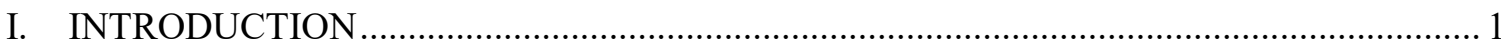

II. SURPRISE MATERIAL WEAKNESS DISCLOSURES: FREQUENCIES AND FACTORS

.

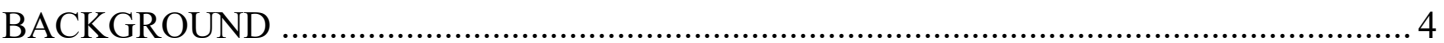

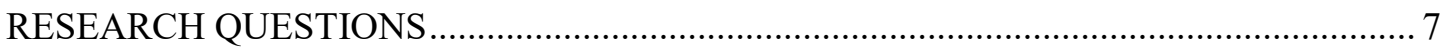

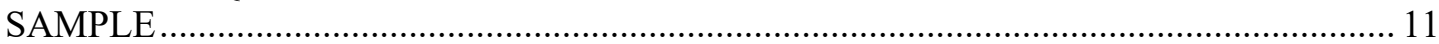

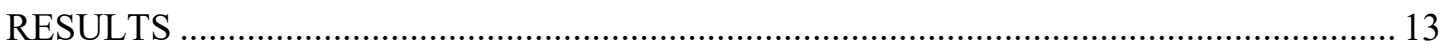

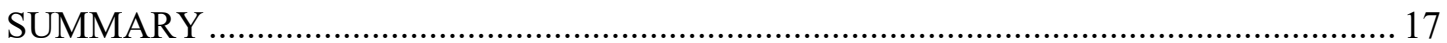

III. SURPRISE MATERIAL WEAKNESS DISCLOSURES AND AUDITOR DISMISSALS, CFO TURNOVER AND AUDITOR RATIFICATION VOTES ………............................... 20

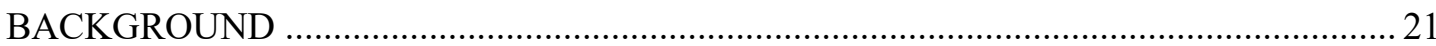

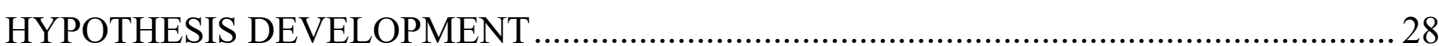

AUDITOR DISMISSALS AFTER SURPRISE MW DISCLOSURES …………………........ 34

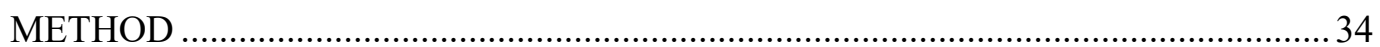

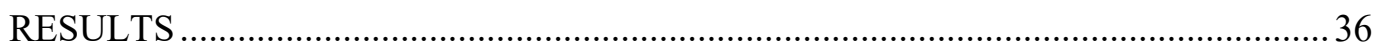

CFO TURNOVER AFTER SURPRISE MW DISCLOSURES .......................................... 41

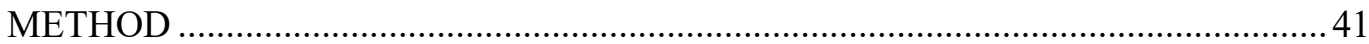

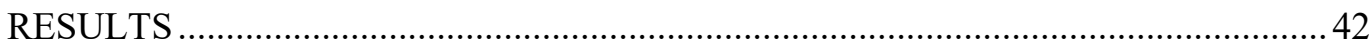

SHAREHOLDER VOTING AFTER SURPRISE MW DISCLOSURES ………………….....46

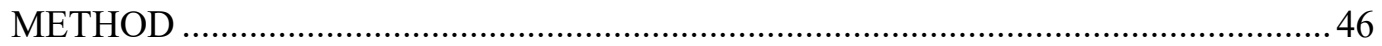

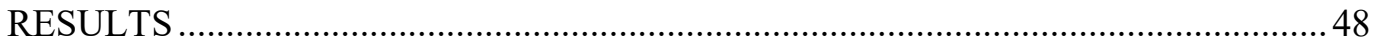

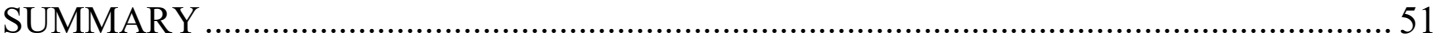

IV. SURPRISE MATERIAL WEAKNESS DISCLOSURES AND AUDIT FEES .......................55

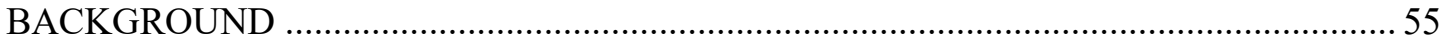

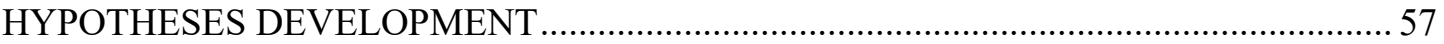

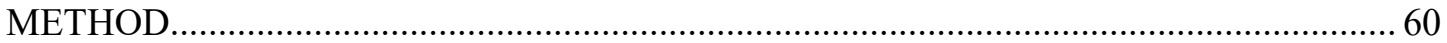

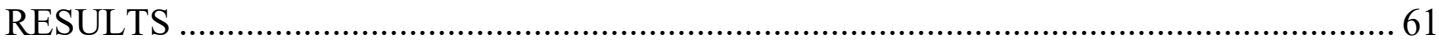

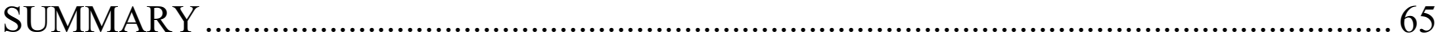

V. SURPRISE MATERIAL WEAKNESS DISCLOSURES AND AUDIT REPORT LAGS....67

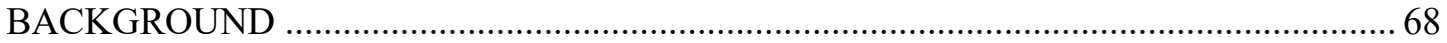

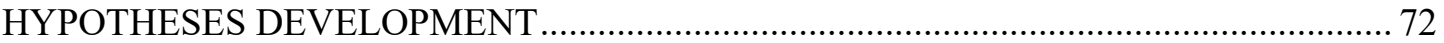

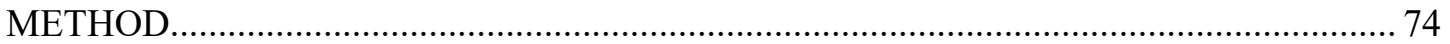

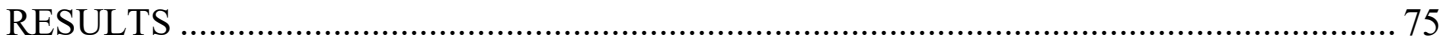

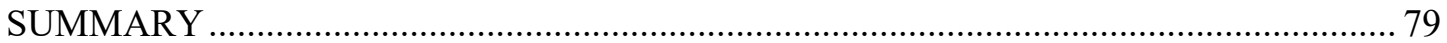

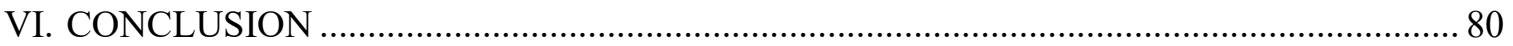

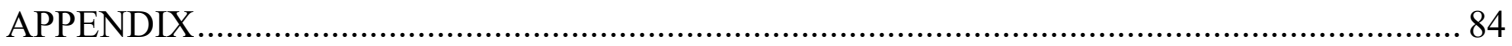

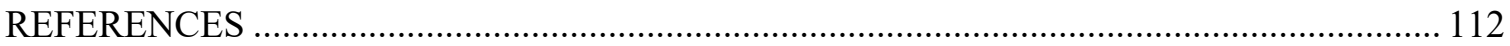

VITA 


\section{LIST OF TABLES}

TABLE

PAGE

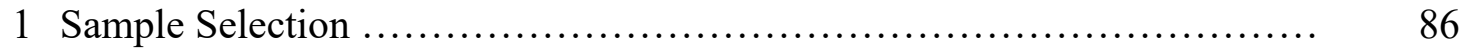

2 Internal Control Factors in SOX Section 404 MW Disclosures: Accelerated Filers .............................................................................

3 Internal Control Factors in SOX Section 404 MW Disclosures: Nonaccelerated Filers.

4 Internal Control Factors in SOX Section 302 MW Disclosures: Accelerated Filers.

5 Internal Control Factors in SOX Section 302 MW Disclosures: NonAccelerated Filers

6 Mean Values - Auditor Dismissals: Accelerated Filers

7 MW Disclosures and Auditor Dismissals: Accelerated Filers

8 Mean Values - Auditor Dismissals: Non-Accelerated Filers

9 MW Disclosures and Auditor Dismissals: Non-Accelerated Filers

10 Mean Values - CFO Turnover: Accelerated Filers

11 Surprise MW Disclosures and CFO Turnover: Accelerated Filers

12 Mean Values - CFO Turnover: Non-Accelerated Filers

13 Surprise MW Disclosures and CFO Turnover: Non-Accelerated Filers

14 Mean Values - Shareholder Auditor Ratification Vote: Accelerated Filers ...

15 Surprise MW Disclosures and Auditor Ratification Vote: Accelerated Filers 
16 Mean Values - Shareholder Auditor Ratification Vote: Non-Accelerated

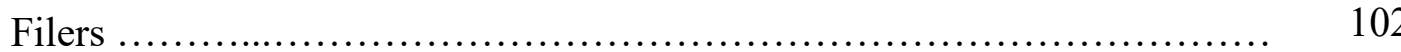

17 Surprise MW Disclosures and Auditor Ratification Vote: Non-Accelerated Filers

18 Mean Values - Audit Fee Analysis: Accelerated Filers

19 Audit Fee Analysis - Accelerated Filers.

20 Mean Values - Audit Fee Analysis: Non-Accelerated Filers

21 Audit Fee Analysis - Non-Accelerated Filers

22 Mean Values - Audit Report Lag: Accelerated Filers

108

23 Audit Report Lag - Accelerated Filers

109

24 Mean Values - Audit Report Lag: Non-Accelerated Filers

25 Audit Report Lag - Non-Accelerated Filers 


\section{INTRODUCTION}

In the aftermath of major accounting scandals at the beginning of this century, the United States Congress enacted "The Public Company Accounting Reform and Investor Protection Act of 2002," also known as Sarbanes-Oxley Act (United States Congress, 2002) (SOX) to restore public trust in the capital market. SOX Section 302 requires that the principal executive officer and the principal financial officer of all public firms certify their firm's quarterly internal control disclosures. Section 404(a) mandates that management document and test the internal control structure and issue a report on the effectiveness of internal controls related to financial reporting. Section 404(b) requires that a registered public accounting firm attest the internal control assessment made by management. Policy makers believed that effective internal control helps companies to provide reliable financial statements that safeguard the company's assets, promotes efficient operations, and comply with laws and regulations.

SOX Section 404 is not yet settled. The Dodd-Frank Act (DFA, 2010) exempted non-accelerated filers from the auditor internal control attestation requirements of SOX Section 404(b); subsequently, Section 103 of the Jumpstart Our Business Startups Act (JOBS, 2012) provided exemption from Section 404(b) requirements of SOX for "emerging growth companies." Legislative efforts to curtail Section 404(b) continue; The latest version of the CHOICE Act, introduced in September 2016 by the Chairman of the House Committee on Financial Services and revised in February 2017, seeks to provide permanent exemption from Section 404(b) of SOX to issuers with market capitalization up to $\$ 500$ million (McKenna, 2017; U.S. House of Representatives, 2017). Thus, Section 
404 of SOX continues to be controversial and legislators continue to seek exemption from the requirements of Section 404 for many smaller public companies.

While Section 404 of SOX has attracted attention from legislators and regulators, Section 302 of SOX also deals with management reporting on internal control. SEC (2003) rules related to the implementation of Section 302 of SOX require that both the CEO and CFO certify about the effectiveness of disclosure controls and about material changes in internal controls over financial reporting. A key point to note is that, while Section 404 applies only for (audited) annual 10-K filings, Section 302 requires certifications in (unaudited) quarterly 10-Q filings.

The SEC (2003) notes that "there is substantial overlap between internal control over financial reporting and disclosure controls and procedures". SEC (2004) states that accelerated filers "carefully consider" whether material weaknesses discovered as part of their Section 404 testing be disclosed under Section 302 in interim periods. Financial statement users view the Section 302 rules as requiring prior disclosure about material weaknesses in Section 302 certifications before their disclosure in Section 404 filings (Glass Lewis \& Co., 2005; Steinberg, 2005).

In this dissertation, I examine the occurrence and consequences of surprise internal control disclosures in four interrelated essays. Specifically, I look at the frequencies, proportion, and consequences of surprise internal control material weakness (MW) disclosures using a sample of 36,627 firm-year observations from fiscal year 2004 through 2016. I define "surprise" MW disclosures as follows: (1) negative surprise when there is SOX 404 MW disclosure at year-end without SOX 302 MW disclosure during the preceding quarters of the same year; (2) positive surprise when there is SOX $302 \mathrm{MW}$ 
disclosure during the preceding quarters of the year but there is a clean SOX 404 report at year-end; and (3) no surprise when there is SOX $302 \mathrm{MW}$ disclosure during the preceding quarters of the year and there is a SOX $404 \mathrm{MW}$ disclosure at the year-end.

This dissertation consists of four essays organized as follows. In Chapter II, I investigate the frequency of surprise MW disclosures, and internal control factors associated with each surprise type by filer status. In Chapter III, I investigate the association between surprise MW disclosures and audit committee (and the board) reaction to such surprise disclosures by examining subsequent auditor dismissal and CFO turnover. Further, I look at the association between surprise disclosures and the reaction by external users of such disclosures by investigating shareholders' auditor ratification vote.

In Chapter IV, I investigate the association between surprise material weakness disclosures and audit fee for accelerated and non-accelerated filers. In Chapter V, I study the association between surprise material weakness disclosure and audit report lags for both accelerated and non-accelerated filers. Finally, in Chapter VI, I end with a summary and discussions of the results of the earlier sections. 


\section{SURPRISE MATERIAL WEAKNESS DISCLOSURES: FREQUENCIES AND FACTORS}

In this part of my dissertation, I examine whether firms provide early warnings in their quarterly Section 302 disclosures about the impending internal control problems to be disclosed at the end of the year in Section 404 reports. The study aims to provide evidence on four interrelated questions. First, what is the proportion of firms with "negative surprise" disclosures in their Section 404 reports? Second, does the likelihood of "negative surprise" in internal control disclosures differ between accelerated and non-accelerated filers? Third, what proportion of firms provide early warnings in their Section 302 disclosures and then issue a clean Section 404 report? Fourth, does the likelihood of such positive "surprise" differ between accelerated and non-accelerated filers?

\section{BACKGROUND}

Research on firms with Internal Control Deficiencies (ICDs) versus without ICDs

As Figure 1, adopted from (Hermanson \& Ye, 2009), shows extant research in the area of internal control compares firms with Internal Control Deficiencies (ICDs) against those without ICDs. Specifically, previous studies compare cells 1, 3, and 5 collectively to cells 2, 4, and 6 collectively (e.g., (Ashbaugh-Skaife, Collins, \& Kinney, 2007); compare cells $1,2,3$, and 5 collectively to cells 4 and 6 collectively, (e.g. (Doyle, Ge, \& McVay, 2007)); compare cells 1 and 2 collectively to cell 4 (e.g., (Krishnan \& Visvanathan, 2007) and compare clean companies to problem companies - full sample of non-accelerated and accelerated filers, non-accelerated filers only, accelerated filers only, and accelerated filers analyzed separately by Section 302 versus Section 404 (Hoitash, Hoitash, \& Bedard, 2009); 
and compare cell 1 to cell 2 for accelerated filers during the fiscal year preceding the initial adverse Section 404 report (Hermanson \& Ye, 2009).

Hermanson \& Ye (2009) find that in the first year of Section 404 reporting, many accelerated filer firms had "surprise" adverse Section 404(b) internal control reports. Such surprise firms file Section 404(b) filings disclosing material weaknesses (MW) in internal control at the end of the year but did not disclose MWs in their quarterly Section 302 filings during the same year. They find that only 27 percent of 451 accelerated filers with an adverse Section 404(b) audit opinion in the first year of Section 404 reporting provided early warning in their Section 302 certifications about such MWs in internal control, in the 10-Qs filed in the previous quarters of the same fiscal year. Moreover, they find that early warning of ICDs are positively associated with the severity and number of material weaknesses, prior earnings restatements, auditor independence and effort, CFO change, the number of institutional investors, and the number of audit committee meetings, and negatively associated with future equity financing activities and $\mathrm{CEO} /$ board chair duality.

Munsif, Raghunandan, \& Rama (2013) extend Hermanson \& Ye (2009) by comparing cell 1 to cell 2 (see Figure 1) for accelerated filers as well as for non-accelerated filers. They find that $43 \%$ and $41 \%$ of accelerated filers with material weaknesses in their Section 404(b) reports disclosed early warning in their Section 302 reports in 2007 and 2008, respectively. Moreover, they find that the proportion of non-accelerated filers with Section 404(a) adverse reports that provided early warning in their Section 302 filings were $20 \%$ and $56 \%$ respectively for 2007 and 2008 . They document that surprise disclosures are less likely for firms with (1) a higher number of MWs, (2) a new CFO, (3) more audit committee members, and (4) more frequent audit committee meetings. They also find that 
there was a significant decrease in the likelihood of non-accelerated filers having a surprise MW disclosure in the second year of Section 404(a) reporting than in the initial year.

Figure 1: Differences from Prior Research on Firms with ICDs versus without ICDs

\begin{tabular}{lcc}
\hline Report & Adverse SOX 302 Disclosures & Clean SOX 302 Disclosures \\
\hline Adverse & 1. internal control weakness at & 2. internal control weakness at \\
SOX 404 & year end; company warned of & year end; company did not \\
& $\begin{array}{l}\text { future 404 ICDs under 302 } \\
\text { "no-surprise" }\end{array}$ & $\begin{array}{l}\text { warn of future 404 ICDs under } \\
\text { Clean SOX }\end{array}$ \\
304 & $\begin{array}{l}\text { 3. interim ICDs were remediated surprise" } \\
\text { before year-end "positive }\end{array}$ & $\begin{array}{l}\text { 4. no internal control weaknesses, } \\
\text { or company concealed interim }\end{array}$ \\
& surprise" & $\begin{array}{l}\text { ICDs and remediated the ICDs } \\
\text { before year-end "clean" }\end{array}$ \\
No SOX 404 & 5. non-accelerated filers & 6. non-accelerated filers \\
\hline
\end{tabular}

The present study compares cells 1 and 2 collectively with cell 4 in the full sample; compares cell 3 with cell 4 in the positive surprise sample; and cell 1 with cell 2 in the negative surprise sample.

The intent of policymakers is that firms provide early warning reports about internal control over financial reporting so that financial statement users may insist on improvements on internal control over financial reporting (PCAOB, 2007). In a Keynote Speech at the 11th Annual Midwestern Financial Reporting Symposium, the then Chief Accountant of the U.S. Securities and Exchange Commission (SEC) stated that:

Our capital markets run on faith and trust that the vast majority of companies present reliable and complete financial data for investment and policy decision-making. Representing to the world that a company has in place an appropriate control system, free of material weaknesses, that gathers, consolidates, and presents financial information strengthens public confidence in our markets and encourages investment 
in our nation's industries. If that's the case, then it's worth it, and it is absolutely critical that we get the internal control requirements right (Nicolaisen, 2004).

The motivation for this study comes from the fact that internal control disclosures by public companies and their auditors continue to be of significant interest to legislators, regulators and academics. To this effect, this study extends Munsif, Raghunandan, \& Rama (2013) and investigates whether firms provide early warnings in their quarterly Section 302 disclosures about the impending internal control problems to be disclosed at the end of the year in Section 404 reports.

\section{RESEARCH QUESTIONS}

\section{Proportion of "Negative Surprise" Internal Controls}

Prior research has identified that the disclosure of internal control problems requires that the deficiencies must exist; that such deficiencies are discovered; and that the deficiencies are correctly classified and judged to be disclosed to the public (AshbaughSkaife et al., 2007; PCAOB, 2007).

During the initial period of internal control disclosures there was substantial uncertainty as what constitutes "material weakness." Such uncertainties might have resulted in management and auditors adopting differing thresholds for classifying internal control deficiencies as "material" and publicly disclose such internal control problems (Hermanson \& Ye, 2009; Munsif et al., 2013; Rice \& Weber, 2012). As management and auditors obtained more experience over a decade of Section 302 and Section 404 reporting, there is greater likelihood that (1) accelerated and non-accelerated filers can identify MWs earlier even without auditor involvement, and/or (2) judgement differences on 
classification of internal control-related issues between clients and auditors would be less pronounced. Thus, the proportion of "surprise" adverse internal control reports during should decrease in the later years of SOX implementation.

Conversely, (Rice \& Weber, 2012) find that the proportion of firms providing early warning about accounting problems that force them to restate their financial statements is decreasing over time despite being subject to outside audit. Due to pressure from the capital market (Richardson, Tuna, \& Wu, 2002) and the complexity of the control environment (Rice \& Weber, 2012), management may be inherently less likely to voluntary disclose MWs and may do so only when the auditor forces the disclosure during the year-end audit either through internal control attestation or the auditing of the financial statements. In either case, there may not be a significant decline in the proportion of "negative surprise" disclosures of MWs in later years Section 404 reporting. Ultimately, this is an empirical issue. Thus, the first research question is:

RQ1 What is the proportion of companies with "negative surprise" $M W$ disclosures in their Section 404 reports during the years 2004 through 2016?

\section{Proportion of "Positive Surprise" Internal Controls}

Section 302 disclosures are unaudited and such disclosures show management's diligence. Non-accelerated filers are not subject to auditor attestation requirements of Section 404(b) and are required to file their internal control reports with only management evaluations of internal control pursuant to Section 404(a). Thus, there is no overriding of management's judgments about when an internal control problem is material and, hence, requires disclosure. Therefore, it is less likely that there would be "positive surprise" MW disclosures of material internal control problems in the case of non-accelerated filers. 
Conversely, there is significant adverse impact to disclosures of MWs under Section 302 (Beneish et al., 2008). Firms that disclose MWs under Section 302 experience abnormally negative forecast revisions and abnormally positive increases in costs of capital after their Section 302 disclosure.

It is expected that as companies become experienced with SOX reporting and have longer time to strengthen internal control infrastructure the likelihood of firms finding and disclosing internal control problems in Section 302 reports will increase. Further, with time, companies' capability to remediate interim ICDs before the year-end is expected to increase. Thus, this study also examines if there are any "positive surprises"- the likelihood of firms that disclose material weaknesses in their quarterly Section 302 disclosures which are remediated during the year yielding clean Section 404 reports at the year-end. Thus, my second research question is:

RQ2 What is the proportion of companies with "positive surprise" (i.e., clean Section 404 reports with Section $302 \mathrm{MW}$ disclosures in earlier quarters) Section 404 reports in the years 2004 through 2016?

"Negative" and "No-surprise" Internal Control Disclosures

One potential explanation for the results in Hermanson \& Ye (2009) and Munsif et al. (2013) is that differences in judgments, what constituted a material weakness that had to be publicly disclosed (as opposed to "significant deficiencies" that were not required to be disclosed), could plausibly explain the spate of "surprise" MW disclosures at the yearend. For example, companies may have classified some internal control problems as "significant deficiencies" (not requiring public disclosure) while auditors may have been more conservative and classified the same as "material" (requiring disclosure). Hence, 
differences between auditors and clients about the classification of internal control problems is a plausible reason for many surprise MW reports in the initial years of Section 404 reporting. If this is the case, the internal control factors (issues) identified in negative surprise and no-surprise MW disclosures should be significantly different and be difficult for management to find and classify as material weaknesses. This leads to the third research question, about the differences in the internal control problems between negative surprise and no surprise MW disclosures.

\section{RQ3 Are the internal control issues in "negative surprise" Section $404 \mathrm{MW}$ disclosures different from those in "no-surprise" MW disclosures?}

\section{"Positive" and "No-surprise" Internal Control Disclosures}

As noted above, positive surprise Section 404 disclosures refer to companies that had disclosed MWs in their Section 302 reports for earlier quarters of the fiscal year but had a clean Section 404 report at the fiscal year-end. In contrast, the no-surprise group of firms disclosed MWs in their Section 302 reports for the earlier quarters but did not remediate such problems before the fiscal year-end and hence had an adverse Section 404 report at the year-end. Thus, both groups of firms had identified MWs earlier in the year, and the difference arises based on whether or not the identified problems had been remediated by the year-end. This provides us the opportunity to compare the types of Section 302 MWs between the two groups. Thus, the fourth research question is:

RQ4 Are the internal control issues in "positive surprise" Section $302 \mathrm{MW}$ disclosures different from those in "no-surprise" MW disclosures? 


\section{SAMPLE}

I obtain SOX Sections 302 and 404 data and audit-related data (audit firm, audit fees, and opinions) from the Audit Analytics database. COMPUSTAT is the source for financial data, while other data are collected from the Securities Exchange Commission (SEC) website. ${ }^{1}$ I begin with management reports on internal control in Audit Analytics for 2004 thorough 2016.

Panel A of Table 1 presents the sample selection. I start with 110,039 accelerated and non-accelerated filer companies with Section 404 reports for the years 2004 through 2016 from the Audit Analytic database. Consistent with prior research, I delete 8,508 foreign companies and 25,656 financial sector companies. Then I delete 33,894 companies

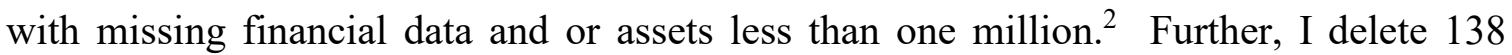
companies that had issued significant deficiency in their Section 302 disclosures and companies with restatements in the third quarter. ${ }^{3}$ I restrict the analysis to companies that did not have an adverse Section 404 report in any of the prior two years, to ensure that my analysis is not contaminated by prior year MW disclosures. Thus, I also delete 2,710 companies that had MW disclosures during the preceding two years. Finally, I delete nonaccelerated filer companies before 2007 since Section 404 became effective for nonaccelerated filers on or after December 15, 2007. My final sample consists of 36,627 companies: 29,134 accelerated and 7,493 non-accelerated filers. I partition the analysis

\footnotetext{
${ }^{1}$ I winsorize all continuous variables at the $1^{\text {st }}$ and $99^{\text {th }}$ percentiles.

2 This is to prevent problems arising from small denominators causing extreme values of financial ratios.

${ }^{3}$ This is to ensure that surprise MW disclosures were not preceded by issues that were indicators of warning during the preceding quarters of the same year. Significant deficiencies could be construed as warning and third quarter restatements might cause the year-end disclosures.
} 
into accelerated and non-accelerated filers. This is because auditor attestation of internal controls is not required for non-accelerated filers.

Panel B of Table 1 presents the breakdown of the accelerated filer companies. 27,988 of the 29,134 accelerated filer companies have clean Section 404 reports, while 1,146 of them have Section $404 \mathrm{MW}$ disclosures. I further partition the 1,146 MW disclosures into 253 "no-surprise" MW companies that issued prior Section 302 MW disclosures during the year; and 893 "surprise" MW companies that did not disclose Section 302 material weaknesses.

Panel C of Table 1 presents the breakdown of the non-accelerated filer companies. 6,749 of the 7,493 non-accelerated filer companies have clean Section 404 reports, while 744 of them have Section 404 MW disclosures. I further partition the $744 \mathrm{MW}$ disclosures into 169 "no-surprise" MW companies that issued Section 302 MW disclosures during the year; and 575 "surprise" MW companies that did not disclose Section 302 material weaknesses.

Panel D of Table 1 provides breakdown of the clean Section 404 companies for both accelerated and non-accelerated filer groups. The table shows that 325 (139) of accelerated (non-accelerated) filer companies with clean Section 404 disclosed MWs in Section 302 filings for the earlier quarters of the same fiscal year.

In this and the following parts of my dissertation, I use the same sample to investigate the research questions and hypotheses developed in each part. Hence, I do not discuss sample selection in each part this dissertation. I partition the sample into three samples as in figure 2 on next page. 
Figure 2: Sample Partition

\begin{tabular}{|c|c|c|c|}
\hline Sample & Description & Accelerated & Non-Accelerated \\
\hline \multirow{2}{*}{ Full } & Section 404 MW vs. Clean & 29,134 & 7.493 \\
\hline & Section 404 & 1,146 vs. 27,988 & 744 vs. 6,749 \\
\hline Clean & Clean Section 404 with \& & 27,988 & 6,749 \\
\hline SOX 404 & without Section $302 \mathrm{MW}$ & 325 vs. 27,663 & 139 vs. 6,610 \\
\hline \multirow{2}{*}{ MW } & Negative Surprise vs No- & 1,146 & 744 \\
\hline & surprise MW Disclosures & 893 vs. 253 & 575 vs. 169 \\
\hline
\end{tabular}

\section{RESULTS}

Frequencies of Negative, Positive and No Surprise MW Disclosures

As seen in Table 1 Panel B, the total number of accelerated filers with an initial adverse Section 404 report in my sample is 1,146 for the years of 2004-2016. Consistent with prior research, I classify a company as having provided prior warning if one or more of the MWs that were disclosed in the Section 404 report was also mentioned in the prior Section 302 report. Table 1 Panel B shows that a total of 253 firms disclose similar internal control problems during prior quarters of the same year as those they later disclose in the year-end Section 404 reports. As noted earlier, I classify these 253 companies as "no surprise" MW firms. The remaining 893 companies are classified as "surprise MW" companies, since they failed to disclose MWs in Section 302 filings for prior quarters of the same fiscal year.

The proportions of accelerated filers with Section 404 MW disclosures during the sample period is 3.9 percent $(1,146$ of 29,134$)$. Considering only the MW companies, 78 percent (893 of 1146) are surprise disclosures. Thus, only 22\% (253 of 1146) year-end 
Section 404 MW disclosures for accelerated filers had issued Section 302 MW during the preceding quarters of the year. The proportion of Section 404 surprise disclosures for accelerated filers are higher $(\mathrm{p}<.05)$ than the initial year disclosures reported in Hermanson and Ye (2009).

As seen in Table 1 Panel C, the total number of non-accelerated filers with an initial adverse Section 404 report in my sample is 744 for the years of 2004-2016. A total of 169 firms disclose similar internal control problems during prior quarters of the same year as those they later disclose in the year-end Section 404 reports. As stated above, I classify these 169 companies as "no surprise" MW firms. The remaining 575 companies are classified as "surprise MW" companies. The proportions of non-accelerated filers with Section 404 MW disclosures during the sample period is 9.9 percent $(744$ of 7,493). Considering only the MW companies, 77 percent (575 of 744) have surprise disclosures. Thus, only 23\% (169 of 744) year-end Section 404 MW disclosures for non-accelerated filers had issued Section $302 \mathrm{MW}$ during the preceding quarters of the same fiscal year. The proportion of Section 404 surprise disclosures for non-accelerated filers are higher $(\mathrm{p}<.001)$ than the initial year disclosures reported in Munsif et al. (2013).

The results from Table 1 Panels B and C taken together show that even after a decade of SOX implementation, 78 (77) percent of accelerated (non-accelerated) filer companies with initial MW disclosures have "negative surprise" MW disclosures. These findings do not support arguments that the regulatory delays and learning processes of managers and auditors, in the initial years of SOX 404 reporting, were the reasons for the high proportion of surprise MWs in the initial years of Section 404 reporting. 
Table 1 Panel D shows that 1.2 percent $(325$ of 27,988$)$ of accelerated filers with clean Section 404 reports disclose MWs in Section 302 reports in preceding quarters of the year; these are "positive surprise" MW firms. The proportion of "positive" MW disclosures of non-accelerated filers $(139$ of 9,749 , or 2.1 percent $)$ is higher $(\mathrm{p}<.0001)$ than that of accelerated filers.

Factors in Negative and No Surprise MW Disclosures

Tables 2 and 3 present the frequency of occurrences of different types of issues for accelerated and non-accelerated filers in Section 404 and Section 302 MW disclosures by "negative surprise" and "no-surprise" categories. In all the tables, I use the disclosure categories as given in Audit Analytics. As shown in Table 2 and 3, there is no difference between negative and no-surprise categories in many of the MW issues suggesting that both groups are equally likely to be affected by the internal control issues.

Table 2 shows the internal control factors that are reported by accelerated filer companies in Section $404 \mathrm{MW}$ disclosures. Documentation related issues and year-end adjustments are typically pervasive and less sudden — and, thus, not a strong explanation for the surprise MW disclosures. As the table shows, no-surprise MWs were more likely $(p<.05)$ to $(1)$ have problems related to the quality and quantity of accounting personnel such as segregation of duties and ethical or compliance issues with personnel, (2) senior management competency, tone, reliability issues, (3) revenue recognition; income statement classification, margin and EPS; and inventory, vendor and cost of sales issues, (4) restatement or non-reliance of company filings, (5) information technology, software, security and access issues, (6) journal entry control, capitalization of expenditures, and 
expense recording issues, and (7) deferred stock-based or executive compensation issues. These are unlikely to have developed suddenly at the year-end, and thus consistent with being more prevalent in no-surprise MWs.

Table 3 presents the types of internal control problems disclosed for nonaccelerated filers by surprise category. As is in Table 2 for accelerated filers, accounting documentation, personnel-related problems, and unspecified FASB/GAAP issues are pervasive for surprise and no-surprise MW disclosing non-accelerated filer companies. Accounting documentation, policy and/or procedures are more likely $(\mathrm{p}<.1)$ at negative surprise MW disclosing non-accelerated filer companies. Segregation of duties/design control (personnel) and expense recording are more likely $(\mathrm{p}<.1)$ at no-surprise MW disclosing non-accelerated filer companies. Internal control problems related to information technology, software, security \& access issues; acquisition, merger, disposal or reorganization issues; depreciation, depletion or amortization issues; and journal entry control issues are more likely $(\mathrm{p}<.05)$ associated with no-surprise MW disclosures whereas material and/or numerous auditor/yearend adjustments are more likely $(\mathrm{p}<.01)$ related to surprise MW disclosing non-accelerated filers. This, again, is consistent with expectations that pervasive problems are more likely to be associated with no-surprise MW disclosures.

Factors in Positive and No Surprise MW Disclosures

Tables 4 and 5 present Section $302 \mathrm{MW}$ issues with mean differences and p-values for "positive surprise" and "no-surprise" accelerated and non-accelerated filer companies, respectively. Both "positive surprise" and "no-surprise' companies have MW disclosures during the prior quarters of the same year. The "positive surprise" groups remediate the 
MW disclosed in Section 302 reports, hence, issue a clean Section 404 report at year-end, while the "no-surprise" group fail to remediate the MWs disclosed in their Section 302 and thus issue Section $404 \mathrm{MW}$ disclosures at year-end.

As shown in Table 4, many pervasive and less sudden issues such as revenue recognition; information technology, software, security \& access; inventory, vendor and cost of sales; and restatement of previous 404 disclosures are more likely $(\mathrm{p}<.05)$ related to no-surprise MW disclosing accelerated filing companies than to "positive surprise" firms.

As shown in Table 5, issues related to unspecified or unidentified or inapplicable FASB/GAAP $(\mathrm{p}<.01)$ and information technology, software, security \& access are more likely $(\mathrm{p}<.05)$ related to no-surprise MW disclosing non-accelerated filer companies. Revenue recognition and deferred, stock-based or executive compensation issues are more likely $(\mathrm{p}<.1)$ at positive surprise than no-surprise MW disclosing non-accelerated filer companies.

\section{SUMMARY}

Section 404 of SOX continues to be controversial, with legislators seeking to increase the number of SEC registrants that would be exempt from the auditor attestation requirements of Section 404(b). The rationale underlying such efforts is that financial statement users can receive adequate information about internal controls without the costs associated with auditor involvement in such reporting. However, critics note that auditor involvement is essential for the timely disclosure of internal control problems. In this study, I provide some relevant empirical evidence for the debate surrounding Section 404 of SOX. 
Two prior studies, examining initial years of Section 404 reporting by accelerated filers (Hermanson \& Ye, 2009) and non-accelerated filers (Munsif et al., 2013), find that that many companies that disclosed material weaknesses in internal controls in their annual Section 404 reports did not provide early warning of such problems in their Section 302 certifications for earlier quarters of the same fiscal year. Initial year implementation issues, including differences in expectations of managers and auditors during the learning phase of Section 404, offer one explanation for such surprise MW disclosures reported in the two prior studies. I extend such research by examining surprise MW disclosures during 20042016.

I find that 893 of the 1,146 (575 of 744) MW disclosures by accelerated (nonaccelerated) filers are surprise MW disclosures. The proportions of MW disclosures that were surprises are higher in my study, for both accelerated and non-accelerated filers, compared to the two prior studies noted above. Thus, the explanation offered for the findings in the two prior studies - namely, learning and initial-year implementation problems - cannot explain the high proportions of surprise MW disclosures during 20042016, especially during the later years of SOX implementation. I find that such surprise MW disclosures are not driven by financial restatements during the fourth quarter, since I have excluded all restatements after in the third quarter.

I find that a small number of clean Section 404 reports with 302 MW disclosures during the prior quarters of the year. The results show that the proportion of "positive" surprise disclosures of non-accelerated filers is higher than that of accelerated filers.

I also find that Section 404 internal control problem factors in negative and nosurprise MW disclosures are generally similar except that no-surprise MW disclosures 
exhibit more personnel and systematic issues for both the accelerated and non-accelerated filer groups. Further, section 302 disclosure control problem factors in positive and nosurprise Section $404 \mathrm{MW}$ disclosures are generally similar, except that no-surprise MW disclosures exhibit more personnel and systematic issues for both the accelerated and nonaccelerated filer groups. 


\section{SURPRISE MATERIAL WEAKNESS DISCLOSURES AND AUDITOR DISMISSALS, CFO TURNOVER AND AUDITOR RATIFICATION VOTES}

In this part, I examine some consequences of "surprise" Section 404 internal control material weakness (MW) disclosures by U.S. public companies. Hermanson \& Ye (2009) refer to MW disclosures in Section 404 reports at the year-end without a prior MW disclosure in Section 302 reports for the prior quarters of the same fiscal year as "surprise" MW disclosures. I refer to such disclosures as "negative surprise" MW disclosures; further, I refer to MW disclosures in Section 302 reports during the first three quarters of the year without year-end Section 404 MW disclosures as "positive surprise" disclosures.

Reports from the PCAOB (Franzel, 2016) indicate that adverse Section 404 opinions have increased from 3.4 percent in 2010 to 6 percent in 2015. The same report also highlights that "consistent with prior years, the vast majority of public companies and other issuers with restatements had 'clean' ICFR opinion in that same fiscal year." Motivation for my study comes from this continued trend and the continuing interest of legislators about the internal control reporting requirements pursuant to Section 404 of SOX (McKenna, 2017).

In this study, I examine the consequences of surprise MW disclosures. Specifically, I investigate auditor dismissal, CFO turnover, and shareholder vote against auditor ratification after surprise MW disclosures. I hypothesize that auditor dismissal; CFO turnover; and adverse auditor ratification votes would be higher for companies that disclose material weakness in internal control over financial reporting. I examine if poor internal control quality due to surprise disclosures has differential impact on auditor change, CFO 
change and shareholders' dissatisfaction of the auditor subsequent to surprise MW disclosures.

\section{BACKGROUND}

Prior Research on the Consequences of Material Weakness

Many prior studies have examined the consequences associated with Section 404 MW disclosures. I briefly summarize the results from such studies below.

Gupta \& Nayar (2007) use a sample of 90 firms from November 2003 to July 2004 to examine whether internal control weakness disclosures convey valuation-relevant information to the US equity markets. They find that internal control weakness disclosures are associated with a negative stock price reaction. Hammersley, Myers, \& Shakespeare (2008) use a sample of 358 Section 302 observation from November 2003 to January 2005 to examine the stock price reaction to management's disclosure of internal control. They find that returns are significantly less negative if management concludes that internal controls are effective despite the presence of an internal control weakness and weakly less negative when the firm engages a Big Four auditor versus a smaller auditor. They also find that returns are significantly more negative when the internal control weaknesses are less auditable and when disclosures about them are vague.

Ashbaugh-Skaife, Collins, Kinney, \& LaFond (2008) use 1,281 Section 404 MW companies and 6,497 Section 302 reports with and without Section 302 MW disclosures for 2003-2005 and investigate the effect of internal control weaknesses on accrual quality. They find that companies with internal control material weaknesses have lower quality accruals. Chan, Farrell, \& Lee (2008) examine if firms reporting material internal control 
weaknesses under Section 404 have more earnings management compared to other firms using a sample of 1,057. They find mild evidence that there are more positive and absolute discretionary accruals for firms reporting material internal control weaknesses than for other firms.

Feng, Li, \& McVay (2009) examine the relation between internal control quality and the accuracy of management guidance using 2,994 Section 404 reports from 2004 to 2006. They find that firms disclosing ineffective internal controls have significantly more negative changes in return on assets suggesting that weak internal controls contribute to erroneous internal management reports and thereby larger management forecast errors.

Dhaliwal, Hogan, Trezevant, \& Wilkins (2011) use 577 firm years from 2004-2006 to examine the relationship between internal control weakness and cost of debt. They find marginal support for the hypothesis that weak internal control leads to higher cost of debt. Costello \&Wittenberg-Moerman (2011) use 2,828 loans matched to Section 302 material weakness reports from 2002-2008 to examine the effect of financial reporting quality on the trade-off between monitoring mechanisms used by lenders. They find that lenders decrease their use of financial covenants and financial-ratio-based performance pricing provisions and substitute them with alternatives, such as price and security protections and credit-rating-based performance pricing provisions for companies that disclosing material weakness in internal control. Kim, Song, \& Zhang, (2011), use a sample of 1,363 borrowing firms that disclosed internal control weaknesses under Section 404 and 3,164 loan facilities, to compare features of loan contracts between firms with MW and those without MW. They find that (1) the loan spread is higher for MW firms than for non-MW firms by about 28 basis points; (2) firms with more severe, company-level MW pay 
significantly higher loan rates than those with less severe, account-level MW; (3) lenders impose tighter non-price terms on firms with MW than on those without MW; and (4) fewer lenders are attracted to loan contracts involving firms with MW.

Rice, Weber, \& $\mathrm{Wu}$ (2015) examine various penalties that could serve as enforcement mechanisms for Section 404. They use a sample of 659 restatement observation, where 134 of them had Section 404 MW disclosures. They find no evidence that penalties are more likely for firms, managers, or auditors that fail to report existing control weaknesses. Instead, class action lawsuits, management turnover, and auditor turnover are all more likely in the wake of a restatement when control weaknesses had previously been reported.

Feng, Li, McVay, \& Skaife (2015) examine the association between inventoryrelated MWs and firms' inventory management using 8,953 observations from 2004-2009 in Audit Analytics. The authors find that firms with inventory-related MWs have systematically lower inventory turnover ratios and are more likely to report inventory impairments relative to firms with effective internal control over financial reporting.

Sun (2016) uses 16,555 firm years from 2004-2012 and examines whether firm investment level is associated with the disclosure of MWs. She finds that MW firms have significantly lower investment than firms that receive clean opinions.

All of the above studies examine the for-profit sector. In the non-profit sector, Petrovits, Shakespeare, \& Shih (2011) examine the causes and consequences of internal control deficiencies in the nonprofit sector using a sample of 27,495 public charities from 1999 to 2007. They find that the disclosure of weak internal controls over financial 
reporting is negatively associated with subsequent donor support received and government grants.

In summary, prior research shows that there are a variety of negative consequences associated with MW disclosures.

Prior Research on Surprise Material Weakness Disclosures

As noted in the prior chapter, Hermanson \& Ye (2009) use a sample of 451 accelerated filers to examine if the companies have provided early warning in their Section 302 reports during the three quarters of the same year. They find that: (1) management is more likely to provide early warning about more severe internal control deficiencies (ICDs), (2) management's desire to secure future equity financing may result that some ICDs be concealed, and (3) that external auditor plays important role in the early warning of ICDs. They state that "providing early warning of ICDs under Section 302 results in more informative reporting to investors." However, they find that only 27 percent of the 451 accelerated filers that disclosed MWs in the initial year of Section 404 reporting had provided early warning of such MWs in quarterly Section 302 certifications before the fiscal year end. They extrapolate their findings to non-accelerated filers and note that, in the absence of auditor involvement in the internal control reporting process, they "seriously question whether market participants are fully informed about the effectiveness of many smaller companies' controls."

Munsif et al. (2013) use a sample 198 (105) accelerated and 305 (296) nonaccelerated filers in 2007 (2008) to examine MW disclosures by accelerated and nonaccelerated filers based on the assumption that the three necessary conditions of existence, 
discovery and classification of material weaknesses can differ between accelerated and non-accelerated filers. They find that majority of the MW disclosures by accelerated filers were "surprise" MW disclosures. They also find that, in the initial two years of compliance with Section 404(a) of SOX, a majority of non-accelerated filers also had surprise MW disclosures. Specifically, they find that the proportion of management reports disclosing MWs in Section 302 increased from $20 \%$ in the first year to $56 \%$ in the second year for non-accelerated filers. Furthermore, they find that early warning is more likely for firms with (1) a higher number of MWs, (2) a new CFO, (3) more audit committee members, and (4) more frequent audit committee meetings.

Related Research on Internal Control Problems and Auditor Dismissals

Ettredge, Li, \& Scholz (2007) examine the relationship between higher audit fees and auditor dismissals using a sample of 428 dismissal and 4,516 no-switch observations from 2004. They find that clients paying higher fees are more likely to dismiss their auditors and that dismissals are associated with smaller companies, companies with goingconcern reports, and companies that later reported material weaknesses in their internal controls.

Ettredge, Heintz, Li, \& Scholz (2011) use a sample of 13,772 Section 404 reports from 2005 to 2008 to investigate whether adverse ICFR opinions are associated with a greater likelihood of subsequent auditor dismissals. They hypothesize that audit committees are more likely to dismiss incumbent auditors after receiving adverse Section 404 opinions than after receiving clean opinions. Using a logistic regression, they find a positive association between adverse Section 404 opinion and auditor dismissal for all 
years they studied indicating that when a firm receives an adverse ICFR opinion, the audit committee is more likely to dismiss the auditors. The authors conclude that their results indicate that internal control material weakness is a new, important, and perhaps enduring determinant of auditor dismissals.

Hennes, Leone, \& Miller (2014) examine the conditions under which financial restatements lead corporate boards to dismiss external auditors and how the market responds to those dismissal announcements using a sample of 2,036 restatements obtained from Audit Analytics (2006-2010) and U.S. General Accounting Office (1997-2006). They find that auditors are more likely to be dismissed after more severe restatements but that the severity effect is primarily attributable to the dismissal of non-Big 4 auditors rather than Big 4 auditors.

\section{Related Research on CFO Turnover}

There is an extensive literature on executive turnover. In this section, I briefly discuss research related to CFO turnover in companies with financial reporting problems, including restatements and internal control problems.

Desai, Hogan, \& Wilkins (2006) investigate the reputational penalties to managers of firms announcing earnings restatements using 169 restament observation from U.S. General Accounting Office (GAO) for 1997 and 1998. They find that 60 percent of restating firms experience a turnover of at least one top manager within 24 months of the restatement compared to only 35 percent among age-, size-, and industry-matched control firms without a restatement. 
Dao, Huang, Chen, \& Huang (2014) using a sample of 1,485 firm-year observations that filed financial restatements in 2004 and 2005, examine whether firms replacing management after an initial restatement are more likely to experience subsequent restatements than those without management turnover. Their results suggest that management turnover may not help firms to remediate their financial reporting problems; instead, it is the change to a new management that leads to a higher probability of firms having lower earnings quality.

Agrawal \& Cooper (2017) examine the consequences of accounting scandals to top management, top financial officers and outside auditors using a sample of 518 U.S. public companies that announced earnings-decreasing restatements during 1997-2002 and an industry-size matched sample of control firms. After controlling for other determinants of management turnover, they find strong evidence of greater turnover of chief executive officers (CEOs) and chief financial officers (CFOs) of restating firms compared to the control sample.

Li, Sun, \& Ettredge (2010) use a sample of 2,478 companies: 416 receiving adverse SOX 404 opinions and 2,062 receiving clean SOX 404 opinions from 2005. They test the hypothesis that a CFO's turnover is positively associated with a company's prior receipt of an adverse SOX 404 opinion. Their results show that adverse SOX 404 opinion recipients experience more CFO turnover in 2005 as boards seek to improve the perceived credibility of their financial reporting.

Johnstone, Li, \& Rupley (2011) use a sample of 4,335 Section 404 reports from 2004 to 2007 to investigate the association between MWs and board, audit committee and top management turnover. They find a positive association between disclosure of MWs 
and subsequent turnover of members of boards of directors, audit committees, and top management, including the CFO. Wang \& Huang (2013) using a sample of 288 observations (114 with internal control weakness and 174 control cases) investigate the association between CFO turnover and internal controls and find that companies with deficient internal controls are more likely to terminate their CFOs following financial restatements.

\section{HYPOTHESIS DEVELOPMENT}

Prior research shows that the majority of the companies reporting MWs in their SOX 404 opinions had "surprise" MW disclosures. As discussed in part one, I find that such surprise MW disclosures continue to be prevalent through the entire post-SOX period (2004-2016). Why do such surprise disclosures of MWs happen, even a decade after SOX? This question is relevant, in light of the on-going legislative efforts to exempt more public companies from the requirements of Section 404(b) of SOX and since "providing early warning of ICDs [internal control deficiencies] under Section 302 results in more informative reporting to investors" (Hermanson \& Ye, 2009). One possible explanation could be that surprise MW disclosures have no significant consequences to those in charge of making or auditing such disclosure decisions, namely CFOs and external auditors.

Munsif et al. $(2013,187)$ allude to this issue and note the following as a possible

future research question: What are the consequences for firms that provide "surprise" disclosures about internal control problems, and to what extent are such consequences different compared to firms that do provide early warning about internal control problems? I address the above question in this part of my dissertation. 
As noted above, prior studies show that there are adverse consequences to both auditors and CFOs following MW disclosures (Ettredge et al., 2011; Ettredge et al., 2007; Johnstone et al., 2011; Li et al., 2010; Wang \& Huang, 2013). Auditor dismissal is costly in terms of incremental managerial time and start-up fees paid to a new auditor for training and review or re-audit of prior years (AICPA, 1978; De Angelo, 1981; Beattie \& Fearnley, 1995). With longer tenure, auditors gain firm-specific knowledge and experience which makes changing auditors hard since clients' fear of losing firm-specific expertise and efficiency developed by the incumbent auditor (Beck \& Wu, 2006; Myers, Myers, \& Omer, 2003). The expertise of the incumbent auditor becomes more valuable as the size and complexity of a firm's operations increase. Prior studies also show that executives possess firm-specific human capital which makes them not easily replaceable (Leone \& Liu, 2010; Villalonga \& Amit, 2006). Start-up costs and availability of acceptable replacement would become increasingly constraining. Consideration of the cost of switching is likely to affect the probability of auditor dismissal and CFO turnover after surprise MW disclosures.

Audit committees have a significant role in the dismissals of auditors and CFOs. ${ }^{4}$ If audit committees are concerned about failures to disclose the MW promptly, then auditor and/or CFO turnover should be more likely after "surprise" MW disclosures than after nosurprise MW disclosures. However, if auditors and CFOs inform audit committees about the internal control problems during the fiscal year, the fact that the problem is classified as a "material weakness" at the year-end—necessitating public disclosure-may not be

\footnotetext{
${ }^{4}$ Section 301 of SOX explicitly provides audit committees with the authority to hire and compensate the external auditor. In addition, given the role of the CFO in the financial reporting process, audit committees are typically involved in decisions to dismiss the CFO.
} 
viewed as sufficient ground by itself to dismiss the auditor or the CFO. This is because decisions about whether a given problem is a "significant deficiency" that requires no public disclosure versus a "material weakness" that required public disclosure are inherently judgmental and can vary over time. This leads to my first set of hypotheses:

Hla: Section $404 \mathrm{MW}$ disclosure is positively associated with auditor dismissal and CFO turnover.

H1b: The likelihood of auditor dismissal and CFO turnover would be higher for companies with Section 302 MW but positive-surprise Section 404 disclosures when compared to companies with clean Sections 302 and 404 disclosures.

H1c: The likelihood of auditor dismissal and CFO turnover is the same for "surprise" and "no-surprise" Section $404 \mathrm{MW}$ disclosures.

Prior Research on Shareholder Voting on Auditor Ratification

Raghunandan (2003) investigates the association between shareholders vote against or abstaining from ratification of the external auditor and the level of the non-audit fee paid to the external auditor using 172 of the Fortune 1000 companies. He finds that the proportion of shareholders voting against or abstaining from ratification of the external auditor is positively associated with the level of the non-audit fee ratio.

Mishra, Raghunandan, \& Rama (2005) examine the relation between shareholder ratification votes during 2003 using 248 of the S\&P 1500 firms and non-audit services (NAS) fees. They find positive association between shareholder vote against auditor ratification and certain types of non-audit fees (tax fee and other fees), but not with auditrelated NAS fees. 
Dao, Mishra, \& Raghunandan (2008) use a sample of 635 companies to examine the association between shareholder votes on auditor ratification and the length of the auditor-client relationship. They find that shareholder votes against (or abstaining from) auditor ratification are positively correlated with auditor tenure suggesting that shareholders view long auditor tenure as adversely affecting audit quality.

Using a sample of 240 companies with adverse internal control opinions and 240 matched "clean" companies in their first year of Section 404 compliance, Hermanson, Krishnan, \& Ye (2009) examine shareholders' dissatisfaction with auditors that have issued adverse internal control opinions in the first year of the Section 404 implementation process. They find a significant positive interaction between restatement and companylevel material weakness - company-level material weaknesses have a greater effect on shareholder dissatisfaction when there has been a restatement. They also find that, when there is no restatement, shareholders are less likely to vote for auditor ratification if the company received an adverse Section 404 internal control opinion because of noncompany-level material weaknesses.

Hermanson, Rama, \& Ye (2017) use 104 instances of shareholder proposal to restrict non-audit service purchases by public companies from their independent auditors. Using a sample of 51 instances of shareholder vote on proposals seeking to restrict NAS purchases they examine the association between shareholder votes against the purchase of non-audit services and non-audit fee. They find subsequent reduction in the non-audit fee ratio is positively related to the magnitude of the proportion of votes in favor of the shareholder proposal to restrict non-audit fee purchase. 
Using a sample of 6,621 firm-year observation with auditor ratification vote, Tanyi \& Roland (2017) investigate the association between the proportion of shareholder votes against auditor ratification and investors' perception of the auditor-client relationship. They find that lower shareholder approval of the auditor is associated with a negative market reaction to the $8-\mathrm{K}$ announcement of the auditor ratification vote.

Cunningham (2017) uses a sample of 9,003 observation in the Russell 3000 from 2009 to 2012, examines the association between shareholder votes against auditor ratification and proxy advisors' role. She finds that proxy advisors have a statistically significant influence over shareholder voting outcomes when they recommend against auditor ratification.

Barua et al. (2017) use a sample of 12,664 company years during 2011-2014 to examine the association between shareholder votes on auditor ratification and subsequent auditor dismissals. They find that subsequent auditor dismissals become more likely with increases in the proportion of shareholders not ratifying the auditor.

\section{Shareholder Voting After Surprise MW Disclosures}

Auditor dismissal and CFO turnover due to internal control problems is within the authority of the auditor committee (i.e., board of directors). In contrast, outside financial statement users are unlikely to be aware of the underlying internal control problems within a company. Hence, such financial statement users may be more likely to react adversely to surprise MW disclosures than to no-surprise MW disclosures.

In this study, I focus on one measure of investor reaction to financial reporting quality. Shareholder voting on auditor ratification is an issue that has received significant 
interest from regulators in recent years (Brown, 2012; Mayhew, 2017). Prior research shows that MW opinions are associated with shareholder voting related to auditor ratification (Hermanson et al., 2009). More generally, studies show that perceptions about audit quality are reflected in shareholder votes related to auditor ratification (Dao et al., 2008; Raghunandan, 2003; P. N. Tanyi \& Roland, 2017). I expect that shareholder dissatisfaction, as measured by shareholder voting on auditor ratification, would differ for companies with and without surprise MW disclosures.

There are two differing arguments about how surprise MW disclosures would affect shareholder voting on auditor ratification. One view is that a surprise MW disclosure suggests that managers did not disclose the MW prior to the fiscal year-end-because of a lack of ability to detect or unwillingness to disclose — but the auditor involvement in yearend testing is associated with such disclosure. If shareholders attribute such MW disclosure to either the superior detection capability of the auditor and/or the independence of the auditor to force managers to disclose the MW, then shareholders should be happier (or, less dissatisfied) with the auditor after a surprise MW disclosure compared to a no-surprise MW disclosure.

A counter-argument, noted by Hermanson, Krishnan, \& Ye (2009), is that "shareholders may blame the auditor for being partly responsible for the existence of material weaknesses (i.e., low audit quality)." ${ }^{5}$ Further, even though 10-Q filings to the SEC are unaudited, the SEC has required since 2000 that auditors review such quarterly

\footnotetext{
${ }^{5}$ Sainty et al. (2002) suggest that shareholders are more likely to vote against auditor ratification when there is an "undesirable" audit report; these authors find that shareholder dissatisfaction is higher in the presence of a going-concern modified audit opinion.
} 
filings; hence, investors may assign blame to the auditor for not ensuring early disclosure of the internal control problems in quarterly filings that leads to a surprise MW disclosure after the fiscal year-end. Under this view, shareholder voting against the auditor would be higher for the surprise-MW disclosures. Ex-ante, it is not clear which of the above two effects would dominate; ultimately, this is an empirical issue. Thus, my second set of hypotheses is:

H2a: Shareholder votes not ratifying the auditor is higher for companies with Section 404 MW disclosure than for companies without Section 404 MW disclosure.

H2b: Shareholder votes not ratifying the auditor would be higher for companies with Section 302 MW but with positive-surprise Section 404 disclosures when compared to companies with clean Sections 302 and 404 disclosures.

H2c: Shareholder votes not ratifying the auditor would not be different for companies with negative surprise Section $404 \mathrm{MW}$ disclosure when compared to companies with no-surprise Section $404 \mathrm{MW}$ disclosure.

\section{AUDITOR DISMISSALS AFTER SURPRISE MW DISCLOSURES METHOD}

I use a logistic regression model to examine the association between subsequent auditor dismissals and (a) Section 404 disclosures of MWs compared to clean Section 404 reports, (b) Section 302 disclosures of MWs compared to clean Section 302 reports for clean Section 404 reports, and (c) negative surprise vs. no surprise MW disclosures. My regression model controls for other factors that are associated with auditor changes. Based on prior studies (Barua et al., 2017; Carcello \& Neal, 2003; Ettredge et al., 2011; Ettredge 
et al., 2007; Hennes et al., 2014) I control for financial, auditor, and executive characteristics shown to be associated with auditor dismissals.

The logistic regression model is:

$$
\begin{aligned}
A U D I S= & \alpha_{0}+\alpha_{1} * M W(P S U R P / S U R P)+\alpha_{2} * L N T A+\alpha_{3} * L E V+\alpha_{4} * R O A+ \\
& \alpha_{5} * B M+\alpha_{6} * G R O W T H+\alpha_{7} * L O S S+\alpha_{8} * G C+\alpha_{9} * B I G 4+ \\
& \alpha_{10} * N E W C E O+\alpha_{11} * N E W C F O+\alpha_{12} * L N T E N+\alpha_{13} * R E S T+ \\
& \text { year }+ \text { industry }+ \text { error }
\end{aligned}
$$

The dependent variable in the above model, $A U D I S$, equals 1 if there is an auditor dismissal within one-year of a MW disclosure and 0 otherwise. I first use the full-sample and examine the difference between companies with clean Section 404 opinions and companies with Section 404 MW disclosures: the variable of interest here is $M W$, which equals 1 for companies with MW disclosures and 0 otherwise. In the second regression, the sample includes companies with clean Section 404 reports: the variable of interest here is PSURP which equals 1 if there is Section $302 \mathrm{MW}$ disclosure during the preceding quarters of the year and 0 if there is no Section $302 \mathrm{MW}$ disclosure. In the third regression, the sample includes only the MW companies: the variable of interest here is SURP which equals 1 if there is a negative surprise MW disclosure and 0 if there is no-surprise MW disclosure. All the other variables are defined in the appendix. I winsorize continuous variables at the 1st and the 99th percentiles. The data selection is presented in Table 1. 


\section{RESULTS}

Accelerated Filers

Table 6 presents the mean differences between companies with Section 404 MW disclosures and clean Section 404 opinions, clean Section 404 firms with and without prior Section 302 MW disclosures, and negative surprise and no-surprise MW disclosures for accelerated filers. Consistent with prior research, I find that companies with Section 404 MW disclosures, when compared to companies with clean Section 404 reports, are (a) smaller, (b) have worse financial performance and are in worse financial condition, (c) more likely to dismiss its external auditor, (d) more likely to receive going concern opinion, (e) less likely to be audited by the Big 4, (f) more likely to have an auditor with less tenure, and (g) more likely to have restatements. Table 6 also shows that in the subset of companies with a clean Section 404 report, companies with Section 302 MW disclosures, when compared to companies with clean Section 302 reports, are (a) smaller, (b) have worse financial performance and are in worse financial condition, (c) more likely to have restatements in the last three years and (d) more likely to dismiss their auditors. Finally, when considering only the group of Section $404 \mathrm{MW}$ companies, the mean values of the control variables generally do not differ based on the "surprise" status for negative surprise and no-surprise group, except that negative surprise companies are (a) likely to have lower leveraged, (b) less likely to have going concern opinion, (c) less likely to have a new CFO and (d) less likely to have had restatements in the last three years, than the no-surprise companies.

The first $2 \times 2$ table of Panel A of Table 7, shows that 134 of 1146 accelerated filer companies with MW disclosures (11.7 percent) dismissed the auditor within the subsequent 
year. In contrast, 927 of 27,988 accelerated filer companies (3.3 percent) with clean Section 404 opinions dismissed the incumbent auditor within one year after the MW disclosure. The difference is statistically significant $(\mathrm{p}<.0001)$. The second $2 \times 2$ table in Panel A of Table 7 shows that 23 of 325 accelerated filer companies with a positive-surprise MW disclosure (7.1 percent) dismissed the incumbent auditor within one year after the end of the year. In the control group, 904 of 27,663 accelerated filer companies (3.3 percent) dismissed the auditor within one year. The difference is statistically significant $(\mathrm{p}<.001)$. The last $2 \times 2$ table in Panel A of Table 7 shows that 104 of 893 accelerated filer companies (11.7 percent) dismissed the auditor within one year in the negative surprise MW group. In the no-surprise group, 30 of 253 accelerated filer companies (11.9 percent) dismissed the incumbent auditor within one year after Section $404 \mathrm{MW}$ disclosure. The difference is not significant.

Panel B of Table 7 provides the results from the logistic regression models. Consistent with prior research, the MW variable is positive and significant in the first model. Thus, accelerated filer companies with an MW disclosure are more likely subsequently to dismiss the auditor when compared to companies with clean Section 404 opinions. Panel B of Table 7 also shows the second regression - a sample of clean Section 404 reports with and without prior Section 302 MW disclosure. The PSURP variable is positive and significant in the second regression. Thus, accelerated filer companies with Section 302 MW disclosure are more likely subsequently to dismiss the auditor when compared with accelerated filer companies with clean Section 302 reports. In the third regression in Panel B of Table 7, using only the MW sample, the variable of interest 
$(S U R P)$ is not significant. Thus, negative- and no-surprise Section 404 MW disclosure accelerated filer companies are equally likely subsequently to dismiss the auditor.

Non-Accelerated Filers

Table 8 presents the mean differences between companies with MW SOX 404 disclosures and clean SOX 404 opinions, clean SOX 404 firms with and without prior SOX $302 \mathrm{MW}$ disclosures, and surprise and no-surprise MW disclosures, for non-accelerated filers. Consistent with prior research, I find that companies with SOX MW disclosures, when compared to companies with clean SOX 404 reports, are (a) smaller, (b) have worse financial performance and are in worse financial condition, (c) more likely to dismiss external auditor, (d) more likely to receive going concern opinion, (e) less likely to be audited by the Big 4, (f) more likely to have an auditor with less tenure, and (g) more likely to have restatements. Table 8 also shows that, in the clean SOX 404 sample, companies with Section 302 MW disclosures compared to companies with clean SOX 302 reports, are (a) smaller, (b) have worse financial performance and are in worse financial condition, (c) more likely to have restatements in the last three years and (d) more likely to dismiss their auditors. Finally, considering only the group of Section $404 \mathrm{MW}$ firms, the mean values of the control variables generally do not differ between the negative surprise and no-surprise groups, except that no-surprise companies are more likely to have had restatements in the last three years than negative surprise companies.

The first $2 \times 2$ table, on the left-hand side of Table 9, shows that 89 of the 744 companies with MW disclosures (12.0 percent) dismissed the incumbent auditor within one year after the MW disclosure; in contrast, 388 of the 6,748 non-accelerated filer 
companies (5.8 percent) with clean Section 404 opinions dismissed the auditor within the subsequent one year. The difference is statistically significant $(\mathrm{p}<.0001)$. The second $2 \mathrm{x} 2$ table of Table 9 also shows the proportion of auditor dismissal for the clean SOX 404 sample. 22 of the 139 of non-accelerated filer companies with Section $302 \mathrm{MW}$ disclosure (15.8 percent) dismissed the incumbent auditor within one year after the end of the year. In the clean Section 302 report, 366 of the 6509 companies (5.5 percent) dismissed the auditor within one year. The difference is statistically significant $(\mathrm{p}<.0001)$. The third $2 \mathrm{x} 2$ table of Table 9 also shows that 67 of the 575 surprise MW companies (11.7 percent) dismissed the auditor within one year. Whereas, 22 of the 169 no-surprise MW companies (13.0 percent) dismissed the incumbent auditor within one year after the MW disclosure. The difference is not significant.

The first regression in Panel B of Table 9 provides the results from the logistic regression models for the non-accelerated filer sample. Consistent with prior research, the MW variable is positive and significant in the first model. Thus, non-accelerated filer companies with an MW disclosure are more likely subsequently to dismiss the auditor when compared to non-accelerated filer companies with clean Section 404 opinions. The second regression in Panel B of Table 9 uses the sample of clean Section 404 reports with and without prior Section $302 \mathrm{MW}$ disclosure. The PSURP variable is positive and significant in the second regression. Thus, non-accelerated filer companies with Section 302 MW disclosure are more likely subsequently to dismiss the auditor when compared with companies with clean Section 302 reports. In contrast, the third regression in Panel B of Table 9 shows that the variable of interest $(S U R P)$ is not significant for the MW sample; 
thus, there is no significant difference in auditor dismissal between the surprise and nosurprise MW non-accelerated filer companies.

Overall, the regression results strongly suggest that, given a Section $404 \mathrm{MW}$ disclosure, subsequent dismissals of the incumbent auditor are equally likely at companies with and without surprise negative MW disclosures. My conjecture is that this is so because in both groups of companies the audit committee is likely aware of the underlying internal control problems during the fiscal year. While it is reasonable to expect that, audit committees would react negatively to negative surprises, internal control decisions involve significant professional judgment that evolves over time. Hence, auditors can plausibly explain the year-end negative surprise MW disclosure; this in turn results in no additional likelihood of dismissal for the auditors of surprise MW companies, when compared to auditors of the no-surprise MW companies.

If the above argument is valid, then I should similarly expect no differences between surprise and no-surprise MW companies in the turnover of CFOs following an initial Section $404 \mathrm{MW}$ disclosure. If the audit committees - and, presumably, the rest of the board - are aware of the underlying internal control issues before the fiscal year-end, then the fact that the year-end Section 404 MW disclosure is a "surprise" should not by itself result in a higher likelihood of CFO turnover for the surprise MW companies when compared to the group of no-surprise MW companies. I investigate this issue below. 


\section{CFO TURNOVER AFTER SURPRISE MW DISCLOSURES}

\section{METHOD}

I use a logistic regression model to examine the association between subsequent CFO changes and (a) the disclosures of MWs compared to clean Section 404 reports, (b) clean SOX 404 disclosures with and without SOX 302 MW disclosures (i.e., between positive-surprise companies and control companies), and (c) negative-surprise vs. no surprise MW disclosures. My regression model controls for other factors that can be associated with CFO changes; the control variables are based on prior studies (Gietzmann, Marra, \& Pettinicchio, 2016; K. Johnstone et al., 2011; Li et al., 2010; Wang \& Huang, 2013) and control for financial and executive characteristics shown to be associated with CFO changes. The logistic regression model is:

$$
\begin{aligned}
C F O C H G= & \beta_{0}+\beta_{1} * M W(P S U R P / S U R P)+\beta_{2} * R O A+\beta_{3} * L E V+\beta_{4} * S E G S+ \\
& \beta_{5} * R E S T+\beta_{6} * M \& A+\beta_{7} * S I Z E Q+\beta_{8} * Y O U N G+\beta_{9} * D I S+ \\
& \beta_{10} * G R O W T H+\beta_{11} * C E O \_C H A I R+y e a r+\text { industry }+ \text { error }
\end{aligned}
$$

The dependent variable in the above model, $C F O C H G$, equals 1 if there is a CFO turnover within one-year of a MW disclosure and 0 otherwise. I first use the full-sample and examine the difference between companies with clean Section 404 opinions and companies with MW disclosures: the variable of interest here is $M W$, which equals 1 for companies with MW disclosures and 0 otherwise. In the second regression, the sample includes companies with clean Section 404 reports: the variable of interest here is PSURP which equals 1 if there is Section $302 \mathrm{MW}$ disclosure during the preceding quarters of the year and 0 if there is no Section $302 \mathrm{MW}$ disclosure. In the third regression, the sample includes only the MW companies: the variable of interest here is $S U R P$ which equals 1 if 
there is a surprise MW disclosure and 0 if there is a no-surprise MW disclosure. All the other variables are defined in the appendix. I winsorize continuous variables at the 1 st and the 99th percentiles. The data selection is presented in Table 1.

\section{RESULTS}

Accelerated Filers

Table 10 presents the mean differences between (a) companies with MW SOX 404 disclosures and clean 404(b) opinions, (b) clean 404(b) firms with and without prior Section 302 MW disclosures, and (c) negative surprise and no-surprise MW disclosures for accelerated filers. Consistent with prior research, I find that companies with MW disclosures, when compared to companies with clean SOX 404 reports, are (1) have worse financial performance and are in worse financial condition, (2) more likely to dismiss their CFO, (3) less likely to have a CEO who also is the chairman of the board, (4) more likely to have fewer operating segments, (5) more likely to have had accounting restatements in the last three years, (6) more likely to be larger companies as measured by size decile, and (7) more likely to have sales growth. In the clean SOX 404 sample, companies with Section 302 MW disclosures when compared to companies with clean SOX 302 reports, have similar characteristics as Section 404 MW companies as explained in above paragraph. However, there is no significant difference between clean Section 404 with and without Section 302 MW disclosures in sales growth. Finally, considering only the MW companies, the mean values of the control variables generally do not differ based on the "surprise" status, except that no-surprise companies are (a) more likely to be more leveraged, (b) more likely to have had restatements over the last three years, and (c) more likely younger than 
negative surprise companies. Furthermore, negative surprise companies are more likely to have a CEO who is also the chairman of the board.

Panel A of Table 11 provides details about the univariate association between the three samples and subsequent CFO changes for accelerated filer companies. The first $2 \times 2$ table of Panel A of Table 11, shows that 304 of the 1146 companies with MW disclosures (26.5 percent) had a CFO change within one year of the MW disclosure. In contrast, 4,282 of the 27,988 companies (15.3 percent) with clean Section 404 opinions had CFO change within the subsequent year. The difference is statistically significant $(p<.0001)$. The middle $2 \times 2$ table of Panel A of Table 11 shows that 61 of the 325 clean Section 404 accelerated filer companies with Section $302 \mathrm{MW}$ during the preceding quarters of the year (18.8 percent) had CFO turnover within one year of the MW disclosure. In the accelerated filer companies with clean Sections 302 and 404, 4,221 of the 27,663 companies (15.3 percent) had CFO change within one year. The difference is statistically significant $(p<.1)$. The last $2 \times 2$ table of Panel A of Table 11 also shows that 227 of the 893 accelerated filer companies with a surprise MW disclosure (25.4 percent) had CFO change turnover within one year of the MW disclosure. Finally, 77 of the 253 no-surprise MW companies (30.4 percent) had CFO change within one year. The difference is not significant.

Panel B shows that, when considering the full sample of accelerated filers, the overall regression model is significant $(\mathrm{p}<.001)$. The coefficient of MW is positive and significant, indicating that subsequent CFO changes are more likely in companies with MW disclosures when compared to companies with clean Section 404 opinions. However, the second and third regressions in Panel B of Table 11, using only clean Section 404 accelerated filers with and without Section $302 \mathrm{MW}$ disclosures and the MW companies, 
are not significant. The coefficient of PSURP and SURP are also not significant in the model. Section $302 \mathrm{MW}$ disclosures during the preceding quarters of the same year does not lead to greater CFO turnover for clean Section 404 accelerated filers. Likewise, given a Section 404 MW disclosure, there appears to be no significant difference between MW firms with and without a surprise disclosure for the likelihood of CFO turnover in the year following the MW disclosure.

Non-Accelerated Filers

Table 12 presents the mean differences between (a) companies with MW SOX 404 disclosures and clean SOX 404, (b) clean SOX 404 firms with and without prior Section 302 MW disclosures, and (c) surprise and no-surprise MW disclosures for non-accelerated filers. Results for SOX 404 MW disclosures and clean SOX 404 reports are similar to results for the accelerated filers presented in Table 10. In contrast to Table 10, CEO_CHAIR is not significantly different between SOX $404 \mathrm{MW}$ and clean SOX 404 reports. In addition, SOX 404 MW non-accelerated filer companies are more leveraged and have more M\&A than clean SOX 404 companies. Table 12 also shows that, in the clean SOX 404 sample, companies with Section 302 MW disclosures when compared to companies with clean SOX 302 reports, have similar characteristics as Section 404 MW companies. However, there is no significant difference between clean Section 404 with and without Section 302 MW disclosures in sales growth (GROWTH), CFO turnover (CFOCHG), merger and acquisition (M\&A), and CEO Chair duality (CEO_CHAIR). Finally, for MW sample, the mean values of the control variables generally do not differ 
based on the "surprise" status except that no-surprise companies are (a) more likely to be younger, and (b) more likely to have had restatements over the last three years.

The first $2 \times 2$ table, on the left-hand side Panel A of Table 13, shows that 170 of the 744 companies with MW disclosures (22.9 percent) had a CFO change within one year of the MW disclosure. In contrast, 1,099 of the 6,749 non-accelerated companies (16.3 percent) with clean Section 404 opinions had CFO change within the subsequent year. The difference is statistically significant $(\mathrm{p}<.0001)$. The middle $2 \times 2$ table of Panel A of Table 13 shows that 22 of the 139 clean Section 404 accelerated filer companies with Section $302 \mathrm{MW}$ during the preceding quarters of the year (15.8 percent) had CFO change within one year of the MW disclosure. In the non-accelerated filer companies with clean Sections 302 and 404 reports, 1,077 of the 6,610 companies (16.3 percent) had CFO change within one year. The difference is not statistically significant. Finally, the last 2x2 in Panel A of Table 13 also shows that 131 of the 575 accelerated filer companies with a surprise MW disclosure (22.8 percent) had CFO turnover within one year of the MW disclosure. In the no-surprise MW group, 39 of the 169 companies (23.1 percent) had CFO change within one year. Here again, the difference is not significant.

Panel B shows that, when considering the full sample of non-accelerated filers, the overall regression model is significant $(\mathrm{p}<.05)$. The coefficient of $M W$ is positive and significant, indicating that subsequent $\mathrm{CFO}$ changes are more likely in companies with MW disclosures when compared to companies with clean Section 404 opinions. However, the second and third regressions in Panel B of Table 13, using only clean Section 404 nonaccelerated filers with and without Section $302 \mathrm{MW}$ disclosures and the MW companies, are not significant. The coefficient of PSURP and SURP are also not significant in the 
model. This indicates that Section $302 \mathrm{MW}$ disclosures during the preceding quarters of the same year do not lead to CFO turnover for clean Section 404 non-accelerated filers. Likewise, given a Section $404 \mathrm{MW}$ disclosure, there appears to be no significant difference between SOX 404 MW non-accelerated firms with and without a surprise disclosure for the likelihood of CFO turnover in the year following the MW disclosure.

In summary, in terms of consequences, neither auditor dismissal nor CFO turnover differs between negative surprise and no-surprise firms in the year after a Section $404 \mathrm{MW}$ disclosure. These results are consistent with my conjecture that since audit committees are likely aware of the underlying internal control problem during the year, the absence of prior warning can be excused on the grounds that such judgments necessarily involve professional judgments which can evolve over time.

\section{SHAREHOLDER VOTING AFTER SURPRISE MW DISCLOSURES METHOD}

I use a multiple regression model to examine the association between shareholder voting on auditor ratification and (a) the disclosures of MWs compared to clean Section 404 reports, (b) in the subset of companies with clean Section 404 opinions, the disclosures of MWs in Section 302 filings compared to clean Section 302 reports, and (c) surprise vs. no surprise MW disclosures. The control variables are based on prior studies and control for financial and audit characteristics shown to be associated with shareholder voting (Dao 
et al., 2008; Raghunandan, 2003; Sainty, Taylor, \& Williams, 2002; Tanyi \& Roland, 2017). ${ }^{6}$ The OLS regression model is:

$$
\begin{aligned}
\text { VOTE }= & \theta_{0}+\theta_{1} * M W(P S U R P / S U R P)+\theta_{2} * L N T A+\theta_{3} * B I G 4+\theta_{4} * N A S R+ \\
& \theta_{5} * L N T E N+\theta_{6} * G C+\theta_{7} * R E S T+\theta_{8} * L O S S+\theta_{9} * G R O W T H+ \\
& \theta_{10} * R O A+\text { year }+ \text { industry }+ \text { error }
\end{aligned}
$$

The dependent variable in the above regression, VOTE, is the natural log of the proportion of shareholder votes against, or abstaining from, auditor ratification. As before, I first use the full-sample and examine the difference between companies with Section 404 MW and companies with clean opinions: the variable of interest here is $M W$. In the second regression, the sample includes companies with clean Section 404 reports with and without SOX $302 \mathrm{MW}$ disclosures. The variable of interest here is PSURP which equals 1 if there is Section $302 \mathrm{MW}$ disclosure during the preceding quarters of the year and 0 if there is no Section 302 MW disclosure. In the third regression, the sample includes only the MW companies. The variable of interest here is $S U R P$ which equals 1 if SOX $404 \mathrm{MW}$ disclosure is a surprise (i.e., without SOX 302 MW during the preceding quarters of the year), and 0 if SOX $404 \mathrm{MW}$ disclosure is not a surprise. All the other variables are defined in the appendix. I winsorize continuous variables at the 1 st and the 99 th percentiles. The data selection is presented in Table 1.

\footnotetext{
${ }^{6}$ Note that the sample size for the voting analysis is smaller than that in Tables 7 and 9. Prior studies show that shareholder voting, which is voluntary, is much less likely in smaller companies (Hermanson et al. 2009; Dao et al. 2012).
} 
I examine the shareholder ratification votes that occur in the fiscal year after the initial MW disclosure. Since most shareholder votes occur during the second quarter of the fiscal year, most of the votes occur within four months of the 10-K filing that includes the MW disclosure. I delete companies that had an auditor change at any time during the 365 days before the vote date; this is to reduce the effects that may be attributable to auditor change following the MW disclosure in the annual or quarterly filings.

Consistent with prior research (Barua et al., 2017; Dao et al., 2008; Raghunandan, 2003), I use the ratio of number of votes against, or abstaining from, auditor ratification as the numerator and the total number of votes cast as the denominator to calculate shareholder dissatisfaction. Further, again following prior research, given the skewness in the distribution of the vote proportion, I take the natural logarithm of the vote proportion to arrive at my dependent variable for the analysis, VOTE.

\section{RESULTS}

\section{Accelerated Filers}

Table 14 presents the mean differences between companies with MW SOX 404 disclosures and clean 404(b) opinions; clean 404(b) firms with and without prior Section 302 MW disclosures; and surprise and no-surprise MW disclosures for accelerated filers. Consistent with prior research, I find that companies with MW disclosures, when compared to companies with clean SOX 404 reports, are (1) in worse financial condition and have worse financial performance, (2) more likely to smaller, (3) more likely to have shorter auditor tenure, (4) more likely to have going concern modified audit opinion, (5) less likely to be audited by Big 4 auditors, (6) less likely to purchase non-audit services, (7) more 
likely to have sales growth, and (9) more likely to have had restatements in the last three years. There is no difference in the proportion of votes against or abstaining from auditor ratification between Section 404 MW and clean Section 404 companies. In the clean SOX 404 sample, companies with Section 302 MW disclosures when compared to companies with clean SOX 302 reports, have similar characteristics as Section 404 MW companies. Further, there is no significant difference in sales growth, going concern opinions and having Big 4 auditors between clean Section 404 companies with and without Section 302 MW disclosures. Finally, in the MW sample, the mean values of the control variables generally do not differ based on the "surprise" status except that no-surprise companies are (1) more likely to receive going concern opinion, and (2) more likely to have had restatements over the last three years.

Panel A of Table 15 provides results from univariate analysis of differences in shareholder voting on auditor ratification for accelerated filer companies comparing MW disclosing companies with clean 404(b) opinions; clean Section 404(b) companies with and without Section 302 MW disclosures; and negative and no-surprise MW disclosures. Panel B of Table 15 provides the results from the regression model. The regressions are statistically significant for the full sample and for the MW disclosure sample, but not for the clean Section 404 sample. In the first regression, the coefficient of $M W$ indicates that shareholder votes to not ratify the auditor is significantly higher at companies with MW disclosures than at clean Section 404 companies. In the third regression, the coefficient for SURP indicates that shareholders are marginally more likely to vote against auditor ratification after surprise MW disclosures than after no-surprise MW disclosures. 
Thus, it appears that negative surprise MW disclosures have an impact on the voting decisions of shareholders. I attribute this to the fact that the MW disclosure at the year-end is likely a surprise to shareholders.

\section{Non-Accelerated Filers}

Table 16 presents details about the differences between companies (a) with and without MW SOX 404 disclosures, (b) clean SOX 404 firms with and without prior Section $302 \mathrm{MW}$ disclosures, and (c) surprise and no-surprise MW disclosures for non-accelerated filers. Consistent with prior research, I find that companies with MW disclosures, when compared to companies with clean SOX 404 reports, are (1) in worse financial condition, (2) more likely to have auditors with shorter tenure, (3) more likely to have going concern modified opinion, (4) less likely to be audited by Big 4 auditors, and (5) more likely to have had restatements in the last three years. There is no difference in the proportion of votes against or abstain from auditor ratification between SOX 404 MW and clean SOX 404 companies.

In the clean SOX 404 sample, companies with Section 302 MW disclosures when compared to companies with clean SOX 302 reports are (1) more likely to receive going concern opinion, (2) more likely smaller, (3) more likely in worse financial performance and are in worse financial condition, (4) less likely to buy non-audit services, (5) more likely to have had restatements in the last three years, and (6) more likely to have higher adverse auditor ratification votes. The mean values of the control variables generally do not differ based on the "surprise" status for the MW sample except that no-surprise companies are (1) less likely to have sales growth, and (2) more likely to have had 
restatements over the last three years, and (3) more likely to have higher auditor ratification votes.

Panel A of Table 17 provides results from univariate analysis of differences in shareholder voting on auditor ratification for non-accelerated filer companies comparing (a) SOX 404 MW disclosures with clean SOX 404 report; (b) clean SOX 404 companies with and without Section 302 MW disclosures; and, (c) negative and no-surprise MW disclosures for non-accelerated filer companies. Panel B of Table 17 provides the results from the regression model for the non-accelerated filer companies. The regression for the full sample is not significant. The regressions for clean Section 404 firms with and without Section 302 MW disclosures in the preceding quarters of the year indicate that nonaccelerated filer companies with clean Section 302 reports are more likely to vote against the auditor than those with Section 302 MW disclosures. Likewise, the regression for MW sample shows that no-surprise MW disclosure companies are more likely to vote against the auditor than surprise MW disclosure companies.

Thus, it appears that no-surprise MW disclosures have an impact on the voting decisions of shareholders for the non-accelerated filer companies. This suggests that shareholders blame the auditor for Section $302 \mathrm{MWs}$ that remain un-remediated at the end of the year.

\section{SUMMARY}

In this part of the dissertation, I examine the association between surprise material weakness disclosures and auditor dismissal, CFO turnover, and shareholders' vote against auditor ratification. My findings indicate that accelerated filers that disclose Section 404 
MW are more likely to dismiss their auditors and CFOs, and have higher proportion of shareholders not voting to ratify the auditor, than clean Section 404 companies. Clean SOX 404 accelerated filer companies with prior Section $302 \mathrm{MW}$ disclosures also are more likely to dismiss their auditors than clean SOX 404 accelerated filer companies without Section 302 MW disclosures. However, there is no significant difference between the two groups when it comes to $\mathrm{CFO}$ turnover or shareholder auditor ratification vote. There is no significant difference between negative surprise and no-surprise SOX 404 MW accelerated filer companies in auditor dismissal and CFO turnover. This suggests that the likelihood of auditor and CFO dismissal is the same between negative surprise and no surprise SOX 404 MW accelerated filer companies. However, my findings indicate that shareholders of accelerated filer companies with negative surprise SOX 404 MW are more likely to vote against auditor ratification than shareholders of no-surprise SOX $404 \mathrm{MW}$ accelerated filer companies.

When it comes to non-accelerated filer companies, the results show that companies with Section 404 MWs are more likely to dismiss their auditors and CFOs than clean Section 404 companies. However, there is no significant difference between the two groups as to shareholder votes on auditor ratification. Clean SOX 404 non-accelerated filer companies with prior Section $302 \mathrm{MW}$ disclosures also are more likely to dismiss their auditors than non-accelerated filer companies without prior Section 302 MW disclosures. However, there is no significant difference between the two groups when it comes to CFO turnover. Shareholders of clean Section 404 non-accelerated filers without prior $302 \mathrm{MW}$ disclosures are more likely to vote against auditor ratification than clean Section 404 nonaccelerated companies with Section $302 \mathrm{MW}$ disclosures. Further, there is no significant 
difference between negative surprise MW and no-surprise MW non-accelerated companies in auditor dismissal and CFO turnover. However, shareholders of non-accelerated filer companies with no surprise SOX 404 MW disclosures are more likely to vote against auditor ratification than shareholders of negative surprise SOX 404 MW non-accelerated filer companies. 


\section{SURPRISE MATERIAL WEAKNESS DISCLOSURES AND AUDIT FEES}

In this section, I examine the association between material weakness disclosures made pursuant to Sections 302 and 404 of the Sarbanes-Oxley Act (United States Congress, 2002) and audit fees. This study focuses on audit fees for firms with SOX 404 MW disclosure and clean SOX 404 reports (full sample); clean SOX 404 firms with and without SOX 302 MW disclosures during the first three quarters of the same year (clean SOX 404 sample); and firms with year-end SOX 404 MW disclosures with and without SOX 302 MW disclosures during the first three quarters of the same year (MW sample). Building on prior research (Hermanson \& Ye, 2009; Munsif et al., 2013), I refer to firms that disclose MWs at year end in their Section 404 filings but without prior Section 302 MW disclosures as "negative surprise" firms. I refer to firms that disclose MWs at year end in their Section 404 filings with prior Section 302 MW disclosures as "no-surprise" firms. On the other hand, I refer to firms that disclosed Section 302 MW during the first three quarters of the year and issue clean Section 404 reports as "positive surprise" firms.

In 2010, the Public Company Accounting Oversight Board (PCAOB, 2010b) issued Auditing Standard No. 12 on auditor's assessment of risks related to material misstatement. Paragraphs 18-40 discusses risk assessment related to internal control over financial reporting. The language on auditor's risk assessment included the following excerpt taken from Paragraphs 4 and 5:

4. The auditor should perform risk assessment procedures that are sufficient to provide a reasonable basis for identifying and assessing the risks of material misstatement, whether due to error or fraud, and designing further audit procedures. 
5. Risks of material misstatement can arise from a variety of sources, including external factors, such as conditions in the company's industry and environment, and company-specific factors, such as the nature of the company, its activities, and internal control over financial reporting.

Auditors conduct risk assessment to (1) obtain an understanding of internal control, (2) evaluate the design of controls that are relevant to the audit and determine whether the controls have been implemented, (3) obtain an understanding of the company's control environment, (4) obtain an understanding of management's process for identifying risks relevant to financial reporting objectives, (5) obtain an understanding of the information system, (6) obtain an understanding of control activities, (7) perform walkthroughs as part of obtaining an understanding of internal control over financial reporting, and (8) test controls for the purpose of assessing control risk. The presence of a material weakness creates significant additional work for auditors such as testing and changes in the audit program, discussions with client management, documentation to classify a weakness as a material weakness as opposed to a significant deficiency (Raghunandan and Rama, 2006).

\section{BACKGROUND}

Prior Research on Internal Control Disclosures and Audit Fees

Raghunandan \& Rama (2006) examine 660 accelerated filer manufacturing firms with a December 31, 2004 fiscal year end that had filed their 10-Ks by May 15, 2005, and find that audit fees are 43 percent higher for clients with a material weakness disclosure compared to clients without such disclosure. Hoitash, Hoitash, \& Bedard (2008) use a sample of 2,501 accelerated filers from November 2004 through October 2005 and find that: (1) audit fees are positively associated with Section 404 ICFR problems, (2) audit fees 
are adjusted for problem severity in the 404 period documenting a significant association of audit fees with Section $404 \mathrm{MW}$, but an insignificant association of SD, (3) significant associations of fees with certain pervasive problems that could potentially impact multiple accounts, and (4) companies disclosing internal control problems under Section 302 continue to pay higher fees the following year even in the absence of Section $404 \mathrm{MW}$ disclosure. Hoitash, Hoitash, \& Bedard (2008) also find that systemic weaknesses have a greater impact on audit fees than non-systemic weaknesses.

Hogan \& Wilkins (2008) examine audit fees prior to the implementation of SOX Section 404 using 284 Section 302 ICD observations and 6,451 matched industry observations. Their findings indicate that audit fees are higher for clients that disclosed an MW pursuant to Section 302 of SOX after July 2002.

While the above studies examined the effect of internal control weakness disclosures on audit fees, Krishnan, Rama, and Zhang (2008) use a sample of 172 companies with SOX 404 costs to analyze the total cost of compliance. They find that the presence of a material weakness significantly increases the total SOX 404 costs and SOX 404 audit costs.

Munsif et al. (2011) examine audit fees for Section 404 for the first 4 years of SOX implementation. They find that remediating firms pay lower audit fee compared to firms that continue to disclose material weakness in internal control; however, the remediating firms pay, in the year of remediation as well as one and two years after remediation, significantly higher audit fees compared to firms that have clean Section 404 reports in each of the first four years. Using a sample of $1451(12,337)$ adverse (clean) Section 404 firm years from 2004-2007, Hoag and Hollingsworth (2011) find that (1) audit 
fees decline for companies that remediate a material weakness, (2) regardless of the decline audit fee after remediation, audit fees are 19 percent higher three years after the initial remediation as compared to a sample of companies who never report an adverse 404 opinion, and (3) fee premiums are nearly double for companies reporting consecutive adverse 404 opinions.

In summary, prior research related to the association between internal control reporting and audit fees has concentrated mainly on accelerated filers. One exception is the study by Bedard, Hoitash, \& Hoitash (2008) which examines the association of audit fees with internal control disclosures under Section 302 using 35/62/2199 ICD/SD/clean and 152/97/2047 ICD/SD/clean non-accelerated filer companies for 2003 and 2004, respectively. The study finds that (1) companies disclosing Section 302 problems pay higher audit fees, (2) fees are adjusted for risk associated with problem severity, and (3) there is significant fee increase for clean companies in 2004 and that companies remediating internal control problems in 2003 continue to pay higher fees in 2004.

In this section, I first establish a strong association of audit fees with internal control problems in: (1) SOX $404 \mathrm{MW}$ disclosures compared to clean SOX 404 (full sample), and (2) SOX 302 MW disclosures compared to clean SOX 302 (clean SOX 404 sample). Then, I examine the difference between surprise and no-surprise SOX $404 \mathrm{MW}$ disclosures in internal control over financial reporting and audit fees using data from 2004-2016.

\section{HYPOTHESES DEVELOPMENT}

Accelerated and non-accelerated filers are subject to different SOX requirements. The Section 302 requirement to establish and certify the effectiveness of internal control 
infrastructure in quarterly filing with the SEC became effective for all quarterly filings on or after August 29, 2002 for both accelerated and non-accelerated filers. SEC annual filings of management report on internal control over financial report (ICFR) under Section 404(a) and auditor's attestation of management report under Section 404(b) became effective for accelerated filers on or after November 15, 2004. SEC annual filings of management's report and certification under Section 404(a) became effective for non-accelerated filers on or after December 15, 2007. After a number of initial postponements of Section 404(b) requirements for non-accelerated filers, the Dodd-Frank Act (DFA, 2010) made the exemption permanent for non-accelerated filers.

Thus, since the auditor opines on internal control over financial reporting for accelerated filers, the auditor's involvement is direct. However, the auditor's involvement in internal control related matters for non-accelerated filers are indirect. The auditor is required to "read the other information of which the auditor is aware because the credibility of the audited financial statements may be undermined by material inconsistencies between the audited financial statements and other information" per SAS 8, and SAS 118 that superseded SAS 8 (PCAOB, 2010a).

Prior studies show that, the competition in the small client segment of the audit market is much greater post-SOX while the large-client segment of the U.S. audit market lacks competition (GAO, 2003; Kohlbeck, Mayhew, Murphy, \& Wilkins, 2008; United States Treasury, 2008). Increased competition in the small audit market may mute the pressures on higher fees for non-accelerated filers. Since the audit needs of non-accelerated filers are different from those of accelerated filers, the association between material weaknesses in internal control and audit fees for non-accelerated filers is expected to be 
lower than the association between material weaknesses in internal control and audit fees for accelerated filers.

Given that the risk/return trade-off, auditors price audit engagements to compensate for the overall level of risk (Johnstone \& Bedard, 2003). Because the presence of a material weakness indicates an increased likelihood of material misstatement, auditors of companies with MW in internals control undertake additional substantive testing.

Prior studies that examine the association between internal control quality and audit fees focus on accelerated filers or have used data from Section 302 disclosures. In this study, I first establish the differential impact of internal control weakness disclosures on audit fees for both non-accelerated and accelerated filers using Section 404 data. Then, I examine the association of Section $302 \mathrm{MW}$ disclosures and audit fees by comparing clean Section 404 reports with and without Section 302 MW disclosures. Finally, I investigate the differential association of surprise and no-surprise SOX 404 MW disclosures and audit fees for both non-accelerated and accelerated filers.

As prior studies have shown association between the presence of material weakness and higher audit fees, I expect strong association between Section 404 MWs in internal control and audit fees for both accelerated and non-accelerated filers. The auditor is expected to factor in Section $302 \mathrm{MW}$ disclosures when determining audit effort, risk and cost. Thus, I also expect strong relationship between Section $302 \mathrm{MW}$ disclosures and audit fees for clean Section 404 reports. Similarly, since the auditor factors in the presence of Section $302 \mathrm{MW}$ disclosure in audit work and pricing, I expect stronger association between audit fees and no-surprise MW disclosures than the association between audit fees and surprise MW disclosures. 
These lead to my third set of hypotheses:

H3a: There is a positive association between SOX 404 material weakness and audit fees.

H3b: There is a positive association between SOX $302 \mathrm{MW}$ and audit fees.

H3c: The audit fee premium associated with no-surprise SOX $404 \mathrm{MW}$ is higher than the audit fee premium associated with surprise SOX $404 \mathrm{MW}$.

\section{METHOD}

I use the following model to examine the association between audit fees and material weaknesses in internal control:

$$
\begin{aligned}
\text { LAFEE }= & \gamma_{0}+\gamma_{1} * M W(P S U R P / S U R P)+\gamma_{2} * L N T A+\gamma_{3} * R O A+\gamma_{4} * L E V+ \\
& \gamma_{5} * S E G S+\gamma_{6} * G C+\gamma_{7} * I N I T I A L+\gamma_{8}^{*} B I G 4+\gamma_{9} * X I D O P+ \\
& \gamma_{10} * F O R E I G N+\gamma_{11} * S P E C I A L I S T+\gamma_{12} * I N V R E C+\gamma_{13} * C R A T I O+ \\
& \gamma_{14} * \text { RESTATE }+\gamma_{15-26} *(\text { Year })+\gamma_{27-30} *(\text { Industry })+\text { error }
\end{aligned}
$$

The dependent variable in the above regression, $L A F E E$ is the natural log of audit fees. As before, I first use the full-sample and examine the difference between companies with clean Section 404 opinions and companies with MW disclosures: the variable of interest here is $M W$. In the second regression, the sample of companies with clean Section 404 reports: the variable of interest here is PSURP which equals 1 if there is Section 302 MW disclosure during the preceding quarters of the year and 0 if there is no Section 302 MW disclosure. In the third regression, the sample includes only SOX 404 MW companies: the variable of interest here is $S U R P$ which equals 1 if there is no SOX $302 \mathrm{MW}$ disclosure during the preceding quarters of the year (negative surprise) and 0 if there is SOX $302 \mathrm{MW}$ disclosure (no-surprise). All the other variables are defined in the appendix. 
The control variables are derived from prior studies (e.g., Ettredge, Emeigh, \& Li, 2014; Hoag \& Hollingsworth, 2011; Munsif, Raghunandan, \& Rama, 2012; Raghunandan \& Rama, 2006) and the variables are measured as of the relevant fiscal year ends. I use $L N T A$ as control variable to proxy for size; for client complexity, I use INVREC, SEGS, and FOREIGN. Client financial condition is measured with CRATIO, ROA, LEV and GC. Following much of prior audit fee research, I use the BIG4 variable for auditor type. I include INITIAL as prior research suggests that initial year audit clients pay a fee discount (e.g., Francis \& Simon, 1987).

\section{RESULTS}

Accelerated Filer Companies

Table 18 provides descriptive data for accelerated filer companies for the three samples. The data show that compared to clean firms, Section 404 MW firms are significantly smaller in size, less likely to have Big4 and/or specialist auditors, are more likely to have a modified opinion due to going concern, are more likely to have restatement, more likely to have fewer business segments, and more likely to have modified opinion due to factors not related to going concern. The data also show that SOX 404 MW firms are less profitable, as measured by $R O A$; more likely to have auditors in their first year of engagement with the company; and are more likely in the high-tech industries than clean SOX 404 firms.

The second set uses the sample of clean SOX 404 reports, and examines differences between firms with or without SOX 302 MW disclosures. Compared to firms with clean SOX 302 firms, firms with SOX 302 MWs have higher current ratio; more modified 
opinion due to going concern; more likely to be in the high-tech industry; more likely to have auditors that are in their first year of engagement; and have more restatements. The results also show that SOX $302 \mathrm{MW}$ firms have lower inventory-receivable ratio; are smaller in size; have fewer number of segments; and are less profitable than clean SOX 302 firms.

The final set compares negative surprise and no-surprise SOX $404 \mathrm{MW}$ firms. The results show that surprise SOX 404 MW firms are less likely to have modified opinion due to going concern; pay less in audit fees; are less leveraged; have less restatement and less extra-ordinary and discontinued operations compared to no-surprise SOX 404 MW firms.

\section{Regression Results}

Table 19 presents the results for the three sample of accelerated filers. In each regression, the overall model is significant and the adjusted R-square is in line with those reported in prior audit fee studies. The first regression in Table 19 presents the results for the full sample which consists of accelerated filers with and without Section 404 material weakness. The control variables are generally significant and with the expected signs, except for $G C$. The coefficient of $M W$ is 0.348 , indicating that firms with material weakness in their Section 404 internal control reporting have audit fees that are 42 percent higher than firms with clean Section 404 opinions. $^{7}$

\footnotetext{
7 When a firm has a material weakness in internal control in the first year, MW becomes 1 . Thus, the value of the dependent variable in the regression increases by $0.348 * 1=0.348$. In a logit regression the value of the dependent variable MW is log transformed, the effect of the dependent variable increasing by 0.348 is given by $\mathrm{e}^{0.348}=1.42$, or the fee increases by 42 percent compared to the situation when there is no material weakness in internal controls.
} 
The second regression in Table 19 presents the regression results for audit fee analysis for clean Section 404 accelerated filers with and without prior Section 302 MW disclosures. Overall regression is significant, and that the coefficient of PSURP is 0.198 . This indicates that clean accelerated filer companies with Section 302 MW disclosures have audit fees that are higher by 22 percent than firms with clean Section 302 opinions.

The third regression in Table 19 presents the regression results of the audit fee analysis for companies with SOX 404 MW opinions-comparing negative- and nosurprise MW companies. The overall regression is significant and that the coefficient of SURP is -0.205 . This indicates that the surprise MW companies have audit fees that are lower by about 19 percent than no-surprise SOX 404 MW companies. This suggests that SOX 302 MWs prompt the auditor to increase its audit risk, and hence leads to higher audit effort and audit fee. The fee increase triggered by Section 302 MW disclosure might provide partial explanation for why surprise MW disclosures are prevalent.

Non-Accelerated Filer Companies

Descriptive Results

Table 20 provides descriptive data for non-accelerated filer companies for the three samples. The first panel shows that compared to clean firms, Section $404 \mathrm{MW}$ firms are significantly smaller in size, less likely to have Big4 and/or specialist auditors, are more likely to have a modified opinion due to going concern, are more likely to have restatement, more likely to have fewer business segments, and less likely to have modified opinion due to factors not related to going concern. The results also show that firms with SOX 404 MWs are less profitable, as measured by $R O A$; more likely to have auditors in their first of 
engagement with the company; more likely to be more leveraged; more likely to pay less in audit fees; and are less likely to be in the high-tech industries than clean SOX 404 firms. Further, SOX 404 MW firms have lower current ratio and lower inventory-receivable ratio compared to clean SOX 404 firms.

The second panel presents the results for non-accelerated filers with clean SOX 404 reports, partitioned by companies with and without SOX 302 MW disclosures. Compared to firms with clean SOX 302 reports, firms with SOX 302 MWs have more modified opinion due to going concern; are more likely to have auditors that are in their first year of engagement; and have more restatements. The results also show that SOX $302 \mathrm{MW}$ firms are smaller in size; have fewer number of segments; are less profitable; and have marginally lower inventory-receivable ratio than Section 302 firms that did not disclose material weakness. The last panel shows the results for non-accelerated filer firms with negativeand no-surprise SOX 404 MWs. The results show that negative surprise SOX $404 \mathrm{MW}$ firms have higher inventory-receivable ratio, pay less in audit fees and are less likely to have restatement compared to no-surprise SOX $404 \mathrm{MW}$ firms.

\section{Regression Results}

Table 21 presents the results for the three samples of non-accelerated filers. In each regression, the overall model is significant and the adjusted R-square is in line with those reported in prior audit fee studies. The first regression in Table 21 presents the regression results for the full sample of non-accelerated filers with and without Section 404 material weakness. The variable of interest is $M W$ which takes the value of 1 if there was Section $404 \mathrm{MW}$ disclosure and 0 otherwise. The results show that there is no significant 
association between SOX $404 \mathrm{MW}$ and audit fee for non-accelerated filer companies. The control variables are generally significant and with the expected signs, except for $G C$ and SPECIALIST.

The second regression in Table 21 provides the results for audit fee analysis for clean Section 404 accelerated filers with and without Section 302 material weakness. PSURP is the variable of interest and takes the value of 1 if there is Section 302 MW

disclosure, else 0 . The control variables are generally significant except for INITIAL, SPECIALIST, and RESTATE. The coefficient of PSURP is 0.172 indicating that, among clean Section 404 non-accelerated filers, companies with Section 302 MW disclosures have audit fees that are higher by about 19 percent.

The third regression in Table 21 presents the results for audit fee analysis for the SOX 404 MW sample comparing negative- and no-surprise SOX 404 MW companies. The overall regression is significant, and that the coefficient of $S U R P$ is -0.129 . This indicates that non-accelerated filers companies with surprise SOX 404 MW have audit fees that are about 12 percent lower than no-surprise SOX 404 MW non-accelerated filer companies. This reinforces the finding in the accelerated filers case discussed above that Section 302 MWs prompts the auditor to increase audit risk, and thus audit effort and fee are higher.

\section{SUMMARY}

In this part of the dissertation, I examine the association between surprise material weakness disclosures and audit fees. My findings indicate that both accelerated and nonaccelerated filers with material weakness in their Section 404 internal control reporting face higher audit fees. Considering only the subset of companies with clean Section 404 
opinions, companies with Section 302 MW disclosures also pay higher fees. Finally, among companies reporting Section $404 \mathrm{MW}$ opinions, negative-surprise companies pay lower fees than the no-surprise MW companies. The latter result offers a potential explanation for the prevalence of negative-surprise MWs, even a decade after SOX. 


\section{SURPRISE MATERIAL WEAKNESS DISCLOSURES AND AUDIT REPORT LAGS}

This study investigates the impact of surprise material weakness (MW) disclosures on the length of time from a company's fiscal year-end to the audit report date-audit report lag (ARL). Timely disclosure of accounting information is of paramount importance in making investment decisions and in the monitoring of investments. Timeliness is one of the fundamental characteristics that makes financial information useful. Hence, regulators are concerned with timely disclosure of financial information of publicly traded companies for investors and other financial statement users. Consistent with such concerns, prior studies have shown that late disclosure of accounting information can lead to higher degree of information asymmetry, and lead to negative market reaction (Bamber, Bamber, \& Schoderbek, 1993).

The Sarbanes-Oxley Act of 2002 (United States Congress, 2002) was enacted by the United States House of Representatives to restore public confidence in the capital market in the aftermath of high level accounting scandals at the onset of the $21^{\text {st }}$ century. Policy makers believed that effective internal control helps companies to safeguard the company's assets, promotes efficient operations, comply with laws and regulations and provide reliable timely financial statements.

SOX also addresses the need for timely financial reporting. Section 409 of SOX authorized the Securities Exchange Commission (SEC) to require its registrants to disclose financial and other important information on a rapid and current basis. Section 409 amends Section 13 of the Securities Exchange Act of 1934 by adding the following: 
"(1) Real Time Issuer Disclosures.-Each issuer reporting under section 13(a) or 15(d) shall disclose to the public on a rapid and current basis such additional information concerning material changes in the financial condition or operations of the issuer, in plain English, which may include trend and qualitative information and graphic presentations, as the Commission determines, by rule, is necessary or useful for the protection of investors and in the public interest.".

Accordingly, the SEC ruled that large accelerated filers file annual financial statements in 60 days beginning with the annual report filed for the fiscal year ending on or after December 15, 2006. While accelerated filers will have a 75-day deadline, nonaccelerated filers continue to have a 90-day deadline to file their annual reports with the SEC (SEC, 2005).

In this fourth part of my dissertation, I examine the association between MW disclosures and audit report lag. Following prior studies, I use audit reporting lag as a proxy for the overall financial reporting lag. I hypothesize that the audit reporting lag would be greater for firms reporting a material weakness in internal control. Specifically, I focus on how poor quality internal control due to surprise MW disclosures differentially impact the audit reporting lag for public companies by filer status: accelerated and non-accelerated.

\section{BACKGROUND}

Prior research related to Audit Report Lag

Ashton, Willingham, \& Elliott (1987), using a sample of 488 randomly selected clients in six industries, find that firms that received qualified audit opinion and had poorer internal controls faced longer audit report lags as compared to firms that did not have such issues. Using a sample of 465 companies listed on Toronto Stock Exchange from 1977 to 
1982, Ashton, Graul, \& Newton (1989) find that client's total assets and auditor's size are inversely related to audit delay. They also find that financial services companies had shorter audit delays than companies in other industries and that companies with negative net incomes had longer audit delays than companies with positive or zero net incomes.

Bamber et al. (1993) investigate the factors that determine audit report lag using data from 972 firms in seven industries. The results suggest that audit report lag increases with auditor business risk, audit complexity and other risk related factors such as loss and qualified opinions. Further, audit report lag decreases as incentives increase to provide the client with timelier audit report. Finally, audit report lag is longer for clients of structured audit firms than for clients of unstructured audit firms.

Schwartz \& Soo (1996) examine audit report lags and earnings announcement lags for firms that switch auditors. They investigate whether audit report and earnings announcement lags are associated with the timing of auditor changes in relation to firms' fiscal year-ends. The results indicate that both audit report and earnings announcement lags are lower (higher) for firms that change their auditor early (late) in the fiscal year. Tanyi, Raghunandan, \& Barua (2010) examine audit reporting lags following voluntary and involuntary auditor changes. They find that former Anderson clients that did not follow their Anderson partner to the new audit firm have significantly higher audit report lag than clients that voluntarily changing auditor from another BIG5 predecessor. They also find that clients with voluntary auditor changes have only marginally higher audit reporting lags compared to clients without auditor changes.

Knechel \& Payne (2001) use a propriety database containing 226 audit engagements, for fiscal year 1991, from an international audit firm. Their results indicate 
that incremental audit effort, the presence of tax issues and the use of less experienced audit staff are positively correlated with audit report lag. Further, they find that audit report lag decreases due to synergistic relationship between non-audit services and audit services.

Lee, Mande, \& Son (2009) use 18,473 firm year sample to examine whether audit report lags are influenced by auditor tenure and the provision of non-audit services by the external auditor, and find that ARLs decline as auditor tenure lengthens. Dao \& Pham (2014) use 7,291 firm-year observations from 2008 to 2010 to examine the association between audit firm tenure and audit report lag. They find that auditor industry specialization weakens the positive association between ARL and short audit firm tenure.

Chen, Smith, Cao, \& Xia (2014) use 6,381 firm year observations to examine the role IT capability in contributing to internal control and external audit. They find that IT capability directly mitigates audit fee increases, but not audit report delay increases. Pham, Dao, \& Brown (2014) using a sample of 8,520 US firms from 2010 to 2012 examine the association between audit report lag and the level of investment opportunity of U.S. firms and find that firms with high investment opportunities are more likely to have longer audit report lags.

Some studies have examined audit report lags in non-U.S. settings. Using a sample of 171 companies from the Athens Stock Exchange, Leventis, Weetman, \& Caramanis, (2005) find that international audit firms are strongly associated with timely audit reporting. Bonsón-Ponte, Escobar-Rodríguez, Borrero-Domínguez, \& Escobar (2008) use 105 companies quoted on the Spanish continuous market at the end of 2002 to 2005 and find that regulatory pressures and company size influence audit report lag. Using a sample of 502 firm-year observations from 2004 to 2008 based on New Zealand stock exchange 
listed companies, Habib \& Bhuiyan (2011) find that the audit report lag is shorter for firms audited by industry specialist auditors.

Prior Research Related to Audit Report Lag and SOX

Ettredge, Li, \& Sun (2006) use 2,344 companies, 331 of which are with SOX 404 MW disclosures in 2003 and 2004, to analyze the impact of internal control quality on audit report lag. They find that the presence of material weakness in internal control is associated with longer delays. Furthermore, they find that compared to specific material weaknesses, general (systemic) material weaknesses are associated with longer delays. Krishnan \& Yang (2009) use a longitudinal sample of 1,077 companies from 2001-2006 and examine audit report lag and earnings announcement lag. They find that audit report lag increased significantly from 2001 to 2006, but the increase was higher during the 2004-2006 period when SOX Section 404 was in effect.

Munsif et al. (2012) use 2839 firm years from 2008 and 2009 and comparing accelerated and non-accelerated filers examine the association between internal control weaknesses and audit report lag. They find that in 2008 , the increase in audit report lag in the presence of material weaknesses in internal control is lower for non-accelerated filers as compared to accelerated filers. Further, they find that the effect of a material internal control weakness on audit report lag is significantly lower in 2009 than in 2008 for accelerated filers, but not for non-accelerated filers. They also find that firms that remediated previosuly dislosed MW have a significant decline in audit report lag; yet, such firms have higher reporting lag than clean Section 404 reporting companies. 
Impink, Lubberink, van Praag, \& Veenman (2012) use a sample of 36,876 company-years to examine the effect of Sarbanes-Oxley on 10-K filing delays. They find that tightened filing deadlines for accelerated and large accelerated filers are not associated with changes in the incidence of late filing. They also find that while Section 404 compliance does not affect filing timeliness for firms with effective internal controls, about half the firms disclosing internal control weaknesses are late filer. Lastly, the authors find that market reactions to late filing notifications are more negative when management provides no meaningful explanation for the delay.

Thus, prior studies have examined a variety of issues related to the effects of SOX on audit report lag. Yet, no prior study has examined the association between surprise MW disclosures and audit report lag. In the fourth part of my dissertation, I investigate the association between material weaknesses in internal control and audit report lag. First, I establish the association between SOX $404 \mathrm{MW}$ and audit report lag. I then examine how such association differs for clean SOX 404 reports with SOX 302 MWs ("positive surprise") and without SOX $302 \mathrm{MW}$ disclosures, and SOX $404 \mathrm{MW}$ companies with and without prior SOX 302 MW reports-negative- and no-surprise SOX 404 MWs.

\section{HYPOTHESES DEVELOPMENT}

In this study, first I establish the differential impact of internal control weakness disclosures on audit report lag for both accelerated and non-accelerated filers using SOX 404 data. Then, using clean SOX 404 reports with and without SOX 302 MW disclosures, I investigate the association of Section 302 MW disclosures and audit report lag. Finally, using a sample of companies with SOX $404 \mathrm{MW}$ disclosures, I examine the differential 
impact of negative- and no-surprise MW disclosures on audit report delay for both nonaccelerated and accelerated filers.

As prior studies have shown association between the presence of material weakness and higher audit report lag, I expect a significant association between Section 404 MWs in internal control and audit report lag for both accelerated and non-accelerated filers.

Section 302 MW disclosures also signal the need for heightened effort by the auditor to conduct more substantive testing. Thus, in the sample of clean SOX 404 companies, I expect a significant association between SOX 302 MW disclosures and audit report lag than the association between clean SOX 302 reports and audit report lag.

Finally, more audit effort might be needed for both SOX 404 MW companies with and without Section $302 \mathrm{MWs}$. The discovery of MW for surprise group might necessitates that the auditor undertakes more tests as is the case for determining the extent of problems for the no-surprise companies. Thus, I expect the association between surprise and nosurprise MW companies and audit report lag to be the same.

These lead to the following hypotheses:

H4a: There is a positive association between SOX 404 material weakness disclosures and audit report lag.

H4b: For the subset of firms with a clean Section 404 opinion, there is a positive association between SOX $302 \mathrm{MW}$ disclosures and audit report lag.

H4c: $\quad$ The audit report lag associated with surprise SOX $404 \mathrm{MW}$ is not different from the audit report lag associated with no-surprise SOX $404 \mathrm{MW}$. 


\section{METHOD}

I use the following regression model to test my hypotheses:

$$
\begin{aligned}
L N A R L= & \delta_{0}+\delta_{1} * M W(P S U R P / S U R P)+\delta_{2}^{*} A U C H G+\delta_{3} * A U F E E+ \\
& \delta_{4} * G C+\delta_{5} * H I T E C H+\delta_{6} * I N I T I A L+\delta_{7} * L N T A+\delta_{8} * L E V+ \\
& \delta_{9} * L O S S+\delta_{10} * S E G S+\delta_{11} * O P I N+\delta_{12} * R E S T A T E+\delta_{13} * R O A+ \\
& \delta_{14} * X I D O P+\delta_{15} * S P E C I A L I S T+\delta_{16} * B I G 4+\delta_{17-}{ }^{*}(\text { Year })+ \\
& \delta_{29-32} *(\text { Industry })+\text { error }
\end{aligned}
$$

The dependent variable in the above regression, $L N A R L$ is the natural log of the number of days between the fiscal year-end and date of the audit report. As before, I first use the full sample and examine the difference between companies with clean SOX 404 opinions and companies with SOX 404 MW disclosures: the variable of interest here is $M W$. In the second regression, the sample includes only companies with clean SOX 404 reports: the variable of interest here is $P S U R P$ which equals 1 if there is Section $302 \mathrm{MW}$ disclosure during the preceding quarters of the year and 0 if there is no SOX $302 \mathrm{MW}$ disclosure. In the third regression, the sample includes only SOX $404 \mathrm{MW}$ companies: the variable of interest here is $S U R P$ which equals 1 if there is no SOX $302 \mathrm{MW}$ disclosure during the preceding quarters of the year (negative surprise) and 0 if there is SOX $302 \mathrm{MW}$ disclosure (no-surprise). All the other variables are defined in the appendix.

All control variables are derived from prior studies (Ettredge et al., 2006; Jayanthi Krishnan \& Yang, 2009; Tanyi et al., 2010). For the fourth part of my dissertation, I use the same sample as in the first two parts of the dissertation. I winsorize continuous variables at the 1st and the 99th percentiles. The data selection is presented in Table 1. 


\section{RESULTS}

Accelerated Filers

Table 22 provides descriptive data about the variables in the audit reporting lag model for the three sample of accelerated filers. The first panel of Table 26 shows, in the full sample, that SOX 404 MW companies are significantly different from clean SOX 404 companies in all control variables except leverage (LEV). SOX $404 \mathrm{MW}$ accelerated filers are more likely to have: higher auditor change $(A U C H G)$, higher audit report lag (LNARL), higher audit fee (AUFEE), higher going concern audit opinion $(G C)$, be in the high-tech industry (HITECH), higher initial year auditors (INITIAL), higher negative income (LOSS), more modified audit report not related to going concern (OPIN), higher rate of restatement during the year (RESTATE), and have extraordinary items and discontinued operations (XIDOP) than clean SOX 404 companies. Conversely, SOX 404 MW companies are more likely to be smaller (LNTA), have fewer business segments (SEGS), are less profitable $(R O A)$, and less likely to be audited by BIG4 auditors than clean SOX 404 companies.

The second panel of Table 22 indicates that in the clean SOX 404 sample, companies with SOX 302 MWs are significantly different from clean SOX 302 companies in most of the control variables, except for auditor type (BIG4), leverage (LEV), modified opinions other than going concern related(OPIN), extraordinary items and discontinued operations $(X I D O P)$ and industry specialist auditors (SPECIALIST). SOX $302 \mathrm{MWs}$ are more likely to have: higher auditor change $(A U C H G)$, higher audit report lag (LNARL), higher audit fee (AUFEE), higher going concern audit opinion $(G C)$, be in the high-tech industry (HITECH), higher initial year auditors (INITIAL), higher negative income (LOSS), and higher rate of restatement during the year (RESTATE) than clean Section 302 
companies. Conversely, clean SOX 404 companies with SOX 302 MWs are more likely to be smaller ( $L N T A)$, have fewer business segments (SEGS), and are less profitable (ROA) than clean SOX 404 companies without SOX 302 MW disclosures.

The last panel of Table 22 shows, in the SOX $404 \mathrm{MW}$ sample, that there is no significant difference between surprise and no-surprise SOX 404 MW accelerated filers except that surprise MW companies are more likely to pay lower audit fees (AUFEE), are less likely to have going concern modified opinions (GC), are more likely to be less leveraged (LEV), less likely to have restatements (RESTATE) and less likely to have extraordinary items and discontinued operations (XIDOP) than no-surprise SOX $404 \mathrm{MW}$ companies.

Regression Results

Table 23 present the results for the three samples of non-accelerated filers. In each regression, the overall model is significant and the adjusted R-square is in line with those reported in prior audit fee studies. The first regression in Table 23 presents the results for the full sample which consists of accelerated filers with and without Section $404 \mathrm{MW}$ disclosures. The coefficient of $M W$ is 0.272 , indicating that firms with material weakness in their Section 404 internal control reporting have increased audit report lag of 31 percent.

The second regression in Table 23 presents the results for audit report lag analysis for clean Section 404 accelerated filers with and without Section 302 material weakness. All of the control variables are significant except for profitability $(R O A)$. The coefficient of PSURP is 0.041 indicating that clean accelerated filer companies with Section 302 material weakness face an increased audit report lag of 4 percent. 
The third regression in Table 23 presents the results for audit report lag analysis for negative-surprise and no-surprise SOX $404 \mathrm{MW}$ companies. SURP is the variable of interest and is equal to 1 if there is a negative surprise MW disclosure, and 0 if there is nosurprise MW disclosure. The coefficient of $S U R P$ is not significant in the regression. The control variables are significantly different except for HITECH, LEV, LOSS, SEGS, and XIDOP.

Non-Accelerated Filers

Table 24 presents the mean differences and p-values for the variables in the audit reporting lag model for the three samples-full, clean SOX 404, and MW-for nonaccelerated filers. The first panel of Table 30 shows that Section 404 MW companies are significantly different from clean Section 404 companies in all control variables except that there is no difference in extraordinary items and discontinued operations (XIDOP).

The second panel of Table 24 shows that the control variables for clean SOX 404 non-accelerated filers with and without Section $302 \mathrm{MW}$ disclosures behave in the same manner as in the clean SOX 404 accelerated filers with and without Section 302 MW disclosures. Notable difference between the two is, whereas HITECH is significant and LEV is insignificant in the case of clean SOX 404 sample of accelerated filers, HITECH is insignificant and LEV is significant in the case of clean SOX 404 non-accelerated filers. The third panel of Tables 24 shows that the control variables are not significantly different between non-accelerated companies with surprise and no-surprise SOX 404 MW disclosures. The only exception is that no-surprise non-accelerated filer companies have 
more restatement (RESTATE) during the year than negative surprise non-accelerated filers.

Regression Results

Table 25 presents the regression results for the three samples of non-accelerated filers. In each regression, the overall model is significant and the adjusted R-square is in line with those reported in prior audit fee studies. The first regression in Table 25 presents the regression results for the full sample of non-accelerated filers with and without Section 404 material weakness. The variable of interest is $M W$ which takes the value of 1 if there was Section 404 MW disclosure and 0 otherwise. The control variables are significant except for ROA and SPECIALIST. The coefficient for $M W$ is 0.185 indicating that MW firms face increased audit report lag of 20 percent.

The second regression in Table 25 provides the results for audit fee analysis for clean SOX 404 non-accelerated filers with and without Section 302 material weakness. PSURP is the variable of interest and takes the value of 1 if there is Section $302 \mathrm{MW}$ disclosure, else 0 . The control variables are significant except for $R O A$. The coefficient of PSURP is 0.057 , indicating that clean Section 404 non-accelerated filer companies with Section 302 MW disclosures have higher audit report lag of 6 percent.

The third regression in Table 25 presents the results for audit fee analysis for nonaccelerated filer companies with Section 404 MW opinions; the comparison is between negative-surprise and no-surprise MW companies. As in the case of accelerated filers, the coefficient of $S U R P$ is not significant in the regression. 


\section{SUMMARY}

In this part of the dissertation, I examine the association between the presence of material weaknesses in internal controls and audit report lag. My findings indicate that for both accelerated and non-accelerated filers the following results hold: (a) companies with material weakness in their Section 404 internal control reporting have higher audit report lag; (b) clean Section 404 filers with Section 302 MW disclosures also have higher audit report lag compared to companies with clean Section 302 filings; and, (c) considering only those companies with an adverse Section 404 report, there is no significant difference in audit report lag between companies with no SOX $302 \mathrm{MW}$ (negative surprise) and companies with SOX 302 MW (no-surprise). 


\section{CONCLUSION}

The Sarbanes-Oxley Act of 2002 (United States Congress, 2002) (SOX) was enacted by the United States House of Representatives to restore public confidence in the capital market in the aftermath of high level accounting scandals at the onset of the $21^{\text {st }}$ century. SOX Section 302 requires that the principal executive officer and the principal financial officer of all public firms to certify their firm's quarterly internal control disclosures. Section 404(a) mandates that management document and test internal control structure and issue report including an assessment of the effectiveness of internal controls related to financial reporting. Section 404(b) requires that a registered public accounting firm attest the assessment made by management.

Two prior studies, examining initial years of Section 404 reporting by accelerated filers (Hermanson \& Ye, 2009) and non-accelerated filers (Munsif et al., 2013), find that that many companies that disclosed material weaknesses in internal controls (MWs) in their annual Section 404 reports did not provide early warning of such problems in their Section 302 certifications for earlier quarters of the same fiscal year. In this dissertation, I extend such research by examining a variety of questions related to surprise MW disclosures using data from 2004-2016.

In the first part of my dissertation, I find that "negative surprise" MW disclosures continue to be pervasive for both accelerated and non-accelerated filers even a decade after SOX. Interestingly, the proportions of Section 404 MW disclosures that were negative surprises are higher in my study, for both accelerated and non-accelerated filers, compared to the two prior studies noted above. I also find that there are a small number of clean 
Section 404 reports with $302 \mathrm{MW}$ disclosures during the prior quarters of the year. Interestingly, even though both fractions are quite small, I find that the proportion of "positive" surprise MW disclosures for non-accelerated filers is higher than that of accelerated filers. I also find that the internal control problems in negative and no-surprise MW disclosures are similar except that no-surprise MW disclosures exhibit more personnel and systematic issues for both the accelerated and non-accelerated filer groups. Further, Section 302 disclosure control factors in positive and no-surprise MW disclosures are similar except that no-surprise MW disclosures exhibit more personnel and systematic issues for both the accelerated and non-accelerated filer groups.

In the second part of my dissertation, I find that surprise MW disclosures have consequences to auditors and managers - although the pattern of results is not uniform. My findings indicate that accelerated filers disclosing Section $404 \mathrm{MW}$ are more likely to dismiss their auditors and CFOs, and have higher adverse shareholder auditor ratification votes than clean Section 404 companies. Turning to the sub-sample of accelerated filers with clean Section 404 opinions, companies with prior Section 302 MW disclosures (i.e., positive surprise disclosers) also are more likely to dismiss their auditors than clean Section 404 companies without Section 302 MW disclosures. However, there is no significant difference between negative surprise and no-surprise groups in auditor dismissal or CFO turnover. My findings, however, indicate that shareholders of accelerated filer companies with negative surprise MW disclosures are more likely to vote against auditor ratification than shareholders of no-surprise MW disclosing accelerated filer companies.

Turning to non-accelerated filers, when using the full sample of companies, I find that the pattern of results is generally similar to those for accelerated filers except that there 
is no significant difference between the two group for shareholder auditor ratification votes. Similarly, in the second set of analyses (comparing positive surprise Section 404 opinions versus no-surprise clean Section 404 opinions), the results for non-accelerated mirrors those for accelerated files except that there is significant difference between the two group when it comes to shareholder ratification vote. Finally, when considering only the subsample of non-accelerated Section $404 \mathrm{MW}$ firms, as with accelerated filers there is no significant difference between negative surprise and no-surprise non-accelerated companies in auditor dismissal or CFO turnover. As to shareholder voting on auditor ratification, unlike in the case of accelerated filer companies, vote against auditor ratification is more likely at no-surprise non-accelerated filer companies than at negative surprise non-accelerated filers.

In the third part of my dissertation, I find that surprise MW disclosures also affect the audit fees paid by companies. My findings indicate that companies with Section 404 MW disclosures have higher audit fees compared to companies with clean Section 404 opinions. Further, considering only the subset of companies with a clean Section 404 opinion, companies that had earlier reported MWs in Section 302 filings (that is, positive surprise companies) also have higher audit fees. Finally, in the subset of companies with an adverse Section 404 opinion, the negative surprise companies have lower audit fees; this provides one explanation for the continuing prevalence of negative surprise MW disclosures.

In the final part of my dissertation, I find that Section 404 MW disclosures are associated with increased audit report lag. Further, considering only the subset of companies with a clean Section 404 filing, companies with Section 302 MW filings also 
have higher audit report lag. However, in the subset of companies with an adverse Section 404 opinion, there is no significant difference in the audit report lag of negative surprise and no-surprise companies.

Section 404 of SOX has been, and continues to be, controversial. There have been numerous efforts by some legislators to exempt an increasing number of companies from complying with the requirements of Section 404 of SOX. For example, the Dodd-Frank Act (DFA 2010) exempted non-accelerated filers from the auditor attestation requirements of Section 404(b); later, the Jumpstart Our Business Startups Act (JOBS, 2012) provided exemption from Section 404(b) requirements of SOX for "emerging growth companies." The latest version of the CHOICE Act, introduced in September 2016 by the Chairman of the House Committee on Financial Services and revised in February 2017, seeks to provide permanent exemption from Section 404(b) of SOX to issuers with market capitalization up to $\$ 500$ million (McKenna, 2017; U.S. House of Representatives, 2017). Thus, Section 404 of SOX is far from settled; hence, relevant empirical evidence, particularly related to companies disclosing material weaknesses (MWs) in internal control over financial reporting, is both necessary and relevant. The empirical evidence provided in this dissertation can be useful for policy debates surrounding Section 404 of SOX. 


\section{APPENDIX}

\section{DEFINITIONS OF VARIABLES}

AUDIS

$M W$

PSURP

$S U R P$

LNTA

LEV

$R O A$

$B M$

GROWTH

LOSS

$G C$

BIG4

NEWCEO

NEWCFO

LNTEN

REST

CFOCHG

SEGS

$M \& A$

SIZEQ

YOUNG
$=1$ if auditor is dismissed within one year of the audit report date, else 0 ;

$=1$ if there is MW in Section 404 disclosure, 0 otherwise;

$=1$ if clean Section 404 and Section $302 \mathrm{MW}$ disclosure, 0 if clean Sections 302 \& 404;

$=1$ if there is a "surprise" MW disclosure, 0 if there Sections 302 and 404 MW disclosure;

$=$ Natural log of client's total assets at the end of the fiscal year;

$=$ Ratio of total liabilities (LT) to total assets (AT);

$=$ Earnings before extraordinary items scaled by total assets;

$=$ Total common equity (CEQ) over market value (MKVALT);

$=$ Change in sales over lagged sales;

$=1$ if negative net income, 0 otherwise;

$=1$ if company received going concern opinion, else 0 ;

$=1$ if audited by one of the Big 4 auditors, else 0 ;

$=1$ if it is the first year of the CEO's tenure, else 0 ;

$=1$ if it is the first year of the CFO's tenure, else 0 ;

$=$ Natural $\log$ of audit tenure at the beginning of the year;

$=1$ if a firm restated financial statements during the prior 3 years, else 0 ;

$=1$ if the $\mathrm{CFO}$ is changed within one year of the audit report date, else 0 ;

$=$ Number of business segments;

$=1$ if there is a merger/acquisition transaction during the year, else 0 ;

$=$ Size of the company, expressed in total assets deciles;

$=1$ if the firm age is less than 6 years, else 0 ; 


\begin{tabular}{|c|c|c|}
\hline$D I S$ & $=$ & $\begin{array}{l}1 \text { if the firm showed a negative net income in the previous } 2 \\
\text { years, else } 0 \text {; }\end{array}$ \\
\hline CEO_CHAIR & $=$ & 1 if the CEO also serves as chairman of the board, else 0 ; \\
\hline VOTE & $=$ & $\begin{array}{l}\text { Natural log of the ratio (Against }+ \text { Abstain)/Total auditor } \\
\text { ratification votes; }\end{array}$ \\
\hline NASR & $=$ & Ratio of total non-audit fees to audit fees; \\
\hline INITIAL & $=$ & 1 if the audit engagement is in their first year, else 0 ; \\
\hline$X I D O P$ & $=$ & $\begin{array}{l}1 \text { if the firm has extraordinary items on its financial } \\
\text { statement, } 0 \text { otherwise; }\end{array}$ \\
\hline FOREIGN & $=$ & 1 if a firm had foreign exchange income (loss), else 0 \\
\hline SPECIALIST & $=$ & 1 if the firm is being audited by an industry specialist, else 0 ; \\
\hline LAFEE & $=$ & Natural log of audit fees; \\
\hline INVREC & $=$ & (Inventory + receivables total) over total assets; \\
\hline CRATIO & $=$ & Current ratio (current assets over total assets); \\
\hline RESTATE & $=$ & $\begin{array}{l}1 \text { if a firm restated financial statements during the current } \\
\text { year, else } 0 \text {; }\end{array}$ \\
\hline$L N A R L$ & $=$ & $\begin{array}{l}\text { Natural log of audit report lag (number of days between } \\
\text { fiscal year-end and date of the audit report); }\end{array}$ \\
\hline$A U C H G$ & $=$ & $\begin{array}{l}1 \text { if there is a new auditor engagement during the year, else } \\
0 ;\end{array}$ \\
\hline AUFEE & $=$ & total audit fees divided by total assets; \\
\hline HITECH & $=$ & $\begin{array}{l}1 \text { if the firm belongs to high-tech industries (three-digit SIC } \\
\text { codes } 283,284,357,366,367,371,382,384 \text {, and } 737 \text { ), } 0 \\
\text { otherwise; }\end{array}$ \\
\hline OPIN & $=$ & $\begin{array}{l}1 \text { if firm receives modified auditor's opinion other than going } \\
\text { concern, else } 0 \text {; }\end{array}$ \\
\hline Year (2004-15) & $=$ & Year dummies 1 for each year 2004- 2015, else 0; \\
\hline Industry (DSIC1-4) & $=$ & $\begin{array}{l}1 \text { if the company has a two-digit SIC code between } 1 \text { and } 19 \text {, } \\
\text { else } 0 \text { (for DSIC } 1 \text { ). DSIC2-DSIC } 4 \text { are based on SICs } 20-39 \text {, } \\
40-49 \text {, and } 50-59 \text {, respectively }\end{array}$ \\
\hline
\end{tabular}


Table 1

Sample Selection

\begin{tabular}{|c|c|c|c|c|c|c|c|c|c|c|c|c|c|c|}
\hline & & & & & & & & & & & & & & \\
\hline Panel A: ALL Reporting Firms & 2004 & 2005 & 2006 & 2007 & 2008 & 2009 & 2010 & 2011 & 2012 & 2013 & 2014 & 2015 & 2016 & Total \\
\hline $\begin{array}{l}\text { SOX } 404 \text { Reports on Internal } \\
\text { Control }\end{array}$ & 9,911 & 9,845 & 9,731 & 9,709 & 9,372 & 8,964 & 8,530 & 8,084 & 7,733 & 7,538 & 7,366 & 6,985 & 6,271 & 110,039 \\
\hline Less: Foreign Companies & 571 & 635 & 703 & 795 & 822 & 820 & 782 & 689 & 602 & 555 & 535 & 518 & 481 & 8,508 \\
\hline Less: Financial Sector/SIC 60-67 & 2,327 & 2,317 & 2,269 & 2,245 & 2,153 & 2,046 & 1,980 & 1,934 & 1,814 & 1,735 & 1,699 & 1,624 & 1,483 & 25,626 \\
\hline $\begin{array}{l}\text { Less: Missing Financial Data \& } \\
\text { Total Assets Less Than \$1 MM }\end{array}$ & 3,871 & 3,456 & 3,319 & 3,256 & 3,057 & 2,897 & 2,644 & 2,303 & 2,191 & 2,090 & 1,837 & 1,638 & 1,335 & 33,894 \\
\hline $\begin{array}{l}\text { Less: 3rd Quarter Restatements \& } \\
\text { Significant Deficiency } \\
\text { Disclosures in 10-Qs }\end{array}$ & 29 & 33 & 19 & 11 & 5 & 4 & 2 & 10 & 4 & 3 & 11 & 6 & 1 & 138 \\
\hline $\begin{array}{l}\text { Less: Prior Two Years } 404 \text { MW } \\
\text { Reports }\end{array}$ & 43 & 254 & 342 & 309 & 288 & 191 & 162 & 140 & 135 & 160 & 198 & 251 & 237 & 2,710 \\
\hline $\begin{array}{l}\text { Less: Non-Accelerated Firms } \\
\text { before } 2007\end{array}$ & 808 & 877 & 851 & -- & -- & -- & -- & -- & -- & -- & -- & -- & -- & 2,536 \\
\hline $\begin{array}{l}\text { Total Firms Years for Further } \\
\text { Analysis }\end{array}$ & 2,262 & 2,273 & 2,228 & 3,093 & 3,047 & 3,006 & 2,960 & 3,008 & 2,987 & 2,995 & 3,086 & 2,948 & 2,734 & 36,627 \\
\hline Accelerated filers & 2,262 & 2,273 & 2,228 & 2,202 & 2,220 & 2,238 & 2,235 & 2,234 & 2,222 & 2,256 & 2,336 & 2,286 & 2,142 & 29,134 \\
\hline Non-Accelerated Filers & -- & -- & -- & 891 & 827 & 768 & 725 & 774 & 765 & 739 & 750 & 662 & 592 & 7,493 \\
\hline \multicolumn{15}{|l|}{ Panel B: Accelerated Filers } \\
\hline Accelerated Filers & 2,262 & 2,273 & 2,228 & 2,202 & 2,220 & 2,238 & 2,235 & 2,234 & 2,222 & 2,256 & 2,336 & 2,286 & 2,142 & 29,134 \\
\hline Clean 404(b) Opinion & 2,064 & 2,081 & 2,130 & 2,120 & 2,187 & 2,205 & 2,205 & 2,184 & 2,154 & 2,165 & 2,242 & 2,200 & 2,051 & 27,988 \\
\hline With Material Weakness & 199 & 192 & 98 & 82 & 32 & 33 & 30 & 50 & 68 & 91 & 94 & 86 & 91 & 1,146 \\
\hline $\begin{array}{l}\text { Prior-Warning In 10-Qs ("No- } \\
\text { Surprise MW") }\end{array}$ & 23 & 43 & 22 & 21 & 13 & 7 & 11 & 4 & 17 & 19 & 24 & 29 & 20 & 253 \\
\hline \multirow{2}{*}{$\begin{array}{l}\text { No Prior-Warning In 10-Qs } \\
\text { ("Surprise MW") }\end{array}$} & 176 & 149 & 76 & 61 & 19 & 26 & 19 & 46 & 51 & 72 & 70 & 57 & 71 & 893 \\
\hline & $88 \%$ & $78 \%$ & $78 \%$ & $74 \%$ & $59 \%$ & $79 \%$ & $63 \%$ & $92 \%$ & $75 \%$ & $79 \%$ & $74 \%$ & $66 \%$ & $78 \%$ & $78 \%$ \\
\hline
\end{tabular}


Table 1

Sample Selection ... Continued

\begin{tabular}{|c|c|c|c|c|c|c|c|c|c|c|c|c|c|c|}
\hline Panel C: Non-Accelerated Filers & 2004 & 2005 & 2006 & 2007 & 2008 & 2009 & 2010 & 2011 & 2012 & 2013 & 2014 & 2015 & 2016 & Tota \\
\hline Non-Accelerated Filers & & & & 891 & 827 & 768 & 725 & 774 & 765 & 739 & 750 & 662 & 592 & 7,493 \\
\hline Clean 404(a) Reports & & & & 815 & 766 & 731 & 698 & 682 & 647 & 632 & 627 & 599 & 552 & 6,749 \\
\hline With Material Weakness & & & & 76 & 61 & 37 & 27 & 92 & 118 & 107 & 123 & 63 & 40 & 744 \\
\hline $\begin{array}{l}\text { Prior-Warning In 10-Qs ("No- } \\
\text { Surprise MW") }\end{array}$ & & & & 15 & 9 & 9 & 8 & 19 & 27 & 27 & 29 & 13 & 13 & 169 \\
\hline \multirow{2}{*}{$\begin{array}{l}\text { No Prior-Warning In 10-Qs } \\
\text { ("Surprise MW") }\end{array}$} & & & & 61 & 52 & 28 & 19 & 73 & 91 & 80 & 94 & 50 & 27 & 575 \\
\hline & & & & $80 \%$ & $85 \%$ & $76 \%$ & $70 \%$ & $79 \%$ & $77 \%$ & $75 \%$ & $76 \%$ & $79 \%$ & $68 \%$ & $77 \%$ \\
\hline \multicolumn{15}{|l|}{ Panel D: Positive Surprise } \\
\hline $\begin{array}{l}\text { Clean 404(b) Opinion (Accelerated } \\
\text { Filers) }\end{array}$ & 2,063 & 2,081 & 2,130 & 2,120 & 2,188 & 2,205 & 2,205 & 2,184 & 2,154 & 2,165 & 2,242 & 2,200 & 2,051 & 27,988 \\
\hline $\begin{array}{l}\text { Clean Section } 302- \\
\text { No } 404 \text { MW Disclosure }\end{array}$ & 2,055 & 2,033 & 2,083 & 2,088 & 2,162 & 2,183 & 2,196 & 2,166 & 2,139 & 2,150 & 2,205 & 2,172 & 2,031 & 27,663 \\
\hline \multirow{2}{*}{$\begin{array}{l}\text { Prior-Warning In 10-Qs - } \\
\text { No } 404 \text { MW Disclosure } \\
\text { ("Positive-Surprise") }\end{array}$} & 8 & 48 & 47 & 32 & 26 & 22 & 9 & 18 & 15 & 15 & 37 & 28 & 20 & 325 \\
\hline & $0.4 \%$ & $2.3 \%$ & $2.2 \%$ & $1.5 \%$ & $1.2 \%$ & $1.0 \%$ & $0.4 \%$ & $0.8 \%$ & $0.7 \%$ & $0.7 \%$ & $1.7 \%$ & $1.3 \%$ & $1.0 \%$ & $1.2 \%$ \\
\hline $\begin{array}{l}\text { Clean 404(a) Reports } \\
\text { (Non-Accelerated Filers) }\end{array}$ & & & & 815 & 766 & 731 & 698 & 682 & 647 & 632 & 627 & 599 & 552 & 6,749 \\
\hline $\begin{array}{l}\text { Clean Section } 302- \\
\text { No } 404 \text { MW Disclosure }\end{array}$ & & & & 796 & 757 & 720 & 689 & 671 & 630 & 614 & 603 & 589 & 541 & 6,610 \\
\hline \multirow{2}{*}{$\begin{array}{l}\text { Prior-Warning In 10-Qs - } \\
\text { No } 404 \text { MW Disclosure } \\
\text { ("Positive-Surprise") }\end{array}$} & & & & 19 & 9 & 11 & 9 & 11 & 17 & 18 & 24 & 10 & 11 & 139 \\
\hline & & & & $2.3 \%$ & $1.2 \%$ & $1.5 \%$ & $1.3 \%$ & $1.6 \%$ & $2.6 \%$ & $2.8 \%$ & $3.8 \%$ & $1.7 \%$ & $2.0 \%$ & $2.1 \%$ \\
\hline
\end{tabular}




\section{Internal Control Factors in SOX Section 404 MW Disclosures Accelerated Filers}

\begin{tabular}{|c|c|c|c|}
\hline MW Types Reported & $\begin{array}{c}\text { Negative } \\
\mathrm{N}=893\end{array}$ & $\begin{array}{c}\text { No Surprise } \\
\mathrm{N}=253\end{array}$ & p-value \\
\hline Accounting documentation, policy and/or procedures (17) & 89.2 & 87.4 & 0.398 \\
\hline Material and/or numerous auditor /YE adjustments (4) & 60.5 & 56.1 & 0.214 \\
\hline Accounting personnel resources, competency/training (44) & 45.8 & 57.7 & 0.001 \\
\hline Tax expense/benefit/deferral/other (FAS 109) issues (41) & 28.2 & 28.9 & 0.844 \\
\hline Revenue recognition issues (39) & 26.1 & 36.8 & 0.001 \\
\hline Restatement or non-reliance of company filings (5) & 24.5 & 32.8 & 0.008 \\
\hline Inventory, vendor and cost of sales issues (32) & 21.2 & 29.2 & 0.007 \\
\hline Information technology, software, security \& access issues (22) & 19.8 & 26.1 & 0.031 \\
\hline Liabilities, payables, reserves and accrual estimate failures (33) & 18.6 & 23.3 & 0.095 \\
\hline Untimely or inadequate account reconciliations (12) & 17.5 & 18.6 & 0.684 \\
\hline Journal entry control issues (76) & 16.8 & 26.1 & 0.001 \\
\hline Non-routine transaction control issues (77) & 16.6 & 19.0 & 0.371 \\
\hline PPE, intangible or fixed asset (value/diminution) issues (16) & 15.7 & 20.2 & 0.092 \\
\hline Accounts/loans receivable, investments \& cash issues (15) & 14.2 & 21.3 & 0.006 \\
\hline Segregations of duties/ design of controls (personnel) (42) & 13.4 & 19.0 & 0.028 \\
\hline Foreign, related party, affiliated and/or subsid issues (38) & 12.8 & 16.2 & 0.158 \\
\hline Unspecified/unidentified/inapplicable FASB/GAAP issues (68) & 10.8 & 15.0 & 0.062 \\
\hline Acquisition, merger, disposal or reorganization issues (35) & 10.5 & 8.3 & 0.299 \\
\hline Lease, FAS 5, legal, contingency \& commit issues (3) & 9.9 & 8.7 & 0.581 \\
\hline Deferred, stock-based or executive comp issues (27) & 9.1 & 13.4 & 0.041 \\
\hline Expense recording (payroll, SG\&A) issues (29) & 8.1 & 13.0 & 0.015 \\
\hline Fin statement, footnote, US GAAP conversion, segment disclosure (40) & 7.5 & 9.5 & 0.303 \\
\hline Inadequate disclosure controls (timely, accuracy, completeness) (9) & 7.4 & 10.7 & 0.092 \\
\hline Lease, leasehold \& FAS 13 (98) (subcategory) issues (73) & 7.3 & 5.9 & 0.457 \\
\hline Depreciation, depletion or amortization issues (28) & 6.3 & 4.7 & 0.364 \\
\hline Debt, quasi-debt, warrants \& equity (BCF) security issues (47) & 6.0 & 9.5 & 0.055 \\
\hline Capitalization of expenditures issues (14) & 5.5 & 2.4 & 0.041 \\
\hline Consolidation, (Fin46r/Off BS) \& foreign currency translation issues (24) & 5.5 & 6.7 & 0.458 \\
\hline Intercompany/Investment w/ subsidiary/affiliate issues (8) & 3.6 & 4.0 & 0.783 \\
\hline Cash flow statement (FAS 95) classification errors (10) & 3.2 & 4.3 & 0.400 \\
\hline Senior management competency, tone, reliability issues (13) & 3.2 & 8.3 & 0.001 \\
\hline Ethical or compliance issues with personnel (21) & 3.1 & 6.3 & 0.020 \\
\hline Financial derivatives/hedging (FAS 133) accounting issues (30) & 2.7 & 2.8 & 0.946 \\
\hline Insufficient or non-existent internal audit function (18) & 2.4 & 4.3 & 0.089 \\
\hline Treasury Control Issues (57) & 2.2 & 1.6 & 0.519 \\
\hline Ineffective regulatory compliance issues (19) & 1.3 & 1.2 & 0.846 \\
\hline Pension and other post-retirement benefit issues (80) & 1.3 & 2.0 & 0.463 \\
\hline Balance sheet classification of asset issues (23) & 1.2 & 0.4 & 0.249 \\
\hline Management/Board/Audit Committee investigation (s) (7) & 1.1 & 1.2 & 0.931 \\
\hline Income statement classification, margin and EPS issues (36) & 1.1 & 3.6 & 0.007 \\
\hline Ineffective, non-existent or understaffed audit committee (11) & 1.0 & 1.2 & 0.807 \\
\hline Asset Retirement Obligation Issues (81) & 0.9 & 1.2 & 0.677 \\
\hline Gain or loss recognition issues (31) & 0.8 & 1.2 & 0.545 \\
\hline Restatement of previous 404 disclosures (43) & 0.6 & 0.0 & 0.234 \\
\hline Debt and/or equity classification issues (25) & 0.2 & 0.8 & 0.178 \\
\hline Loan covenant violations/issues (34) & 0.1 & 0.4 & 0.342 \\
\hline
\end{tabular}


Table 3

Internal Control Factors in SOX Section 404 MW Disclosures Non-Accelerated Filers

\begin{tabular}{|c|c|c|c|}
\hline MW Types Reported & \begin{tabular}{|l|} 
Negative \\
$\mathrm{N}=575$
\end{tabular} & \begin{tabular}{|c} 
No Surprise \\
$\mathrm{N}=169$ \\
\end{tabular} & p-value \\
\hline Accounting documentation, policy and/or procedures (17) & 94.1 & 89.9 & 0.061 \\
\hline Accounting personnel resources, competency/training (44) & 57.9 & 60.9 & 0.482 \\
\hline Unspecified/unidentified/inapplicable FASB/GAAP issues (68) & 43.3 & 47.3 & 0.354 \\
\hline Material and/or numerous auditor /YE adjustments (4) & 42.1 & 30.8 & 0.008 \\
\hline Segregations of duties/ design of controls (personnel) (42) & 34.1 & 41.4 & 0.081 \\
\hline Inadequate disclosure controls (timely, accuracy, completeness) (9) & 15.0 & 11.8 & 0.308 \\
\hline Non-routine transaction control issues (77) & 14.8 & 17.8 & 0.348 \\
\hline Revenue recognition issues (39) & 13.2 & 14.2 & 0.742 \\
\hline Restatement or non-reliance of company filings (5) & 13.0 & 16.0 & 0.330 \\
\hline Information technology, software, security $\&$ access issues (22) & 12.5 & 22.5 & 0.001 \\
\hline Tax expense/benefit/deferral/other (FAS 109) issues (41) & 12.0 & 11.2 & 0.789 \\
\hline Accounts/loans receivable, investments \& cash issues (15) & 11.3 & 10.7 & 0.813 \\
\hline Inventory, vendor and cost of sales issues (32) & 11.0 & 13.6 & 0.344 \\
\hline Journal entry control issues (76) & 10.1 & 16.0 & 0.035 \\
\hline PPE, intangible or fixed asset (value/diminution) issues (16) & 8.9 & 8.3 & 0.813 \\
\hline Debt, quasi-debt, warrants \& equity (BCF) security issues (47) & 8.9 & 8.9 & 0.998 \\
\hline Liabilities, payables, reserves and accrual estimate failures (33) & 8.7 & 11.2 & 0.316 \\
\hline Ineffective, non-existent or understaffed audit committee (11) & 8.5 & 7.1 & 0.554 \\
\hline Foreign, related party, affiliated and/or subsid issues (38) & 8.2 & 8.9 & 0.772 \\
\hline Untimely or inadequate account reconciliations (12) & 8.0 & 7.1 & 0.702 \\
\hline Deferred, stock-based or executive comp issues (27) & 5.6 & 5.3 & 0.905 \\
\hline Expense recording (payroll, SG\&A) issues (29) & 5.2 & 8.9 & 0.080 \\
\hline Acquisition, merger, disposal or reorganization issues (35) & 5.0 & 11.8 & 0.002 \\
\hline Treasury Control Issues (57) & 2.8 & 4.1 & 0.370 \\
\hline Ineffective regulatory compliance issues (19) & 2.4 & 2.4 & 0.960 \\
\hline Fin statement, footnote, US GAAP conversion, segment disclosure (40) & 2.4 & 4.7 & 0.121 \\
\hline Lease, FAS 5, legal, contingency \& commit issues (3) & 2.1 & 2.4 & 0.826 \\
\hline Consolidation, (Fin46r/Off BS) \& foreign currency translation issues (24) & 2.1 & 2.4 & 0.826 \\
\hline Senior management competency, tone, reliability issues (13) & 1.9 & 1.8 & 0.908 \\
\hline Insufficient or non-existent internal audit function (18) & 1.9 & 1.8 & 0.908 \\
\hline Intercompany/Investment w/ subsidiary/affiliate issues (8) & 1.7 & 1.8 & 0.976 \\
\hline Cash flow statement (FAS 95) classification errors (10) & 1.6 & 1.8 & 0.850 \\
\hline Capitalization of expenditures issues (14) & 1.6 & 3.6 & 0.107 \\
\hline Ethical or compliance issues with personnel (21) & 1.2 & 2.4 & 0.277 \\
\hline Asset Retirement Obligation Issues (81) & 1.2 & 1.2 & 0.973 \\
\hline Depreciation, depletion or amortization issues (28) & 1.0 & 4.1 & 0.007 \\
\hline Lease, leasehold \& FAS 13 (98) (subcategory) issues (73) & 1.0 & 1.2 & 0.878 \\
\hline
\end{tabular}


Table 4

Internal Control Factors in SOX Section 302 MW Disclosures Accelerated Filers

\begin{tabular}{|c|c|c|c|}
\hline Disclosure Control Issues & $\begin{array}{l}\text { Positive } \\
\mathrm{N}=325\end{array}$ & $\begin{array}{c}\text { No-surprise } \\
\mathrm{N}=253\end{array}$ & $\mathrm{p}$-value \\
\hline Journal entry control issues (76) & 96.6 & 97.2 & 0.672 \\
\hline Revenue recognition issues (39) & 20.0 & 36.0 & 0.000 \\
\hline Information technology, software, security \& access issues (22) & 16.6 & 29.6 & 0.000 \\
\hline Liabilities, payables, reserves and accrual estimate failures (33) & 15.7 & 25.7 & 0.003 \\
\hline Inventory, vendor and cost of sales issues (32) & 15.1 & 25.3 & 0.002 \\
\hline Tax expense/benefit/deferral/other (FAS 109) issues (41) & 15.1 & 25.3 & 0.002 \\
\hline Unspecified/unidentified/inapplicable FASB/GAAP issues (68) & 14.2 & 19.8 & 0.073 \\
\hline Deferred, stock-based or executive comp issues (27) & 13.8 & 14.2 & 0.896 \\
\hline Accounts/loans receivable, investments \& cash issues (15) & 10.8 & 20.9 & 0.001 \\
\hline Accounting documentation, policy and/or procedures (17) & 10.2 & 15.8 & 0.042 \\
\hline Debt, quasi-debt, warrants \& equity (BCF) security issues (47) & 9.5 & 10.7 & 0.653 \\
\hline PPE, intangible or fixed asset (value/diminution) issues (16) & 9.2 & 18.2 & 0.002 \\
\hline Cash flow statement (FAS 95) classification errors (10) & 8.3 & 5.5 & 0.198 \\
\hline Foreign, related party, affiliated and/or subsid issues (38) & 7.7 & 17.8 & 0.000 \\
\hline Expense recording (payroll, SG\&A) issues (29) & 6.8 & 10.7 & 0.095 \\
\hline Acquisition, merger, disposal or reorganization issues (35) & 6.8 & 10.3 & 0.130 \\
\hline Income statement classification, margin and EPS issues (36) & 6.5 & 3.2 & 0.072 \\
\hline Consolidation, (Fin46r/Off BS) \& foreign currency translation issues (24) & 5.8 & 5.1 & 0.713 \\
\hline Lease, FAS 5, legal, contingency \& commit issues (3) & 5.2 & 6.7 & 0.451 \\
\hline Financial derivatives/hedging (FAS 133) accounting issues (30) & 5.2 & 4.3 & 0.625 \\
\hline Insufficient or non-existent internal audit function (18) & 4.0 & 7.9 & 0.045 \\
\hline Lease, leasehold \& FAS 13 (98) (subcategory) issues (73) & 4.0 & 4.7 & 0.664 \\
\hline Intercompany/Investment w/ subsidiary/affiliate issues (8) & 2.8 & 5.1 & 0.140 \\
\hline Capitalization of expenditures issues (14) & 2.8 & 2.8 & 0.999 \\
\hline Depreciation, depletion or amortization issues (28) & 2.8 & 4.0 & 0.429 \\
\hline Debt and/or equity classification issues (25) & 2.5 & 1.6 & 0.462 \\
\hline Fin statement, footnote, US GAAP conversion, segment disclosure (40) & 2.5 & 6.7 & 0.013 \\
\hline Balance sheet classification of asset issues (23) & 1.5 & 1.2 & 0.720 \\
\hline Gain or loss recognition issues $(31)$ & 1.5 & 1.6 & 0.968 \\
\hline Asset Retirement Obligation Issues (81) & 1.2 & 0.8 & 0.606 \\
\hline Non-routine transaction control issues (77) & 0.9 & 2.0 & 0.283 \\
\hline Restatement of previous 404 disclosures (43) & 0.6 & 3.2 & 0.020 \\
\hline Pension and other post-retirement benefit issues ( 80$)$ & 0.6 & 1.6 & 0.257 \\
\hline
\end{tabular}




\section{Table 5}

Internal Control Factors in SOX Section 302 MW Disclosures

Non-Accelerated Filers

\begin{tabular}{|c|c|c|c|}
\hline Disclosure Control Issues & $\begin{array}{c}\text { Positive } \\
\mathrm{N}=139\end{array}$ & $\begin{array}{c}\text { No-surprise } \\
\mathrm{N}=169\end{array}$ & $\mathrm{p}$-value \\
\hline Journal entry control issues (76) & 94.2 & 94.7 & 0.871 \\
\hline Unspecified/unidentified/inapplicable FASB/GAAP issues (68) & 36.0 & 54.4 & 0.001 \\
\hline Revenue recognition issues (39) & 18.0 & 10.7 & 0.065 \\
\hline Debt, quasi-debt, warrants \& equity (BCF) security issues (47) & 15.8 & 10.7 & 0.180 \\
\hline Information technology, software, security \& access issues (22) & 11.5 & 20.1 & 0.042 \\
\hline Inventory, vendor and cost of sales issues (32) & 11.5 & 11.2 & 0.942 \\
\hline Tax expense/benefit/deferral/other (FAS 109) issues (41) & 10.8 & 10.7 & 0.969 \\
\hline Deferred, stock-based or executive comp issues (27) & 10.1 & 4.7 & 0.071 \\
\hline Foreign, related party, affiliated and/or subsid issues (38) & 10.1 & 5.3 & 0.116 \\
\hline Accounting documentation, policy and/or procedures (17) & 9.4 & 9.5 & 0.974 \\
\hline Liabilities, payables, reserves and accrual estimate failures (33) & 9.4 & 8.3 & 0.743 \\
\hline PPE, intangible or fixed asset (value/diminution) issues (16) & 7.9 & 5.3 & 0.361 \\
\hline Expense recording (payroll, SG\&A) issues (29) & 7.9 & 4.7 & 0.250 \\
\hline Accounts/loans receivable, investments $\&$ cash issues (15) & 7.2 & 7.7 & 0.870 \\
\hline Insufficient or non-existent internal audit function (18) & 6.5 & 11.2 & 0.149 \\
\hline Acquisition, merger, disposal or reorganization issues (35) & 5.8 & 9.5 & 0.228 \\
\hline Cash flow statement (FAS 95) classification errors (10) & 5.0 & 1.8 & 0.109 \\
\hline Lease, FAS 5, legal, contingency \& commit issues (3) & 2.9 & 2.4 & 0.781 \\
\hline Income statement classification, margin and EPS issues (36) & 2.9 & 3.6 & 0.742 \\
\hline Debt and/or equity classification issues (25) & 2.2 & 1.2 & 0.503 \\
\hline Financial derivatives/hedging (FAS 133) accounting issues (30) & 2.2 & 0.6 & 0.229 \\
\hline Gain or loss recognition issues (31) & 2.2 & 0.6 & 0.229 \\
\hline Intercompany/Investment w/ subsidiary/affiliate issues (8) & 1.4 & 0.6 & 0.454 \\
\hline Balance sheet classification of asset issues (23) & 1.4 & 0.6 & 0.454 \\
\hline Depreciation, depletion or amortization issues (28) & 1.4 & 3.0 & 0.375 \\
\hline Fin statement, footnote, US GAAP conversion, segment disclosure (40) & 1.4 & 5.3 & 0.068 \\
\hline Capitalization of expenditures issues (14) & 0.7 & 3.0 & 0.159 \\
\hline Consolidation, (Fin46r/Off BS) \& foreign currency translation issues (24) & 0.7 & 2.4 & 0.257 \\
\hline Lease, leasehold \& FAS 13 (98) (subcategory) issues (73) & 0.7 & 0.6 & 0.893 \\
\hline Pension and other post-retirement benefit issues (80) & 0.7 & 0.0 & 0.273 \\
\hline Restatement of previous 404 disclosures (43) & 0.0 & 1.8 & 0.116 \\
\hline
\end{tabular}


Table 6

Mean Values - Auditor Dismissals

Accelerated Filers

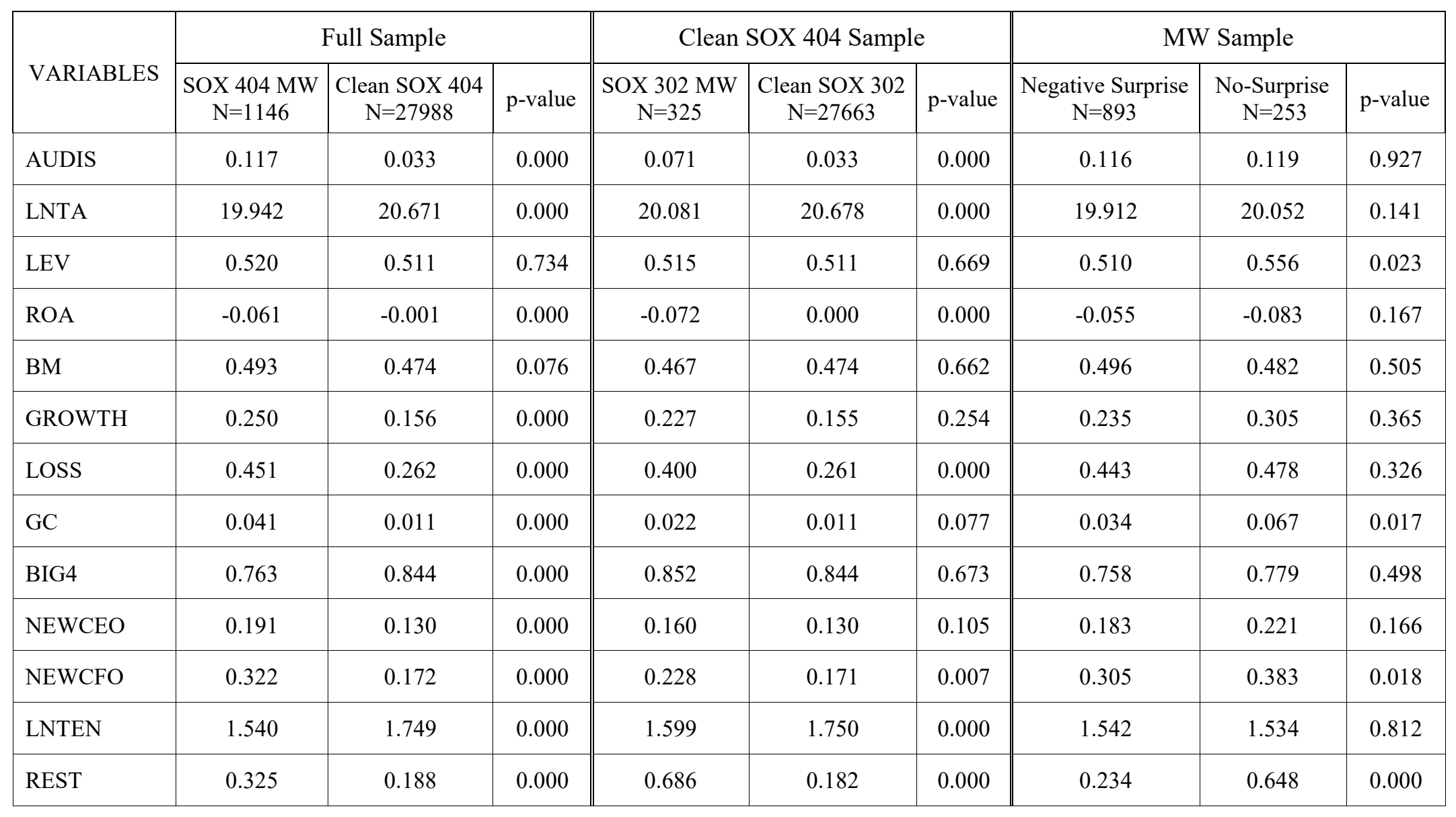


Table 7

MW Disclosures and Auditor Dismissals

Accelerated Filers

Panel A: Univariate Analysis

\begin{tabular}{|c|c|c||c|c||c|c|}
\hline \multirow{2}{*}{$\begin{array}{c}\text { Subsequent } \\
\text { Auditor } \\
\text { Dismissal }\end{array}$} & \multicolumn{2}{|c||}{ Full Sample } & \multicolumn{2}{c||}{ Clean SOX 404 Sample } & \multicolumn{2}{c|}{ MW Sample } \\
\cline { 2 - 7 } & Section 404 MW Disclosure & \multicolumn{2}{|c|}{ Section 302 MW Disclosure } & \multicolumn{2}{|c|}{ Surprise MW Disclosure } \\
\cline { 2 - 7 } & Yes & No & Yes & No & Yes & No \\
\hline \multirow{2}{*}{ Yes } & 134 & 927 & 23 & 904 & 104 & 30 \\
& $(11.7 \%)$ & $(3.3 \%)$ & $(7.1 \%)$ & $(3.3 \%)$ & $(11.7 \%)$ & $(11.9 \%)$ \\
\hline No & $\begin{array}{c}1012 \\
(88.3 \%)\end{array}$ & $\begin{array}{c}27061 \\
(96.7 \%)\end{array}$ & $\begin{array}{c}302 \\
(92.9 \%)\end{array}$ & $\begin{array}{c}26759 \\
(96.7 \%)\end{array}$ & $\begin{array}{c}789 \\
(88.3 \%)\end{array}$ & $\begin{array}{c}223 \\
(88.1 \%)\end{array}$ \\
\hline & $\chi^{2}=220.35, \mathrm{p}$-value: $<.0001$ & $\chi^{2}=14.55, \mathrm{p}$-value: $<.001$ & $\chi^{2}=0.01, \mathrm{p}$-value: 0.93 \\
\hline
\end{tabular}

Panel B: Regression Analysis - Accelerated Filers

\begin{tabular}{|c|c|c|c|c|c|c|}
\hline \multirow{2}{*}{ VARIABLES } & \multicolumn{2}{|c|}{ Full Sample } & \multicolumn{2}{|c|}{ Clean SOX 404 Sample } & \multicolumn{2}{|c|}{ MW Sample } \\
\hline & Coefficient & p-value & Coefficient & p-value & Coefficient & p-value \\
\hline CONSTANT & -0.492 & 0.307 & -0.622 & 0.225 & 0.295 & 0.849 \\
\hline MW & 1.033 & 0.000 & & & & \\
\hline PSURP & & & 0.587 & 0.009 & & \\
\hline SURP & & & & & 0.128 & 0.602 \\
\hline LNTA & -0.179 & 0.000 & -0.181 & 0.000 & -0.110 & 0.172 \\
\hline LEV & 0.249 & 0.060 & 0.250 & 0.079 & 0.069 & 0.855 \\
\hline ROA & 0.313 & 0.098 & 0.330 & 0.109 & 0.129 & 0.795 \\
\hline $\mathrm{BM}$ & 0.259 & 0.000 & 0.298 & 0.000 & -0.051 & 0.812 \\
\hline GROWTH & -0.160 & 0.014 & -0.190 & 0.011 & -0.073 & 0.620 \\
\hline LOSS & 0.262 & 0.003 & 0.287 & 0.003 & 0.084 & 0.712 \\
\hline GC & 0.030 & 0.904 & 0.297 & 0.261 & -0.873 & 0.179 \\
\hline BIG4 & -0.133 & 0.137 & -0.160 & 0.098 & -0.050 & 0.841 \\
\hline NEWCEO & -0.071 & 0.453 & -0.082 & 0.422 & -0.005 & 0.984 \\
\hline NEWCFO & 0.124 & 0.119 & 0.159 & 0.065 & -0.062 & 0.763 \\
\hline LNTEN & 0.022 & 0.676 & 0.043 & 0.446 & -0.088 & 0.553 \\
\hline REST & 0.277 & 0.000 & 0.236 & 0.004 & 0.425 & 0.046 \\
\hline Industry Dummies & \multicolumn{2}{|c|}{ Included } & \multicolumn{2}{|c|}{ Included } & \multicolumn{2}{|c|}{ Included } \\
\hline Year Dummies & \multicolumn{2}{|c|}{ Included } & \multicolumn{2}{|c|}{ Included } & \multicolumn{2}{|c|}{ Included } \\
\hline $\mathrm{N}$ & \multicolumn{2}{|c|}{29134} & \multicolumn{2}{|c|}{27988} & \multicolumn{2}{|c|}{1146} \\
\hline Chi-square & \multicolumn{2}{|c|}{373.5} & \multicolumn{2}{|c|}{245.8} & \multicolumn{2}{|c|}{27.66} \\
\hline p-value & \multicolumn{2}{|c|}{0.000} & \multicolumn{2}{|c|}{0.000} & \multicolumn{2}{|c|}{0.536} \\
\hline Pseudo R2 & \multicolumn{2}{|c|}{0.041} & \multicolumn{2}{|c|}{0.030} & \multicolumn{2}{|c|}{0.034} \\
\hline
\end{tabular}


Table 8

Mean Values - Auditor Dismissals

Non-Accelerated Filers

\begin{tabular}{|c|c|c|c|c|c|c|c|c|c|}
\hline \multirow{2}{*}{ VARIABLES } & \multicolumn{3}{|c|}{ Full Sample } & \multicolumn{3}{|c|}{ Clean SOX 404 Sample } & \multicolumn{3}{|c|}{ MW Sample } \\
\hline & $\begin{array}{c}\text { SOX } 404 \mathrm{MW} \\
\mathrm{N}=744\end{array}$ & $\begin{array}{c}\text { Clean SOX } 404 \\
N=6749\end{array}$ & p-value & $\begin{array}{c}\text { SOX } 302 \mathrm{MW} \\
\mathrm{N}=139\end{array}$ & $\begin{array}{c}\text { Clean SOX } 302 \\
\mathrm{~N}=6610\end{array}$ & p-value & $\begin{array}{c}\text { Negative Surprise } \\
\mathrm{N}=575\end{array}$ & $\begin{array}{c}\text { No-Surprise } \\
\mathrm{N}=169\end{array}$ & p-value \\
\hline AUDIS & 0.120 & 0.057 & 0.000 & 0.158 & 0.055 & 0.000 & 0.117 & 0.130 & 0.631 \\
\hline LNTA & 17.246 & 17.874 & 0.000 & 17.524 & 17.881 & 0.033 & 17.218 & 17.342 & 0.345 \\
\hline LEV & 0.732 & 0.538 & 0.000 & 0.670 & 0.535 & 0.000 & 0.736 & 0.717 & 0.763 \\
\hline ROA & -0.414 & -0.213 & 0.000 & -0.375 & -0.209 & 0.000 & -0.408 & -0.434 & 0.276 \\
\hline $\mathrm{BM}$ & 0.319 & 0.650 & 0.000 & 0.366 & 0.656 & 0.000 & 0.328 & 0.291 & 0.524 \\
\hline GROWTH & 0.310 & 0.117 & 0.002 & 0.235 & 0.114 & 0.272 & 0.305 & 0.329 & 0.338 \\
\hline LOSS & 0.778 & 0.627 & 0.000 & 0.734 & 0.625 & 0.009 & 0.774 & 0.793 & 0.602 \\
\hline GC & 0.388 & 0.142 & 0.000 & 0.237 & 0.140 & 0.001 & 0.386 & 0.396 & 0.808 \\
\hline BIG4 & 0.227 & 0.334 & 0.000 & 0.381 & 0.333 & 0.234 & 0.216 & 0.266 & 0.168 \\
\hline NEWCEO & 0.210 & 0.170 & 0.007 & 0.158 & 0.170 & 0.704 & 0.214 & 0.195 & 0.601 \\
\hline NEWCFO & 0.309 & 0.189 & 0.000 & 0.223 & 0.189 & 0.306 & 0.322 & 0.266 & 0.171 \\
\hline LNTEN & 1.240 & 1.462 & 0.000 & 1.361 & 1.464 & 0.090 & 1.241 & 1.238 & 0.996 \\
\hline REST & 0.249 & 0.188 & 0.000 & 0.561 & 0.180 & 0.000 & 0.209 & 0.385 & 0.000 \\
\hline
\end{tabular}


Table 9

Surprise MW Disclosures and Auditor Dismissal

Non-Accelerated Filers

Panel A: Univariate Analysis

\begin{tabular}{|c|c|c||c|c||c|c|}
\hline \multirow{2}{*}{$\begin{array}{c}\text { Subsequent } \\
\text { Auditor } \\
\text { Dismissal }\end{array}$} & \multicolumn{2}{|c||}{ Full Sample } & \multicolumn{2}{c||}{ Clean SOX 404 Sample } & \multicolumn{2}{c|}{ MW Sample } \\
\cline { 2 - 7 } & Section 404 MW Disclosure & \multicolumn{2}{|c|}{ Section 302 MW Disclosure } & \multicolumn{2}{|c|}{ Surprise MW Disclosure } \\
\cline { 2 - 7 } & Yes & No & Yes & No & Yes & No \\
\hline Yes & $\begin{array}{c}89 \\
(12.0 \%)\end{array}$ & $\begin{array}{c}388 \\
(5.8 \%)\end{array}$ & $\begin{array}{c}22 \\
(15.8 \%)\end{array}$ & $\begin{array}{c}366 \\
(5.5 \%)\end{array}$ & $\begin{array}{c}67 \\
(11.7 \%)\end{array}$ & $\begin{array}{c}23 \\
(13.0 \%)\end{array}$ \\
\hline No & $\begin{array}{c}655 \\
(88.0 \%)\end{array}$ & $\begin{array}{c}6361 \\
(94.2 \%)\end{array}$ & $\begin{array}{c}117 \\
(84.2 \%)\end{array}$ & $\begin{array}{c}6244 \\
(94.5 \%)\end{array}$ & $\begin{array}{c}508 \\
(88.3 \%)\end{array}$ & $\begin{array}{c}147 \\
(87.0 \%)\end{array}$ \\
\hline & \multicolumn{2}{|c|}{$\chi^{2}=43.40, \mathrm{p}$-value: $<.0001$} & $\chi^{2}=26.60, \mathrm{p}$-value: $<.0001$ & $\chi^{2}=0.23, \mathrm{p}$-value: 0.63 \\
\hline
\end{tabular}

Panel B: Regression Analysis

\begin{tabular}{|c|c|c|c|c|c|c|}
\hline \multirow{2}{*}{ VARIABLES } & \multicolumn{2}{|c|}{ Full Sample } & \multicolumn{2}{|c|}{ Clean SOX 404 Sample } & \multicolumn{2}{|c|}{ MW Sample } \\
\hline & Coefficient & p-value & Coefficient & p-value & Coefficient & p-value \\
\hline CONSTANT & -0.449 & 0.520 & -0.988 & 0.201 & 2.053 & 0.295 \\
\hline MW & 0.684 & 0.000 & & & & \\
\hline PSURP & & & 1.053 & 0.000 & & \\
\hline SURP & & & & & -0.183 & 0.517 \\
\hline LNTA & -0.193 & 0.000 & -0.159 & 0.000 & -0.364 & 0.000 \\
\hline LEV & -0.062 & 0.667 & -0.103 & 0.536 & 0.042 & 0.886 \\
\hline $\mathrm{ROA}$ & 0.406 & 0.012 & 0.457 & 0.017 & 0.281 & 0.391 \\
\hline $\mathrm{BM}$ & 0.016 & 0.810 & -0.016 & 0.828 & 0.257 & 0.125 \\
\hline GROWTH & -0.011 & 0.866 & 0.007 & 0.925 & -0.030 & 0.799 \\
\hline LOSS & 0.227 & 0.071 & 0.204 & 0.140 & 0.460 & 0.194 \\
\hline $\mathrm{GC}$ & 0.322 & 0.025 & 0.501 & 0.002 & -0.344 & 0.255 \\
\hline BIG4 & 0.915 & 0.000 & 0.791 & 0.000 & 1.518 & 0.000 \\
\hline NEWCEO & 0.201 & 0.092 & 0.146 & 0.276 & 0.504 & 0.074 \\
\hline NEWCFO & 0.380 & 0.001 & 0.420 & 0.001 & 0.222 & 0.401 \\
\hline LNTEN & 0.071 & 0.303 & 0.108 & 0.160 & 0.018 & 0.911 \\
\hline REST & 0.131 & 0.275 & 0.109 & 0.422 & -0.206 & 0.494 \\
\hline Industry Dummies & \multicolumn{2}{|c|}{ Included } & \multicolumn{2}{|c|}{ Included } & \multicolumn{2}{|c|}{ Included } \\
\hline Year Dummies & \multicolumn{2}{|c|}{ Included } & \multicolumn{2}{|c|}{ Included } & \multicolumn{2}{|c|}{ Included } \\
\hline $\mathrm{N}$ & \multicolumn{2}{|c|}{7493} & \multicolumn{2}{|c|}{6749} & \multicolumn{2}{|c|}{744} \\
\hline Chi-square & \multicolumn{2}{|c|}{157.1} & \multicolumn{2}{|c|}{116.7} & \multicolumn{2}{|c|}{47.19} \\
\hline p-value & \multicolumn{2}{|c|}{0.000} & \multicolumn{2}{|c|}{0.000} & \multicolumn{2}{|c|}{0.007} \\
\hline Pseudo R2 & \multicolumn{2}{|c|}{0.0442} & \multicolumn{2}{|c|}{0.0393} & \multicolumn{2}{|c|}{0.0866} \\
\hline
\end{tabular}


Table 10

Mean Values - CFO Turnover

Accelerated Filers

\begin{tabular}{|c|c|c|c|c|c|c|c|c|c|}
\hline \multirow{2}{*}{ VARIABLES } & \multicolumn{3}{|c|}{ Full Sample } & \multicolumn{3}{|c|}{ Clean SOX 404 Sample } & \multicolumn{3}{|c|}{ MW Sample } \\
\hline & $\begin{array}{c}\text { SOX } 404 \mathrm{MW} \\
\mathrm{N}=1146\end{array}$ & $\begin{array}{c}\text { Clean SOX } 404 \\
\mathrm{~N}=27988\end{array}$ & $\mathrm{p}$-value & \begin{tabular}{|c|} 
SOX $302 \mathrm{MW}$ \\
$\mathrm{N}=325$ \\
\end{tabular} & $\begin{array}{c}\text { Clean SOX } 302 \\
\mathrm{~N}=27663 \\
\end{array}$ & p-value & $\begin{array}{c}\text { Negative Surprise } \\
\mathrm{N}=893\end{array}$ & $\begin{array}{c}\text { No-Surprise } \\
\mathrm{N}=253\end{array}$ & p-value \\
\hline CFOCHG & 0.265 & 0.153 & 0.000 & 0.188 & 0.153 & 0.080 & 0.254 & 0.304 & 0.111 \\
\hline ROA & -0.061 & -0.001 & 0.000 & -0.072 & 0.000 & 0.000 & -0.055 & -0.083 & 0.167 \\
\hline SEGS & 2.353 & 2.531 & 0.002 & 2.249 & 2.534 & 0.003 & 2.355 & 2.344 & 0.970 \\
\hline REST & 0.325 & 0.188 & 0.000 & 0.686 & 0.182 & 0.000 & 0.234 & 0.648 & 0.000 \\
\hline M\&A & 0.225 & 0.224 & 0.957 & 0.206 & 0.225 & 0.426 & 0.216 & 0.257 & 0.171 \\
\hline SIZEQ & 4.627 & 3.832 & 0.000 & 4.443 & 3.825 & 0.000 & 4.667 & 4.486 & 0.170 \\
\hline DIS & 0.546 & 0.343 & 0.000 & 0.505 & 0.341 & 0.000 & 0.535 & 0.585 & 0.161 \\
\hline GROWTH & 0.250 & 0.156 & 0.000 & 0.227 & 0.155 & 0.254 & 0.235 & 0.305 & 0.365 \\
\hline CEO_CHAIR & 0.493 & 0.524 & 0.038 & 0.477 & 0.525 & 0.086 & 0.517 & 0.407 & 0.002 \\
\hline
\end{tabular}


Table 11

Surprise MW Disclosures and CFO Turnover

Accelerated Filers

Panel A: Univariate Analysis

\begin{tabular}{|c|c|c||c|c||c|c|}
\hline \multirow{2}{*}{$\begin{array}{l}\text { Subsequent } \\
\begin{array}{l}\text { Auditor } \\
\text { Dismissal }\end{array}\end{array}$} & \multicolumn{2}{|c||}{ Full Sample } & \multicolumn{2}{c||}{ Clean SOX 404 Sample } & \multicolumn{2}{c|}{ MW Sample } \\
\cline { 2 - 7 } & Section 404 MW Disclosure & \multicolumn{2}{|c|}{ Section 302 MW Disclosure } & \multicolumn{2}{|c|}{ Surprise MW Disclosure } \\
\cline { 2 - 7 } & Yes & No & Yes & No & Yes & No \\
\hline Yes & $\begin{array}{c}304 \\
(26.5 \%)\end{array}$ & $\begin{array}{c}4282 \\
(15.3 \%)\end{array}$ & $\begin{array}{c}61 \\
(18.8 \%)\end{array}$ & $\begin{array}{c}4221 \\
(15.3 \%)\end{array}$ & $\begin{array}{c}227 \\
(25.4 \%)\end{array}$ & $\begin{array}{c}77 \\
(30.4 \%)\end{array}$ \\
\hline No & $\begin{array}{c}842 \\
(73.5 \%)\end{array}$ & $\begin{array}{c}23706 \\
(84.7 \%)\end{array}$ & $\begin{array}{c}264 \\
(81.2 \%)\end{array}$ & $\begin{array}{c}23442 \\
(84.7 \%)\end{array}$ & $\begin{array}{c}666 \\
(74.6 \%)\end{array}$ & $\begin{array}{c}176 \\
(69.6 \%)\end{array}$ \\
\hline & $\chi^{2}=104.64, p$-value: $<.0001$ & $\chi^{2}=3.06, p$-value: 0.08 & $\chi^{2}=2.54, p$-value: 0.11 \\
\hline
\end{tabular}

Panel B: Regression Analysis -Accelerated Filers

\begin{tabular}{|c|c|c|c|c|c|c|}
\hline \multirow{2}{*}{ VARIABLES } & \multicolumn{2}{|c|}{ Full Sample } & \multicolumn{2}{|c|}{ Clean SOX 404 Sample } & \multicolumn{2}{|c|}{ MW Sample } \\
\hline & Coefficient & p-value & Coefficient & p-value & Coefficient & $\mathrm{p}$-value \\
\hline CONSTANT & -1.750 & 0.000 & -1.755 & 0.000 & -1.057 & 0.026 \\
\hline MW & 0.605 & 0.000 & & & & \\
\hline PSURP & & & 0.143 & 0.327 & & \\
\hline SURP & & & & & -0.288 & 0.102 \\
\hline $\mathrm{ROA}$ & -0.273 & 0.003 & -0.313 & 0.001 & 0.134 & 0.689 \\
\hline LEV & 0.052 & 0.426 & 0.090 & 0.188 & -0.381 & 0.146 \\
\hline SEGS & 0.003 & 0.755 & 0.003 & 0.801 & 0.013 & 0.783 \\
\hline REST & 0.068 & 0.093 & 0.066 & 0.119 & -0.022 & 0.890 \\
\hline M\&A & 0.031 & 0.463 & 0.025 & 0.561 & 0.106 & 0.558 \\
\hline SIZEQ & -0.044 & 0.000 & -0.050 & 0.000 & 0.048 & 0.299 \\
\hline YOUNG & -0.161 & 0.020 & -0.161 & 0.026 & -0.196 & 0.418 \\
\hline DIS & 0.226 & 0.000 & 0.226 & 0.000 & 0.226 & 0.151 \\
\hline GROWTH & 0.055 & 0.073 & 0.055 & 0.090 & 0.058 & 0.573 \\
\hline CEO_CHAIR & -0.142 & 0.000 & -0.153 & 0.000 & -0.005 & 0.972 \\
\hline Industry Dummies & \multicolumn{2}{|c|}{ Included } & \multicolumn{2}{|c|}{ Included } & \multicolumn{2}{|c|}{ Included } \\
\hline Year Dummies & \multicolumn{2}{|c|}{ Included } & \multicolumn{2}{|c|}{ Included } & \multicolumn{2}{|c|}{ Included } \\
\hline $\mathrm{N}$ & \multicolumn{2}{|c|}{29134} & \multicolumn{2}{|c|}{27988} & \multicolumn{2}{|c|}{1146} \\
\hline Chi-square & \multicolumn{2}{|c|}{301.1} & \multicolumn{2}{|c|}{211.6} & \multicolumn{2}{|c|}{25.92} \\
\hline $\mathrm{p}$-value & \multicolumn{2}{|c|}{0.000} & \multicolumn{2}{|c|}{0.000} & \multicolumn{2}{|c|}{0.523} \\
\hline Pseudo R2 & \multicolumn{2}{|c|}{0.0119} & \multicolumn{2}{|c|}{0.00884} & \multicolumn{2}{|c|}{0.0195} \\
\hline
\end{tabular}


Table 12

Mean Values- CFO Turnover

Non-Accelerated Filers

\begin{tabular}{|c|c|c|c|c|c|c|c|c|c|}
\hline \multirow{2}{*}{ VARIABLES } & \multicolumn{3}{|c|}{ Full Sample } & \multicolumn{3}{|c|}{ Clean SOX 404 Sample } & \multicolumn{3}{|c|}{ MW Sample } \\
\hline & $\begin{array}{c}\text { SOX } 404 \mathrm{MW} \\
\mathrm{N}=744\end{array}$ & $\begin{array}{c}\text { Clean SOX } 404 \\
N=6749\end{array}$ & $\mathrm{p}$-value & $\begin{array}{c}\text { SOX } 302 \mathrm{MW} \\
\quad \mathrm{N}=139\end{array}$ & $\begin{array}{c}\text { Clean SOX } 302 \\
\quad \mathrm{~N}=6610\end{array}$ & p-value & $\begin{array}{l}\text { Negative Surprise } \\
\qquad \mathrm{N}=575\end{array}$ & $\begin{array}{c}\text { No-Surprise } \\
\mathrm{N}=169\end{array}$ & p-value \\
\hline CFOCHG & 0.228 & 0.163 & 0.000 & 0.158 & 0.163 & 0.883 & 0.228 & 0.231 & 0.936 \\
\hline ROA & -0.414 & -0.213 & 0.000 & -0.375 & -0.209 & 0.000 & -0.408 & -0.434 & 0.276 \\
\hline LEV & 0.732 & 0.538 & 0.000 & 0.670 & 0.535 & 0.000 & 0.736 & 0.717 & 0.763 \\
\hline SEGS & 1.426 & 1.720 & 0.000 & 1.446 & 1.726 & 0.002 & 1.456 & 1.325 & 0.212 \\
\hline REST & 0.249 & 0.188 & 0.000 & 0.561 & 0.180 & 0.000 & 0.209 & 0.385 & 0.000 \\
\hline M\&A & 0.145 & 0.111 & 0.005 & 0.151 & 0.110 & 0.127 & 0.139 & 0.166 & 0.390 \\
\hline SIZEQ & 7.239 & 6.764 & 0.000 & 7.036 & 6.758 & 0.047 & 7.263 & 7.160 & 0.309 \\
\hline YOUNG & 0.269 & 0.076 & 0.000 & 0.259 & 0.072 & 0.000 & 0.245 & 0.349 & 0.007 \\
\hline DIS & 0.853 & 0.716 & 0.000 & 0.799 & 0.715 & 0.030 & 0.850 & 0.864 & 0.664 \\
\hline GROWTH & 0.310 & 0.117 & 0.002 & 0.235 & 0.114 & 0.272 & 0.305 & 0.329 & 0.338 \\
\hline CEO_CHAIR & 0.362 & 0.364 & 0.906 & 0.302 & 0.365 & 0.127 & 0.372 & 0.325 & 0.267 \\
\hline
\end{tabular}


Table 13

Surprise MW Disclosures and CFO Turnover Non-Accelerated Filers

Panel A: Univariate Analysis

\begin{tabular}{|c|c|c||c|c||c|c|}
\hline \multirow{2}{*}{$\begin{array}{c}\text { Subsequent } \\
\text { Auditor } \\
\text { Dismissal }\end{array}$} & \multicolumn{2}{|c||}{ Full Sample } & \multicolumn{2}{c||}{ Clean SOX 404 Sample } & \multicolumn{2}{c|}{ MW Sample } \\
\cline { 2 - 7 } & Section 404 MW Disclosure & Section 302 MW Disclosure & Surprise MW Disclosure \\
\cline { 2 - 7 } & Yes & No & Yes & No & Yes & No \\
\hline Yes & $\begin{array}{c}170 \\
(22.9 \%)\end{array}$ & $\begin{array}{c}1099 \\
(16.3 \%)\end{array}$ & $\begin{array}{c}22 \\
(15.8 \%)\end{array}$ & $\begin{array}{c}1077 \\
(16.3 \%)\end{array}$ & $\begin{array}{c}131 \\
(22.8)\end{array}$ & $\begin{array}{c}39 \\
(23.1 \%)\end{array}$ \\
\hline No & $\begin{array}{c}574 \\
(77.1 \%)\end{array}$ & $\begin{array}{c}5650 \\
(83.7 \%)\end{array}$ & $\begin{array}{c}117 \\
(84.2 \%)\end{array}$ & $\begin{array}{c}5533 \\
(83.7 \%)\end{array}$ & $\begin{array}{c}444 \\
(77.2 \%)\end{array}$ & $\begin{array}{c}130 \\
(76.9 \%)\end{array}$ \\
\hline & \multicolumn{2}{|c|}{$\chi^{2}=20.53, \mathrm{p}$-value: $<.0001$} & $\chi^{2}=0.02, \mathrm{p}$-value: 0.88 & $\chi^{2}=0.01, \mathrm{p}$-value: 0.94 \\
\hline
\end{tabular}

Panel B: Regression Analysis - Non-Accelerated Filers

\begin{tabular}{|c|c|c|c|c|c|c|}
\hline \multirow{2}{*}{ VARIABLES } & \multicolumn{2}{|c|}{ Full Sample } & \multicolumn{2}{|c|}{ Clean SOX 404 Sample } & \multicolumn{2}{|c|}{ MW Sample } \\
\hline & Coefficient & p-value & Coefficient & p-value & Coefficient & $\mathrm{p}$-value \\
\hline CONSTANT & -1.897 & 0.000 & -1.917 & 0.000 & -1.374 & 0.049 \\
\hline MW & 0.248 & 0.013 & & & & \\
\hline PSURP & & & -0.253 & 0.297 & & \\
\hline SURP & & & & & -0.030 & 0.890 \\
\hline $\mathrm{ROA}$ & -0.426 & 0.000 & -0.450 & 0.000 & -0.310 & 0.156 \\
\hline LEV & -0.053 & 0.518 & -0.067 & 0.464 & 0.041 & 0.832 \\
\hline SEGS & -0.004 & 0.892 & -0.017 & 0.546 & 0.095 & 0.207 \\
\hline REST & 0.032 & 0.682 & 0.096 & 0.261 & -0.322 & 0.155 \\
\hline M\&A & 0.365 & 0.000 & 0.312 & 0.003 & 0.495 & 0.047 \\
\hline SIZEQ & -0.070 & 0.000 & -0.076 & 0.000 & -0.048 & 0.394 \\
\hline YOUNG & 0.174 & 0.091 & 0.253 & 0.034 & 0.025 & 0.908 \\
\hline DIS & 0.400 & 0.000 & 0.388 & 0.000 & 0.504 & 0.126 \\
\hline GROWTH & -0.041 & 0.342 & -0.106 & 0.043 & 0.118 & 0.134 \\
\hline CEO_CHAIR & -0.101 & 0.128 & -0.104 & 0.145 & -0.154 & 0.439 \\
\hline Industry Dummies & \multicolumn{2}{|c|}{ Included } & \multicolumn{2}{|c|}{ Included } & \multicolumn{2}{|c|}{ Included } \\
\hline Year Dummies & \multicolumn{2}{|c|}{ Included } & \multicolumn{2}{|c|}{ Included } & \multicolumn{2}{|c|}{ Included } \\
\hline $\mathrm{N}$ & \multicolumn{2}{|c|}{7493} & \multicolumn{2}{|c|}{6749} & \multicolumn{2}{|c|}{744} \\
\hline Chi-square & \multicolumn{2}{|c|}{161.6} & \multicolumn{2}{|c|}{137.7} & \multicolumn{2}{|c|}{32.63} \\
\hline p-value & \multicolumn{2}{|c|}{0.000} & \multicolumn{2}{|c|}{0.000} & \multicolumn{2}{|c|}{0.112} \\
\hline Pseudo R2 & \multicolumn{2}{|c|}{0.0237} & \multicolumn{2}{|c|}{0.023} & \multicolumn{2}{|c|}{0.0408} \\
\hline
\end{tabular}


Table 14

Mean Values - Shareholder Auditor Ratification Vote

Accelerated Filers

\begin{tabular}{|c|c|c|c|c|c|c|c|c|c|}
\hline \multirow{2}{*}{ VARIABLES } & \multicolumn{3}{|c|}{ Full Sample } & \multicolumn{3}{|c|}{ Clean SOX 404 Sample } & \multicolumn{3}{|c|}{ MW Sample } \\
\hline & $\begin{array}{c}\text { SOX } 404 \mathrm{MW} \\
\mathrm{N}=553\end{array}$ & $\begin{array}{c}\text { Clean SOX } 404 \\
\mathrm{~N}=19846\end{array}$ & p-value & $\begin{array}{c}\text { SOX } 302 \mathrm{MW} \\
\mathrm{N}=211\end{array}$ & $\begin{array}{c}\text { Clean SOX } 302 \\
\quad \mathrm{~N}=19635\end{array}$ & p-value & $\begin{array}{c}\text { Negative Surprise } \\
\mathrm{N}=421\end{array}$ & $\begin{array}{l}\text { No-Surprise } \\
\mathrm{N}=132\end{array}$ & $\mathrm{p}$-value \\
\hline BIG4 & 0.816 & 0.874 & 0.000 & 0.867 & 0.874 & 0.779 & 0.817 & 0.811 & 0.867 \\
\hline $\mathrm{GC}$ & 0.027 & 0.007 & 0.000 & 0.009 & 0.007 & 0.642 & 0.019 & 0.053 & 0.036 \\
\hline GROWTH & 0.260 & 0.147 & 0.001 & 0.196 & 0.146 & 0.745 & 0.245 & 0.306 & 0.881 \\
\hline LNTA & 20.216 & 20.883 & 0.000 & 20.203 & 20.890 & 0.000 & 20.221 & 20.200 & 0.924 \\
\hline LNTEN & 1.618 & 1.810 & 0.000 & 1.599 & 1.812 & 0.000 & 1.622 & 1.608 & 0.659 \\
\hline LOSS & 0.425 & 0.243 & 0.000 & 0.417 & 0.241 & 0.000 & 0.418 & 0.447 & 0.558 \\
\hline NASR & 0.202 & 0.227 & 0.000 & 0.207 & 0.227 & 0.087 & 0.210 & 0.177 & 0.126 \\
\hline REST & 0.331 & 0.183 & 0.000 & 0.668 & 0.178 & 0.000 & 0.238 & 0.629 & 0.000 \\
\hline ROA & -0.047 & 0.009 & 0.000 & -0.078 & 0.010 & 0.000 & -0.040 & -0.067 & 0.289 \\
\hline VOTE & -0.164 & -0.188 & 0.635 & -0.363 & -0.187 & 0.388 & -0.127 & -0.280 & 0.718 \\
\hline
\end{tabular}


Table 15

Surprise MW Disclosures and Shareholder Auditor Ratification Vote Accelerated Filers

Panel A: Univariate Analysis of VOTE

\begin{tabular}{|l|c||c||c|}
\hline & Full Sample & Clean SOX 404 Sample & MW Sample \\
\hline & Section 404 MW Disclosure & Section 302 MW Disclosure & Surprise MW Disclosure \\
\hline Yes & -0.164 & -0.363 & -0.127 \\
\hline No & -0.189 & -0.187 & -0.280 \\
\hline & $\mathrm{T}=-0.40, \mathrm{p}=0.69$ & $\mathrm{~T}=1.59, \mathrm{p}=0.11$ & $\mathrm{~T}=0.95, \mathrm{p}=0.34$ \\
\hline
\end{tabular}

Panel B: Regression Analysis

\begin{tabular}{|c|c|c|c|c|c|c|}
\hline \multirow{2}{*}{ VARIABLES } & \multicolumn{2}{|c|}{ Full Sample } & \multicolumn{2}{|c|}{ Clean SOX 404 Sample } & \multicolumn{2}{|c|}{ MW Sample } \\
\hline & Coefficient & p-value & Coefficient & p-value & Coefficient & $\mathrm{p}$-value \\
\hline CONSTANT & -3.288 & 0.000 & -3.277 & 0.000 & -3.700 & 0.001 \\
\hline MW & 0.149 & 0.005 & & & & \\
\hline PSURP & & & 0.029 & 0.728 & & \\
\hline SURP & & & & & 0.291 & 0.055 \\
\hline LNTA & 0.088 & 0.000 & 0.087 & 0.000 & 0.119 & 0.009 \\
\hline BIG4 & -0.255 & 0.000 & -0.250 & 0.000 & -0.370 & 0.034 \\
\hline NASR & 0.511 & 0.000 & 0.508 & 0.000 & 0.564 & 0.001 \\
\hline LNTEN & 0.511 & 0.000 & 0.512 & 0.000 & 0.434 & 0.000 \\
\hline $\mathrm{GC}$ & 0.679 & 0.000 & 0.700 & 0.000 & 0.584 & 0.143 \\
\hline REST & 0.036 & 0.104 & 0.023 & 0.317 & 0.405 & 0.003 \\
\hline LOSS & -0.063 & 0.018 & -0.062 & 0.021 & 0.021 & 0.886 \\
\hline GROWTH & -0.116 & 0.000 & -0.119 & 0.000 & -0.096 & 0.272 \\
\hline $\mathrm{ROA}$ & -0.187 & 0.003 & -0.174 & 0.006 & -0.266 & 0.388 \\
\hline $\begin{array}{l}\text { Industry } \\
\text { Dummies }\end{array}$ & \multicolumn{2}{|c|}{ Included } & \multicolumn{2}{|c|}{ Included } & \multicolumn{2}{|c|}{ Included } \\
\hline Year Dummies & \multicolumn{2}{|c|}{ Included } & \multicolumn{2}{|c|}{ Included } & \multicolumn{2}{|c|}{ Included } \\
\hline $\mathrm{N}$ & \multicolumn{2}{|c|}{20399} & \multicolumn{2}{|c|}{19846} & \multicolumn{2}{|c|}{553} \\
\hline $\mathrm{F}$ & \multicolumn{2}{|c|}{116.8} & \multicolumn{2}{|c|}{115.3} & \multicolumn{2}{|c|}{2.907} \\
\hline $\mathrm{p}$ & \multicolumn{2}{|c|}{0.000} & \multicolumn{2}{|c|}{0.000} & \multicolumn{2}{|c|}{0.000} \\
\hline Adjusted R2 & \multicolumn{2}{|c|}{0.129} & \multicolumn{2}{|c|}{0.13} & \multicolumn{2}{|c|}{0.082} \\
\hline
\end{tabular}


Table 16

Mean Values - Shareholder Auditor Ratification Vote

Non-Accelerated Filers

\begin{tabular}{|c|c|c|c|c|c|c|c|c|c|}
\hline \multirow{2}{*}{ VARIABLES } & \multicolumn{3}{|c|}{ Full Sample } & \multicolumn{3}{|c|}{ Clean SOX 404 Sample } & \multicolumn{3}{|c|}{ MW Sample } \\
\hline & $\begin{array}{c}\text { SOX } 404 \mathrm{MW} \\
\mathrm{N}=166\end{array}$ & $\begin{array}{c}\text { Clean SOX } 404 \\
\mathrm{~N}=3015\end{array}$ & $\mathrm{p}$-value & $\begin{array}{c}\text { SOX } 302 \mathrm{MW} \\
\mathrm{N}=45\end{array}$ & $\begin{array}{c}\text { Clean SOX } 302 \\
\mathrm{~N}=2970\end{array}$ & $\mathrm{p}$-value & $\begin{array}{c}\text { Negative Surprise } \\
\mathrm{N}=127\end{array}$ & $\begin{array}{c}\text { No-Surprise } \\
\mathrm{N}=39\end{array}$ & p-value \\
\hline BIG4 & 0.265 & 0.332 & 0.074 & 0.356 & 0.332 & 0.736 & 0.244 & 0.333 & 0.272 \\
\hline $\mathrm{GC}$ & 0.235 & 0.111 & 0.000 & 0.244 & 0.109 & 0.004 & 0.228 & 0.256 & 0.720 \\
\hline GROWTH & 0.275 & 0.118 & 0.251 & 0.342 & 0.114 & 0.547 & 0.331 & 0.090 & 0.022 \\
\hline LNTA & 17.662 & 17.878 & 0.493 & 17.327 & 17.886 & 0.027 & 17.665 & 17.650 & 0.630 \\
\hline LNTEN & 1.355 & 1.490 & 0.026 & 1.401 & 1.491 & 0.320 & 1.347 & 1.381 & 0.800 \\
\hline LOSS & 0.759 & 0.643 & 0.002 & 0.800 & 0.641 & 0.027 & 0.748 & 0.795 & 0.553 \\
\hline NASR & 0.248 & 0.177 & 0.142 & 0.125 & 0.178 & 0.058 & 0.230 & 0.304 & 0.886 \\
\hline REST & 0.253 & 0.164 & 0.003 & 0.556 & 0.158 & 0.000 & 0.205 & 0.410 & 0.010 \\
\hline ROA & -0.332 & -0.219 & 0.001 & -0.521 & -0.214 & 0.000 & -0.325 & -0.355 & 0.216 \\
\hline VOTE & 0.104 & -0.029 & 0.133 & -0.438 & -0.022 & 0.047 & -0.033 & 0.552 & 0.050 \\
\hline
\end{tabular}


Table 17

Surprise MW Disclosures and Shareholder Auditor Ratification Vote Non-Accelerated Filers

Panel A: Univariate Analysis of VOTE

\begin{tabular}{|l|c||c||c|}
\hline & Full Sample & Clean SOX 404 Sample & MW Sample \\
\hline & Section 404 MW Disclosure & Section 302 MW Disclosure & Surprise MW Disclosure \\
\hline Yes & 0.104 & -0.438 & -0.033 \\
\hline No & -0.029 & -0.022 & 0.552 \\
\hline & $\mathrm{T}=-1.08, \mathrm{p}=0.28$ & $\mathrm{~T}=1.81, \mathrm{p}=0.07$ & $\mathrm{~T}=-1.91, \mathrm{p}=0.06$ \\
\hline
\end{tabular}

Panel D: Regression Analysis

\begin{tabular}{|c|c|c|c|c|c|c|}
\hline \multirow{2}{*}{ VARIABLES } & \multicolumn{2}{|c|}{ Full Sample } & \multicolumn{2}{|c|}{ Clean SOX 404 Sample } & \multicolumn{2}{|c|}{ MW Sample } \\
\hline & Coefficient & p-value & Coefficient & & Coefficient & p-value \\
\hline CONSTANT & 0.787 & 0.110 & 0.696 & 0.164 & 2.520 & 0.373 \\
\hline MW & 0.046 & 0.704 & & & & \\
\hline PSURP & & & -0.552 & 0.016 & & \\
\hline SURP & & & & & -0.675 & 0.040 \\
\hline LNTA & -0.051 & 0.026 & -0.050 & 0.033 & -0.037 & 0.787 \\
\hline BIG4 & -0.323 & 0.000 & -0.349 & 0.000 & -0.188 & 0.627 \\
\hline NASR & 0.077 & 0.359 & 0.142 & 0.120 & -0.172 & 0.463 \\
\hline LNTEN & 0.170 & 0.000 & 0.187 & 0.000 & -0.110 & 0.546 \\
\hline GC & 0.280 & 0.004 & 0.281 & 0.005 & 0.650 & 0.119 \\
\hline REST & 0.124 & 0.089 & 0.146 & 0.055 & -0.151 & 0.633 \\
\hline LOSS & 0.083 & 0.222 & 0.100 & 0.149 & -0.557 & 0.122 \\
\hline GROWTH & -0.099 & 0.012 & -0.054 & 0.194 & -0.390 & 0.004 \\
\hline ROA & -0.195 & 0.045 & -0.265 & 0.008 & 0.683 & 0.111 \\
\hline $\begin{array}{l}\text { Industry } \\
\text { Dummies }\end{array}$ & \multicolumn{2}{|c|}{ Included } & \multicolumn{2}{|c|}{ Included } & \multicolumn{2}{|c|}{ Included } \\
\hline Year Dummies & \multicolumn{2}{|c|}{ Included } & \multicolumn{2}{|c|}{ Included } & \multicolumn{2}{|c|}{ Included } \\
\hline $\mathrm{N}$ & \multicolumn{2}{|c|}{3181} & \multicolumn{2}{|c|}{3015} & \multicolumn{2}{|c|}{166} \\
\hline $\mathrm{F}$ & \multicolumn{2}{|c|}{6.682} & \multicolumn{2}{|c|}{7.323} & \multicolumn{2}{|c|}{1.438} \\
\hline $\mathrm{p}$ & \multicolumn{2}{|c|}{0.000} & \multicolumn{2}{|c|}{0.000} & \multicolumn{2}{|c|}{0.103} \\
\hline Adjusted R2 & \multicolumn{2}{|c|}{0.039} & \multicolumn{2}{|c|}{0.046} & \multicolumn{2}{|c|}{0.058} \\
\hline
\end{tabular}


Table 18

Mean Values - Audit Fee Analysis Accelerated Filers

\begin{tabular}{|c|c|c|c|c|c|c|c|c|c|}
\hline \multicolumn{10}{|c|}{ Accelerated Filers } \\
\hline \multirow{2}{*}{ VARIABLES } & \multicolumn{3}{|c|}{ Full Sample } & \multicolumn{3}{|c|}{ Clean SOX 404 Sample } & \multicolumn{3}{|c|}{ MW Sample } \\
\hline & $\begin{array}{c}\text { SOX } 404 \mathrm{MW} \\
\mathrm{N}=1146\end{array}$ & $\begin{array}{c}\text { Clean SOX } 404 \\
\mathrm{~N}=27988\end{array}$ & $\mathrm{p}$-value & $\begin{array}{c}\text { SOX } 302 \mathrm{MW} \\
\mathrm{N}=325\end{array}$ & $\begin{array}{c}\text { Clean SOX } 302 \\
\mathrm{~N}=27663\end{array}$ & $\mathrm{p}$-value & $\begin{array}{c}\text { Negative Surprise } \\
\mathrm{N}=893\end{array}$ & $\begin{array}{c}\text { No-Surprise } \\
\mathrm{N}=253\end{array}$ & $\mathrm{p}$-value \\
\hline LAFEE & 14.077 & 14.066 & 0.214 & 14.075 & 14.065 & 0.727 & 14.007 & 14.324 & 0.000 \\
\hline LNTA & 19.942 & 20.671 & 0.000 & 20.081 & 20.678 & 0.000 & 19.912 & 20.052 & 0.141 \\
\hline ROA & -0.061 & -0.001 & 0.000 & -0.072 & 0.000 & 0.000 & -0.055 & -0.083 & 0.167 \\
\hline LEV & 0.520 & 0.511 & 0.734 & 0.515 & 0.511 & 0.669 & 0.510 & 0.556 & 0.023 \\
\hline SEGS & 2.353 & 2.531 & 0.002 & 2.249 & 2.534 & 0.003 & 2.355 & 2.344 & 0.970 \\
\hline $\mathrm{GC}$ & 0.041 & 0.011 & 0.000 & 0.022 & 0.011 & 0.077 & 0.034 & 0.067 & 0.017 \\
\hline INITIAL & 0.116 & 0.039 & 0.000 & 0.058 & 0.039 & 0.075 & 0.112 & 0.130 & 0.419 \\
\hline BIG4 & 0.763 & 0.844 & 0.000 & 0.852 & 0.844 & 0.673 & 0.758 & 0.779 & 0.498 \\
\hline XIDOP & 0.207 & 0.183 & 0.044 & 0.160 & 0.184 & 0.275 & 0.194 & 0.253 & 0.040 \\
\hline FOREIGN & 0.361 & 0.324 & 0.009 & 0.326 & 0.324 & 0.943 & 0.358 & 0.372 & 0.700 \\
\hline SPECIALIST & 0.231 & 0.262 & 0.019 & 0.249 & 0.262 & 0.593 & 0.223 & 0.261 & 0.206 \\
\hline INVREC & 0.234 & 0.226 & 0.135 & 0.206 & 0.226 & 0.009 & 0.238 & 0.219 & 0.142 \\
\hline CRATIO & 0.487 & 0.459 & 0.000 & 0.504 & 0.459 & 0.002 & 0.489 & 0.480 & 0.627 \\
\hline RESTATE & 0.223 & 0.070 & 0.000 & 0.640 & 0.063 & 0.000 & 0.111 & 0.617 & 0.000 \\
\hline
\end{tabular}


Table 19

Audit Fee Analysis - Accelerated Filers

\begin{tabular}{|c|c|c|c|c|c|c|}
\hline & \multicolumn{2}{|c|}{ Full Sample } & \multicolumn{2}{|c|}{ Clean SOX 404 Sample } & \multicolumn{2}{|c|}{ MW Sample } \\
\hline VARIABLES & Coefficient & p-value & Coefficient & $\mathrm{p}$-value & Coefficient & $\mathrm{p}$-value \\
\hline CONSTANT & 3.254 & 0.000 & 3.244 & 0.000 & 4.008 & 0.000 \\
\hline$M W$ & 0.348 & 0.000 & & & & \\
\hline PSURP & & & 0.198 & 0.000 & & \\
\hline$S U R P$ & & & & & -0.205 & 0.000 \\
\hline LNTA & 0.487 & 0.000 & 0.487 & 0.000 & 0.473 & 0.000 \\
\hline$R O A$ & -0.242 & 0.000 & -0.245 & 0.000 & -0.159 & 0.069 \\
\hline$L E V$ & 0.261 & 0.000 & 0.258 & 0.000 & 0.336 & 0.000 \\
\hline SEGS & 0.062 & 0.000 & 0.063 & 0.000 & 0.028 & 0.028 \\
\hline$G C$ & 0.012 & 0.682 & 0.012 & 0.683 & 0.008 & 0.933 \\
\hline INITIAL & -0.051 & 0.001 & -0.047 & 0.002 & -0.103 & 0.086 \\
\hline$B I G 4$ & 0.332 & 0.000 & 0.325 & 0.000 & 0.450 & 0.000 \\
\hline$X I D O P$ & 0.146 & 0.000 & 0.149 & 0.000 & 0.098 & 0.038 \\
\hline FOREIGN & 0.211 & 0.000 & 0.211 & 0.000 & 0.187 & 0.000 \\
\hline SPECIALIST & 0.037 & 0.000 & 0.036 & 0.000 & 0.063 & 0.163 \\
\hline INVREC & 0.236 & 0.000 & 0.236 & 0.000 & 0.330 & 0.009 \\
\hline CRATIO & 0.549 & 0.000 & 0.55 & 0.000 & 0.462 & 0.000 \\
\hline RESTATE & 0.099 & 0.000 & 0.077 & 0.000 & 0.010 & 0.847 \\
\hline Industry Dummies & \multicolumn{2}{|c|}{ Included } & \multicolumn{2}{|c|}{ Included } & \multicolumn{2}{|c|}{ Included } \\
\hline Year Dummies & \multicolumn{2}{|c|}{ Included } & \multicolumn{2}{|c|}{ Included } & \multicolumn{2}{|c|}{ Included } \\
\hline $\mathrm{N}$ & \multicolumn{2}{|c|}{29134} & \multicolumn{2}{|c|}{27988} & \multicolumn{2}{|c|}{1146} \\
\hline $\mathrm{F}$ & \multicolumn{2}{|c|}{3603} & \multicolumn{2}{|c|}{3561} & \multicolumn{2}{|c|}{86.82} \\
\hline $\mathrm{p}$ & \multicolumn{2}{|c|}{0.000} & \multicolumn{2}{|c|}{0.000} & \multicolumn{2}{|c|}{0.000} \\
\hline Adjusted R-square & \multicolumn{2}{|c|}{0.788} & \multicolumn{2}{|c|}{0.792} & \multicolumn{2}{|c|}{0.692} \\
\hline
\end{tabular}


Table 20

Mean Values - Audit Fee Analysis Non-Accelerated Filers

\begin{tabular}{|c|c|c|c|c|c|c|c|c|c|}
\hline \multirow{2}{*}{ VARIABLES } & \multicolumn{3}{|c|}{ Full Sample } & \multicolumn{3}{|c|}{ Clean SOX 404 Sample } & \multicolumn{3}{|c|}{ MW Sample } \\
\hline & $\begin{array}{c}\text { SOX } 404 \mathrm{MW} \\
\mathrm{N}=744\end{array}$ & $\begin{array}{c}\text { Clean SOX } 404 \\
\mathrm{~N}=6749\end{array}$ & $\mathrm{p}$-value & $\begin{array}{c}\text { SOX } 302 \mathrm{MW} \\
\mathrm{N}=139 \\
\end{array}$ & $\begin{array}{c}\text { Clean SOX 302 } \\
\mathrm{N}=6610\end{array}$ & $\mathrm{p}$-value & $\begin{array}{c}\text { Negative Surprise } \\
\mathrm{N}=575\end{array}$ & $\begin{array}{c}\text { No-Surprise } \\
\mathrm{N}=169\end{array}$ & p-value \\
\hline LAFEE & 12.254 & 12.521 & 0.000 & 12.631 & 12.519 & 0.072 & 12.201 & 12.434 & 0.052 \\
\hline LNTA & 17.246 & 17.874 & 0.000 & 17.524 & 17.881 & 0.033 & 17.218 & 17.342 & 0.345 \\
\hline ROA & -0.414 & -0.213 & 0.000 & -0.375 & -0.209 & 0.000 & -0.408 & -0.434 & 0.276 \\
\hline LEV & 0.732 & 0.538 & 0.000 & 0.670 & 0.535 & 0.000 & 0.736 & 0.717 & 0.763 \\
\hline SEGS & 1.426 & 1.720 & 0.000 & 1.446 & 1.726 & 0.002 & 1.456 & 1.325 & 0.212 \\
\hline $\mathrm{GC}$ & 0.388 & 0.142 & 0.000 & 0.237 & 0.140 & 0.001 & 0.386 & 0.396 & 0.808 \\
\hline INITIAL & 0.250 & 0.107 & 0.000 & 0.187 & 0.105 & 0.002 & 0.242 & 0.278 & 0.338 \\
\hline BIG4 & 0.227 & 0.334 & 0.000 & 0.381 & 0.333 & 0.234 & 0.216 & 0.266 & 0.168 \\
\hline XIDOP & 0.132 & 0.131 & 0.937 & 0.165 & 0.130 & 0.219 & 0.125 & 0.154 & 0.334 \\
\hline FOREIGN & 0.172 & 0.194 & 0.158 & 0.209 & 0.193 & 0.648 & 0.176 & 0.160 & 0.631 \\
\hline SPECIALIST & 0.059 & 0.095 & 0.001 & 0.079 & 0.095 & 0.527 & 0.057 & 0.065 & 0.710 \\
\hline INVREC & 0.235 & 0.256 & 0.000 & 0.225 & 0.257 & 0.086 & 0.247 & 0.194 & 0.010 \\
\hline CRATIO & 0.497 & 0.562 & 0.000 & 0.542 & 0.562 & 0.594 & 0.502 & 0.480 & 0.424 \\
\hline RESTATE & 0.137 & 0.060 & 0.000 & 0.424 & 0.052 & 0.000 & 0.089 & 0.302 & 0.000 \\
\hline
\end{tabular}


Table 21

Audit Fee Analysis - Non-Accelerated Filers

\begin{tabular}{|c|c|c|c|c|c|c|}
\hline \multirow[b]{2}{*}{ VARIABLES } & \multicolumn{2}{|c|}{ Full Sample } & \multicolumn{2}{|c|}{ Clean SOX 404 Sample } & \multicolumn{2}{|c|}{ MW Sample } \\
\hline & Coef. & p-value & Coef. & p-value & Coef. & p-value \\
\hline CONSTANT & 4.251 & 0.000 & 4.277 & 0.000 & 4.471 & 0.000 \\
\hline$M W$ & 0.015 & 0.442 & & & & \\
\hline PSURP & & & 0.172 & 0.000 & & \\
\hline$S U R P$ & & & & & -0.129 & 0.013 \\
\hline LNTA & 0.437 & 0.000 & 0.434 & 0.000 & 0.442 & 0.000 \\
\hline$R O A$ & -0.252 & 0.000 & -0.249 & 0.000 & -0.273 & 0.000 \\
\hline$L E V$ & 0.214 & 0.000 & 0.239 & 0.000 & 0.097 & 0.043 \\
\hline$S E G S$ & 0.020 & 0.000 & 0.024 & 0.000 & -0.008 & 0.637 \\
\hline$G C$ & 0.022 & 0.246 & 0.053 & 0.009 & -0.101 & 0.077 \\
\hline INITIAL & -0.041 & 0.020 & -0.026 & 0.177 & -0.096 & 0.058 \\
\hline$B I G 4$ & 0.557 & 0.000 & 0.540 & 0.000 & 0.737 & 0.000 \\
\hline$X I D O P$ & 0.190 & 0.000 & 0.192 & 0.000 & 0.143 & 0.023 \\
\hline FOREIGN & 0.193 & 0.000 & 0.191 & 0.000 & 0.190 & 0.001 \\
\hline SPECIALIST & 0.011 & 0.629 & 0.014 & 0.526 & 0.014 & 0.894 \\
\hline INVREC & 0.062 & 0.050 & 0.044 & 0.179 & 0.193 & 0.087 \\
\hline CRATIO & 0.307 & 0.000 & 0.307 & 0.000 & 0.287 & 0.001 \\
\hline RESTATE & 0.067 & 0.003 & 0.021 & 0.407 & 0.108 & 0.096 \\
\hline Industry Dummies & \multicolumn{2}{|c|}{ Included } & \multicolumn{2}{|c|}{ Included } & \multicolumn{2}{|c|}{ Included } \\
\hline Year Dummies & \multicolumn{2}{|c|}{ Included } & \multicolumn{2}{|c|}{ Included } & \multicolumn{2}{|c|}{ Included } \\
\hline $\mathrm{N}$ & \multicolumn{2}{|c|}{7493} & \multicolumn{2}{|c|}{6749} & \multicolumn{2}{|c|}{744} \\
\hline $\mathrm{F}$ & \multicolumn{2}{|c|}{1119} & \multicolumn{2}{|c|}{1026} & \multicolumn{2}{|c|}{107.1} \\
\hline $\mathrm{p}$ & \multicolumn{2}{|c|}{0.000} & \multicolumn{2}{|c|}{0.000} & \multicolumn{2}{|c|}{0.000} \\
\hline Adjusted R-square & \multicolumn{2}{|c|}{0.801} & \multicolumn{2}{|c|}{0.804} & \multicolumn{2}{|c|}{0.794} \\
\hline
\end{tabular}


Table 22

Mean Values - Audit Report Lag

Accelerated Filers

\begin{tabular}{|c|c|c|c|c|c|c|c|c|c|}
\hline \multicolumn{10}{|c|}{ Accelerated Filers } \\
\hline \multirow[b]{2}{*}{ VARIABLES } & \multicolumn{3}{|c|}{ Full Sample } & \multicolumn{3}{|c|}{ Clean SOX 404 Sample } & \multicolumn{3}{|c|}{ MW Sample } \\
\hline & $\begin{array}{c}\text { SOX } 404 \mathrm{MW} \\
\mathrm{N}=1146\end{array}$ & $\begin{array}{c}\text { Clean SOX } 404 \\
\mathrm{~N}=27988\end{array}$ & p-value & $\begin{array}{c}\text { SOX } 302 \mathrm{MW} \\
\mathrm{N}=325 \\
\end{array}$ & $\begin{array}{c}\text { Clean SOX } 302 \\
\mathrm{~N}=27663\end{array}$ & p-value & $\begin{array}{c}\text { Negative Surprise } \\
\mathrm{N}=893\end{array}$ & $\begin{array}{c}\text { No-Surprise } \\
\mathrm{N}=253\end{array}$ & p-value \\
\hline LNARL & 4.431 & 4.091 & 0.000 & 4.195 & 4.090 & 0.000 & 4.414 & 4.490 & 0.158 \\
\hline AUCHG & 0.163 & 0.038 & 0.000 & 0.080 & 0.038 & 0.000 & 0.161 & 0.170 & 0.741 \\
\hline AUFEE & 0.005 & 0.002 & 0.000 & 0.004 & 0.002 & 0.000 & 0.004 & 0.006 & 0.034 \\
\hline $\mathrm{GC}$ & 0.041 & 0.011 & 0.000 & 0.022 & 0.011 & 0.077 & 0.034 & 0.067 & 0.017 \\
\hline HITECH & 0.397 & 0.330 & 0.000 & 0.388 & 0.329 & 0.026 & 0.395 & 0.403 & 0.822 \\
\hline INITIAL & 0.116 & 0.039 & 0.000 & 0.058 & 0.039 & 0.075 & 0.112 & 0.130 & 0.419 \\
\hline LNTA & 19.942 & 20.671 & 0.000 & 20.081 & 20.678 & 0.000 & 19.912 & 20.052 & 0.141 \\
\hline LEV & 0.520 & 0.511 & 0.734 & 0.515 & 0.511 & 0.669 & 0.510 & 0.556 & 0.023 \\
\hline LOSS & 0.451 & 0.262 & 0.000 & 0.400 & 0.261 & 0.000 & 0.443 & 0.478 & 0.326 \\
\hline SEGS & 2.353 & 2.531 & 0.002 & 2.249 & 2.534 & 0.003 & 2.355 & 2.344 & 0.970 \\
\hline OPIN & 0.394 & 0.303 & 0.000 & 0.320 & 0.302 & 0.490 & 0.384 & 0.427 & 0.219 \\
\hline RESTATE & 0.223 & 0.070 & 0.000 & 0.640 & 0.063 & 0.000 & 0.111 & 0.617 & 0.000 \\
\hline ROA & -0.061 & -0.001 & 0.000 & -0.072 & 0.000 & 0.000 & -0.055 & -0.083 & 0.167 \\
\hline XIDOP & 0.207 & 0.183 & 0.044 & 0.160 & 0.184 & 0.275 & 0.194 & 0.253 & 0.040 \\
\hline SPECIALIST & 0.231 & 0.262 & 0.019 & 0.249 & 0.262 & 0.587 & 0.223 & 0.261 & 0.206 \\
\hline BIG4 & 0.763 & 0.844 & 0.000 & 0.852 & 0.844 & 0.673 & 0.758 & 0.779 & 0.498 \\
\hline
\end{tabular}


Table 23

Audit Report Lag

Accelerated Filers

\begin{tabular}{|c|c|c|c|c|c|c|}
\hline \multirow[b]{2}{*}{ VARIABLES } & \multicolumn{2}{|c|}{ Full Sample } & \multicolumn{2}{|c|}{ Clean SOX 404 Sample } & \multicolumn{2}{|c|}{ MW Sample } \\
\hline & Coefficient & p-value & Coefficient & p-value & Coefficient & $\mathrm{p}$-value \\
\hline CONSTANT & 4.911 & 0.000 & 4.984 & 0.000 & 3.560 & 0.000 \\
\hline MW & 0.272 & 0.000 & & & & \\
\hline PSURP & & & 0.041 & 0.000 & & \\
\hline SURP & & & & & 0.017 & 0.617 \\
\hline AUCHG & 0.031 & 0.000 & 0.030 & 0.000 & 0.057 & 0.083 \\
\hline AUFEE & 5.282 & 0.000 & 3.289 & 0.000 & 21.501 & 0.000 \\
\hline $\mathrm{GC}$ & 0.066 & 0.000 & 0.054 & 0.000 & 0.217 & 0.001 \\
\hline HITECH & -0.026 & 0.000 & -0.027 & 0.000 & 0.002 & 0.942 \\
\hline INITIAL & 0.028 & 0.000 & 0.024 & 0.000 & 0.086 & 0.030 \\
\hline LEV & 0.028 & 0.000 & 0.027 & 0.000 & 0.046 & 0.310 \\
\hline LNTA & -0.043 & 0.000 & -0.047 & 0.000 & 0.029 & 0.017 \\
\hline LOSS & 0.037 & 0.000 & 0.034 & 0.000 & 0.037 & 0.201 \\
\hline SEGS & 0.002 & 0.003 & 0.003 & 0.001 & 0.003 & 0.673 \\
\hline OPIN & 0.021 & 0.000 & 0.013 & 0.000 & 0.143 & 0.000 \\
\hline RESTATE & 0.045 & 0.000 & 0.032 & 0.000 & 0.124 & 0.000 \\
\hline ROA & 0.006 & 0.488 & -0.013 & 0.108 & 0.154 & 0.016 \\
\hline XIDOP & 0.011 & 0.000 & 0.012 & 0.000 & -0.022 & 0.477 \\
\hline SPECIALIST & 0.004 & 0.159 & 0.006 & 0.033 & -0.017 & 0.569 \\
\hline BIG4 & -0.017 & 0.000 & -0.017 & 0.000 & -0.053 & 0.123 \\
\hline Industry Dummies & \multicolumn{2}{|c|}{ Included } & \multicolumn{2}{|c|}{ Included } & \multicolumn{2}{|c|}{ Included } \\
\hline Year Dummies & \multicolumn{2}{|c|}{ Included } & \multicolumn{2}{|c|}{ Included } & \multicolumn{2}{|c|}{ Included } \\
\hline $\mathrm{N}$ & \multicolumn{2}{|c|}{29134} & \multicolumn{2}{|c|}{27988} & \multicolumn{2}{|c|}{1146} \\
\hline $\mathrm{F}$ & \multicolumn{2}{|c|}{323.3} & \multicolumn{2}{|c|}{252.8} & \multicolumn{2}{|c|}{6.775} \\
\hline $\mathrm{p}$ & \multicolumn{2}{|c|}{0.000} & \multicolumn{2}{|c|}{0.000} & \multicolumn{2}{|c|}{0.000} \\
\hline Adjusted R-square & \multicolumn{2}{|c|}{0.261} & \multicolumn{2}{|c|}{0.224} & \multicolumn{2}{|c|}{0.139} \\
\hline
\end{tabular}


Table 24

Mean Values - Audit Report Lag Non-Accelerated Filers

\begin{tabular}{|c|c|c|c|c|c|c|c|c|c|}
\hline \multirow{2}{*}{ VARIABLES } & \multicolumn{3}{|c|}{ Full Sample } & \multicolumn{3}{|c|}{ Clean SOX 404 Sample } & \multicolumn{3}{|c|}{ MW Sample } \\
\hline & \begin{tabular}{|c|} 
SOX $404 \mathrm{MW}$ \\
$\mathrm{N}=744$ \\
\end{tabular} & $\begin{array}{c}\text { Clean SOX } 404 \\
\mathrm{~N}=6749 \\
\end{array}$ & $\mathrm{p}$-value & \begin{tabular}{|c|} 
SOX $302 \mathrm{MW}$ \\
$\mathrm{N}=139$ \\
\end{tabular} & $\begin{array}{c}\text { Clean SOX } 302 \\
\mathrm{~N}=6610\end{array}$ & p-value & \begin{tabular}{|c|}
$\begin{array}{c}\text { Negative Surprise } \\
\mathrm{N}=575\end{array}$ \\
\end{tabular} & \begin{tabular}{|c|} 
No-Surprise \\
$\mathrm{N}=169$ \\
\end{tabular} & $\mathrm{p}$-value \\
\hline LNARL & 4.591 & 4.337 & 0.000 & 4.424 & 4.335 & 0.000 & 4.588 & 4.583 & 0.170 \\
\hline AUCHG & 0.203 & 0.080 & 0.000 & 0.201 & 0.078 & 0.000 & 0.200 & 0.207 & 0.840 \\
\hline AUFEE & 0.011 & 0.008 & 0.000 & 0.011 & 0.008 & 0.000 & 0.011 & 0.012 & 0.520 \\
\hline $\mathrm{GC}$ & 0.388 & 0.142 & 0.000 & 0.237 & 0.140 & 0.001 & 0.386 & 0.396 & 0.808 \\
\hline HITECH & 0.329 & 0.405 & 0.000 & 0.338 & 0.406 & 0.107 & 0.339 & 0.296 & 0.293 \\
\hline INITIAL & 0.250 & 0.107 & 0.000 & 0.187 & 0.105 & 0.002 & 0.242 & 0.278 & 0.338 \\
\hline LNTA & 17.246 & 17.873 & 0.000 & 17.524 & 17.881 & 0.033 & 17.218 & 17.342 & 0.345 \\
\hline LEV & 0.732 & 0.538 & 0.000 & 0.670 & 0.535 & 0.000 & 0.736 & 0.717 & 0.763 \\
\hline LOSS & 0.778 & 0.627 & 0.000 & 0.734 & 0.625 & 0.009 & 0.774 & 0.793 & 0.602 \\
\hline SEGS & 1.426 & 1.720 & 0.000 & 1.446 & 1.726 & 0.002 & 1.456 & 1.325 & 0.212 \\
\hline OPIN & 0.132 & 0.159 & 0.048 & 0.122 & 0.160 & 0.227 & 0.132 & 0.130 & 0.947 \\
\hline RESTATE & 0.137 & 0.060 & 0.000 & 0.424 & 0.052 & 0.000 & 0.089 & 0.302 & 0.000 \\
\hline ROA & -0.414 & -0.213 & 0.000 & -0.375 & -0.209 & 0.000 & -0.408 & -0.434 & 0.276 \\
\hline XIDOP & 0.132 & 0.131 & 0.937 & 0.165 & 0.130 & 0.219 & 0.125 & 0.154 & 0.334 \\
\hline SPECIALIST & 0.059 & 0.095 & 0.001 & 0.079 & 0.095 & 0.527 & 0.057 & 0.065 & 0.710 \\
\hline BIG4 & 0.227 & 0.334 & 0.000 & 0.381 & 0.333 & 0.234 & 0.216 & 0.266 & 0.168 \\
\hline
\end{tabular}


Table 25

Audit Report Lag Non-Accelerated Filers

\begin{tabular}{|c|c|c|c|c|c|c|}
\hline \multirow{2}{*}{ VARIABLES } & \multicolumn{2}{|c|}{ Full Sample } & \multicolumn{2}{|c|}{ Clean SOX 404 Sample } & \multicolumn{2}{|c|}{ MW Sample } \\
\hline & Coefficient & $\mathrm{p}$-value & Coefficient & p-value & Coefficient & p-value \\
\hline CONSTANT & 5.015 & 0.000 & 5.066 & 0.000 & 4.789 & 0.000 \\
\hline$M W$ & 0.185 & 0.000 & & & & \\
\hline PSURP & & & 0.057 & 0.001 & & \\
\hline$S U R P$ & & & & & 0.027 & 0.411 \\
\hline$A U C H G$ & 0.038 & 0.000 & 0.034 & 0.000 & 0.051 & 0.134 \\
\hline AUFEE & -1.462 & 0.002 & -1.547 & 0.001 & -1.337 & 0.495 \\
\hline$G C$ & 0.081 & 0.000 & 0.077 & 0.000 & 0.117 & 0.001 \\
\hline HITECH & -0.016 & 0.013 & -0.015 & 0.011 & -0.024 & 0.489 \\
\hline INITIAL & 0.023 & 0.003 & 0.024 & 0.002 & 0.026 & 0.426 \\
\hline$L E V$ & 0.055 & 0.000 & 0.052 & 0.000 & 0.078 & 0.010 \\
\hline$L N T A$ & -0.041 & 0.000 & -0.044 & 0.000 & -0.018 & 0.160 \\
\hline$L O S S$ & 0.052 & 0.000 & 0.041 & 0.000 & 0.133 & 0.000 \\
\hline$S E G S$ & 0.005 & 0.010 & 0.008 & 0.000 & -0.011 & 0.330 \\
\hline$O P I N$ & 0.009 & 0.226 & 0.003 & 0.695 & 0.091 & 0.040 \\
\hline RESTATE & 0.044 & 0.000 & 0.023 & 0.025 & 0.092 & 0.025 \\
\hline$R O A$ & 0.072 & 0.000 & 0.060 & 0.000 & 0.131 & 0.001 \\
\hline$X I D O P$ & 0.025 & 0.001 & 0.011 & 0.108 & 0.156 & 0.000 \\
\hline SPECIALIST & -0.006 & 0.534 & -0.010 & 0.277 & 0.033 & 0.606 \\
\hline BIG4 & -0.044 & 0.000 & -0.042 & 0.000 & -0.077 & 0.090 \\
\hline Industry Dummies & \multicolumn{2}{|c|}{ Included } & \multicolumn{2}{|c|}{ Included } & \multicolumn{2}{|c|}{ Included } \\
\hline Year Dummies & \multicolumn{2}{|c|}{ Included } & \multicolumn{2}{|c|}{ Included } & \multicolumn{2}{|c|}{ Included } \\
\hline $\mathrm{N}$ & \multicolumn{2}{|c|}{7493} & \multicolumn{2}{|c|}{6749} & \multicolumn{2}{|c|}{744} \\
\hline $\mathrm{F}$ & \multicolumn{2}{|c|}{83.29} & \multicolumn{2}{|c|}{60.27} & \multicolumn{2}{|c|}{3.866} \\
\hline $\mathrm{p}$ & \multicolumn{2}{|c|}{0.000} & \multicolumn{2}{|c|}{0.000} & \multicolumn{2}{|c|}{0.000} \\
\hline Adjusted R-square & \multicolumn{2}{|c|}{0.242} & \multicolumn{2}{|c|}{0.203} & \multicolumn{2}{|c|}{0.101} \\
\hline
\end{tabular}




\section{REFERENCES}

Agrawal, A., \& Cooper, T. (2017). Corporate Governance Consequences of Accounting Scandals: Evidence from Top Management, CFO and Auditor Turnover. Quarterly Journal of Finance, 07(01), 1650014. https://doi.org/10.1142/S2010139216500142

AICPA. (1978). The Commission on Auditors' Responsibilities: Reports, Conclusions, and Recommendations. An Independent Commission Stablished by the American Institute of Certified Public Accountants.

Ashbaugh-Skaife, H., Collins, D. W., \& Kinney, W. R. (2007). The discovery and reporting of internal control deficiencies prior to SOX-mandated audits. Journal of Accounting and Economics, 44(1-2), 166-192. https://doi.org/10.1016/j.jacceco.2006.10.001

Ashbaugh-Skaife, H., Collins, D. W., Kinney, W. R., \& Lafond, R. (2008). The effect of SOX internal control deficiencies and their remediation on accrual quality. Accounting Review, 83(1), 217-250. https://doi.org/10.2308/accr.2008.83.1.217

Ashton, R. H., Graul, P. R., \& Newton, J. D. (1989). Audit Delay and The Timeliness of Corporate Reporting : Malaysian Evidence. Contemporary Accounting Research, $5(2), 657-673$.

Ashton, R. H., Willingham, J. J., \& Elliott, R. K. (1987). An Empirical Analysis of Audit Delay. Journal of Accounting Research, 25(2), 275. https://doi.org/10.2307/2491018

Bamber, E. M., Bamber, L. S., \& Schoderbek, M. P. (1993). Audit Structure and Other Determinants of Audit Report Lag: An Empirical Analysis. Auditing, 12(1), 1-23. https://doi.org/10.1017/CBO9781107415324.004

Barua, A., Raghunandan, K., \& Rama, D. V. (2017). Shareholder votes on auditor ratification and subsequent auditor dismissals. Accounting Horizons, 31(1), 129139. https://doi.org/10.2308/acch-51512

Beattie, V., \& Fearnley, S. (1995). The Importance of Audit Firm Characteristics and the Drivers of Auditor Change in UK Listed Companies. Accounting and Business Research, 25(100), 227-239. https://doi.org/10.1080/00014788.1995.9729912

Beck, P. J., \& Wu, martin G. H. (2006). Learning by doing and audit quality. Contemporary Accounting Research, 23(1), 1-30.

Bedard, J. C., Hoitash, U., \& Hoitash, R. (2008). Audit pricing and internal control disclosures among non-accelerated filers. Research in Accounting Regulation (Vol. 20). Elsevier Masson SAS. https://doi.org/10.1016/S1052-0457(07)00206-8 
Beneish, M. D., Billings, M. B., Hodder, L. D., Brooke, M., Hodder, L. D., Billings, M. B., \& Hodder, L. D. (2008). Internal control weaknesses and information uncertainty. Accounting Review, 83(3), 665-703. https://doi.org/10.2308/accr.2008.83.3.665

Bonsón-Ponte, E., Escobar-Rodríguez, T., \& Borrero-Domínguez, C. (2008). Empirical Analysis of Delays in the Signing of Audit Reports in Spain. International Journal of Auditing, 12, 129-140. https://doi.org/10.1111/j.1099-1123.2008.00375.x

Brown, J. R. J. (2012). The Politicization of Corporate Governance: Bureaucratic Discretion, the SEC, and Shareholder Ratification of Auditors. Harvard Business Law Review, 61, 501-534. https://doi.org/10.3366/ajicl.2011.0005

Carcello, J. V., \& Neal, T. L. (2003). Audit committee characteristics and auditor dismissals following "new" going-concern reports. Accounting Review, 78(1), 95117. https://doi.org/10.2308/accr.2003.78.1.95

Chan, K. C., Farrell, B., \& Lee, P. (2008). Earnings management of firms reporting material internal control weaknesses under section 404 of the Sarbanes-Oxley Act. Auditing, 27(2), 161-179. https://doi.org/10.2308/aud.2008.27.2.161

Chen, Y., Smith, A. L., Cao, J., \& Xia, W. (2014). Information Technology Capability, Internal Control Effectiveness, and Audit Fees and Delays. Journal of Information Systems, 28(2), 149-180. https://doi.org/10.2308/isys-50778

Costello, A. M., \& Wittenberg-Moerman, R. (2011). The Impact of Financial Reporting Quality on Debt Contracting: Evidence from Internal Control Weakness Reports. Journal of Accounting Research, 49(1), 97-136. https://doi.org/10.1111/j.1475679X.2010.00388.x

Cunningham, L. M. (2017). Auditor Ratification: Can't Get No (Dis)Satisfaction. Accounting Horizons, 31(1), 159-175. https://doi.org/10.2308/acch-51652

Dao, M., Huang, H. W., Chen, K. Y., \& Huang, T. C. (2014). Can management turnover restore the financial statement credibility of restating firms? Further evidence.

Journal of Business Finance and Accounting, 41(7-8), 893-925. https://doi.org/10.1111/jbfa.12081

Dao, M., Mishra, S., \& Raghunandan, K. (2008). Auditor tenure and shareholder ratification of the auditor. Accounting Horizons, 22(3), 297-314. https://doi.org/10.2308/acch.2008.22.3.297

Dao, M., \& Pham, T. (2014). Audit tenure, auditor specialization and audit report lag. Managerial Auditing Journal, 29(6), 490-512. https://doi.org/10.1108/MAJ-072013-0906 
De Angelo, L. E. (1981). Auditor size and audit quality. Journal of Accounting and Economics, 3(May), 183-199. https://doi.org/10.1016/0165-4101(81)90002-1

Desai, H., Hogan, C. E., \& Wilkins, M. S. (2006). The reputational penalty for aggressive accounting: Earnings restatements and management turnover. The Accounting Review, 81(1), 83-112. https://doi.org/10.2308/accr.2006.81.1.83

DFA. Dodd-Frank Wall Street Reform and Consumer Protection Act, H.R. 4173 The Senate and House of Representatives of the United States of America in Congress $\S$ (2010). https://doi.org/10.1097/01.NMC.0000357923.48724.d5

Dhaliwal, D., Hogan, C., Trezevant, R., \& Wilkins, M. (2011). Internal control disclosures, monitoring, and the cost of debt. Accounting Review, 86(4), 1131-1156. https://doi.org/10.2308/accr-10043

Doyle, J., Ge, W., \& McVay, S. (2007). Determinants of weaknesses in internal control over financial reporting. Journal of Accounting and Economics, 44(1-2), 193-223. https://doi.org/10.1016/j.jacceco.2006.10.003

Ettredge, M., Emeigh, E., \& Li, C. (2014). Fee pressure and audit quality. Accounting, Organizations and Society, 39(4), 247-263. https://doi.org/10.1016/j.aos.2014.04.002

Ettredge, M., Heintz, J., Li, C., \& Scholz, S. (2011). Auditor realignments accompanying implementation of SOX 404 ICFR reporting requirements. Accounting Horizons, 25(1), 17-39. https://doi.org/10.2308/acch.2011.25.1.17

Ettredge, M. L., Li, C., \& Scholz, S. (2007). Audit fees and auditor dismissals in the sarbanes-oxley era. Accounting Horizons, 21(4), 371-386. https://doi.org/10.2308/acch.2007.21.4.371

Ettredge, M., Li, C., \& Sun, L. (2006). The Impact of SOX Section 404 Internal Control Quality Assessment on Audit Delay in the SOX Era. AUDITING: A Journal of Practice \& Theory, 25(2), 1-23. https://doi.org/10.2308/aud.2006.25.2.1

Feng, M., Li, C., \& McVay, S. (2009). Internal control and management guidance. Journal of Accounting and Economics, 48(2-3), 190-209. https://doi.org/10.1016/j.jacceco.2009.09.004

Feng, M., Li, C., McVay, S. E., \& Skaife, H. (2015). Does Ineffective Internal Control over Financial Reporting affect a Firm's Operations? Evidence from Firms' Inventory Management. Accounting Review, 90(2), 529-557. https://doi.org/10.2308/accr-50909

Francis, J. R., \& Simon, D. (1987). A Test of Auditing Pricing in the Small-Client Segment of the US Audit Market. The Accounting Review, 62(1), 145-157. https://doi.org/10.2307/248051 
Franzel, J. M. (2016). Update on Trends and Issues in Audits of Internal Control over Financial Reporting. Retrieved from https://pcaobus.org/News/Speech/Pages/Franzel-speech-internal-control-overfinancial-reporting-AAA-08-06-2016.aspx

GAO. (2003). PUBLIC ACCOUNTING FIRMS: Mandated study on Consolidation and Competition. United States General Accounting Office, (July).

Gietzmann, M., Marra, A., \& Pettinicchio, A. (2016). Comment letter frequency and CFO turnover: A dynamic survival analysis. Journal of Accounting, Auditing and Finance, 31(1), 79-99. https://doi.org/10.1177/0148558X15579493

Glass Lewis \& Co. (2005). Control Deficiencies Trend Alert. Glass Lewis \& Co.

Gupta, P. P., \& Nayar, N. (2007). Information content of control deficiency disclosures under the Sarbanes-Oxley Act: An empirical investigation. International Journal of Disclosure and Governance, 4(1), 3-23. https://doi.org/10.1057/palgrave.jdg.2050047

Habib, A., \& Bhuiyan, M. B. U. (2011). Audit firm industry specialization and the audit report lag. Journal of International Accounting, Auditing and Taxation, 20(1), 3244. https://doi.org/10.1016/j.intaccaudtax.2010.12.004

Hammersley, J. S., Myers, L. A., \& Shakespeare, C. (2008). Market reactions to the disclosure of internal control weaknesses and to the characteristics of those weaknesses under section 302 of the Sarbanes Oxley Act of 2002. Review of Accounting Studies, 13(1), 141-165. https://doi.org/10.1007/s11142-007-9046-z

Hennes, K. M., Leone, A. J., \& Miller, B. P. (2014). Determinants and market consequences of auditor dismissals after accounting restatements. Accounting Review, 89(3), 1051-1082. https://doi.org/10.2308/accr-50680

Hermanson, D. R., Krishnan, J., \& Ye, Z. (2009). Adverse section 404 opinions and shareholder dissatisfaction toward auditors. Accounting Horizons, 23(4), 391-409. https://doi.org/10.2308/acch.2009.23.4.391

Hermanson, D. R., Rama, D. V., \& Ye, Z. (Shelly). (2017). Shareholder Proposals on the Auditor-Client Relationship: The Case of Nonaudit Service Purchases. Journal of Accounting, Auditing \& Finance, 0148558X1770408. https://doi.org/10.1177/0148558X17704085

Hermanson, D. R., \& Ye, Z. (2009). Why do some accelerated filers with SOX Section 404 material weaknesses provide early warning under section 302? Auditing, 28(2), 247-271. https://doi.org/10.2308/aud.2009.28.2.247 
Hoag, M. L., \& Hollingsworth, C. W. (2011). An intertemporal analysis of audit fees and section 404 material weaknesses. Auditing, 30(2), 173-200.

https://doi.org/10.2308/ajpt-50005

Hogan, C. E., \& Wilkins, M. S. (2008). Evidence on the audit risk model: Do auditors increase audit fees in the presence of internal control deficiencies? Contemporary Accounting Research, 25(1), 219-+. https://doi.org/10.1506/car.25.1.9

Hoitash, R., Hoitash, U., \& Bedard, J. C. (2008). Internal control quality and audit pricing under the Sarbanes-Oxley Act. Auditing: A Journal of Practice \& Theory, 27(1), 105-126. https://doi.org/10.2308/aud.2008.27.1.105

Hoitash, U., Hoitash, R., \& Bedard, J. C. (2009). Corporate governance and internal control over financial reporting: A comparison of regulatory regimes. The Accounting Review, 84(3), 839-867. https://doi.org/10.2308/accr.2009.84.3.839

Impink, J., Lubberink, M., van Praag, B., \& Veenman, D. (2012). Did accelerated filing requirements and SOX Section 404 affect the timeliness of 10-K filings? Review of Accounting Studies, 17(2), 227-253. https://doi.org/10.1007/s11142-011-9172-5

JOBS. (2012). Jumpstart Our Business Startups Act. The Senate and House of Representatives of the United States of America, (200), 1-23.

Johnstone, K., Li, C., \& Rupley, K. H. (2011). Changes in Corporate Governance Associated with the Revelation of Internal Control Material Weaknesses and Their Subsequent Remediation. Contemporary Accounting Research, 28(1), 331-383. https://doi.org/10.1111/j.1911-3846.2010.01037.x

Johnstone, K. M., \& Bedard, J. C. (2003). Risk Management in Client Acceptance Decisions. Accounting Review, 78(4), 1003-1025. https://doi.org/10.2308/accr.2003.78.4.1003

Kim, J. B., Song, B. Y., \& Zhang, L. (2011). Internal control weakness and bank loan contracting: Evidence from SOX section 404 disclosures. Accounting Review, 86(4), 1157-1188. https://doi.org/10.2308/accr-10036

Knechel, W. R., \& Payne, J. L. (2001). Additional evidence on audit report lag. Auditing, 20(1), 137-146. https://doi.org/10.2308/aud.2001.20.1.137

Kohlbeck, M., Mayhew, B. W., Murphy, P., \& Wilkins, M. S. (2008). Competition for Andersen's clients. Contemporary Accounting Research, 25(4), 1099-1136. https://doi.org/10.1506/car.25.4.6

Krishnan, J., Rama, D., \& Zhang, Y. (2008). Costs to comply with SOX section 404. Auditing, 27(1), 169-186. https://doi.org/10.2308/aud.2008.27.1.169 
Krishnan, J., \& Yang, J. S. (2009). Recent trends inaudit report and earnings announcement lags. Accounting Horizons, 23(3), 265-288.

https://doi.org/10.2308/acch.2009.23.3.265

Krishnan, G. V, \& Visvanathan, G. (2007). Reporting Internal Control Deficiencies in the Post-Sarbanes-Oxley Era: The Role of Auditors and Corporate Governance. International Journal of Auditing, 11(2), 73-90. https://doi.org/10.1111/j.10991123.2007.00358.x

Lee, H.-Y., Mande, V., \& Son, M. (2009). Do Lengthy Auditor Tenure and the Provision of Non-Audit Services by the External Auditor Reduce Audit Report Lags? International Journal of Auditing, 13(2), 87-104. https://doi.org/10.1111/j.10991123.2008.00406.x

Leone, A. J., \& Liu, M. (2010). Accounting irregularities and executive turnover in founder-managed firms. Accounting Review, 85(1), 287-314. https://doi.org/10.2308/accr.2010.85.1.287

Leventis, S., Weetman, P., \& Caramanis, C. (2005). Determinants of Audit Report Lag: Some Evidence From the Athens Stock Exchange. International Journal of Auditing, 9(1), 45-58. https://doi.org/10.1111/j.1099-1123.2005.00101.x

Li, C., Sun, L., \& Ettredge, M. (2010). Financial executive qualifications, financial executive turnover, and adverse SOX 404 opinions. Journal of Accounting and Economics, 50(1), 93-110. https://doi.org/10.1016/j.jacceco.2010.01.003

Mayhew, B. W. (2017). Introduction and Commentary on Ratification Research Forum. Accounting Horizons, 31(1), 125-128. https://doi.org/10.2308/acch-10519

McKenna, B. F. (2017). Latest version of Dodd-Frank reversal bill would exempt a third of public companies from giving auditor warning. MarketWatch, (Feb 16, 2017). Retrieved from https://www.marketwatch.com/story/latest-dodd-frank-reversal-billwould-exempt-a-third-of-public-companies-from-giving-auditor-warning-2017-0216

Mishra, S., Raghunandan, K., \& Rama, D. V. (2005). Do investors' perceptions vary with types of nonaudit fees? Evidence from auditor ratification voting. Auditing, 24(2), 9-25. https://doi.org/10.2308/aud.2005.24.2.9

Munsif, V., Raghunandan, K., \& Rama, D. V. (2012). Internal control reporting and audit report lags: Further evidence. Auditing, 31(3), 203-218. https://doi.org/10.2308/ajpt50190

Munsif, V., Raghunandan, K., \& Rama, D. V. (2013). Early warnings of internal control problems: Additional evidence. AUDITING: A Journal of Practice \& Theory, 32(2), 171-188. https://doi.org/10.2308/ajpt-50380 
Munsif, V., Raghunandan, K., Rama, D. V., \& Singhvi, M. (2011). Audit fees after remediation of internal control weaknesses. Accounting Horizons, 25(1), 87-105. https://doi.org/10.2308/acch.2011.25.1.87

Myers, J. N., Myers, L. A., \& Omer, T. C. (2003). Exploring the Term of the AuditorClient Relationship and the Quality of Earnings: A Case for Mandatory Auditor Rotation? The Accounting Review, 78(3), 779-799. https://doi.org/10.2308/accr.2003.78.3.779

Nicolaisen, D. T. (2004). Speech by SEC Staff : Keynote Speech at 11th Annual Midwestern Financial Reporting Symposium. SEC. Retrieved from https://www.sec.gov/news/speech/spch100704dtn.htm

PCAOB. (2007). Auditing Standard No. 5. An audit of internal control over financial reporting performed in conjunction with an audit of financial statements. Public Company Accounting Oversight Board. Retrieved from http://pcaobus.org/Standards/Auditing/Pages/Auditing_Standard_5.aspx

PCAOB. (2010a). AU Section 550 Other Information in Documents Containing Audited Financial Statements. Public Company Accounting Oversight Board.

PCAOB. (2010b). Auditing Standards Related to the Auditor's Assessment of and response to risk. Public Company Accounting Oversight Board. https://doi.org/10.1017/CBO9781107415324.004

Petrovits, C., Shakespeare, C., \& Shih, A. (2011). The causes and consequences of internal control problems in nonprofit organizations. Accounting Review, 86(1), 325-357. https://doi.org/10.2308/accr.00000012

Pham, T., Dao, M., \& Brown, V. L. (2014). Investment Opportunities and Audit Report Lags: Initial Evidence. Accounting and Finance Research, 3(4), 45-57. https://doi.org/10.5430/afr.v3n4p45

Raghunandan, K. (2003). Nonaudit services and shareholder ratification of auditors. Auditing: A Journal of Practice \& Theory.

Raghunandan, K., \& Rama, D. V. (2006). SOX section 404 material weakness disclosures and audit fees. AUDITING: A Journal of Practice \& Theory, 25(1), 99114. https://doi.org/10.2308/aud.2006.25.1.99

Rice, S. C., \& Weber, D. P. (2012). How Effective Is Internal Control Reporting under SOX 404? Determinants of the (Non-)Disclosure of Existing Material Weaknesses. Journal of Accounting Research, 50(3), 811-843. https://doi.org/10.1111/j.1475679X.2011.00434.x 
Rice, S. C., Weber, D. P., \& Wu, B. (2015). Does SOX 404 Have Teeth? Consequences of the Failure to Report Existing Internal Control Weaknesses. The Accounting Review, 90(3), 1169-1200. https://doi.org/10.2308/accr-50974

Richardson, S. a., Tuna, a. I., \& Wu, M. (2002). Predicting Earnings Management: The Case of Earnings Restatements. SSRN Electronic Journal, (October 2002). https://doi.org/10.2139/ssrn.338681

Sainty, B. J., Taylor, G. K., \& Williams, D. D. (2002). Investor Dissatisfaction toward Auditors. Journal of Accounting, Auditing \& Finance, 17(2), 111-136. https://doi.org/10.1177/0148558X0201700202

Schwartz, K. B., \& Soo, B. S. (1996). The Association Between Auditor Changes and Reporting Lags. Contemporary Accounting Research, 13(1), 353-370.

SEC. (2003). Management's Report on Internal Control Over Financial Reporting and Certification of Disclosure in Exchange Act Periodic Reports. Securities and Exchange Commission.

SEC. (2004). Management's Report on Internal Control Over Financial Reporting and Certification of Disclosure in Exchange Act Periodic Reports - Frequently Asked Questions. Securities and Exchange Commission.

SEC. (2005). Revisions to accelerated filer definition and accelerated deadlines for filing periodic reports. Washington DC: Securities and Exchange Commission. Retrieved from https://www.sec.gov/rules/final/33-8644.pdf

Steinberg, R. M. (2005). Directional Shifts : 404 Moves From Project To Process. Compliance Week, (November 22, 2005).

Sun, Y. (2016). Internal Control Weakness Disclosure and Firm Investment. Journal of Accounting, Auditing \& Finance, 31(2), 277-307. https://doi.org/10.1177/0148558X15598027

Tanyi, P. N., \& Roland, K. C. (2017). Market Reaction to Auditor Ratification Vote Tally. Accounting Horizons, 31(1), 141-157. https://doi.org/10.2308/acch-51656

Tanyi, P., Raghunandan, K., \& Barua, A. (2010). Audit report lags after voluntary and involuntary auditor changes. Accounting Horizons, 24(4), 671-688. https://doi.org/10.2308/acch.2010.24.4.671

U.S. House of Representatives. Financial CHOICE Act of 2017 (2017).

United States Congress. The Sarbanes-Oxley Act of 2002, Pub. L. No. 107-204 H.R. 3763 (2002). Washington, DC. 
United States Treasury. (2008). Final Report of the Advisory Committee on the Auditing Profession to the U.S. Department of the Treasury. Advisory Committe on the Audit Profession.

Villalonga, B., \& Amit, R. (2006). How do family ownership, control and management affect firm value? Journal of Financial Economics, 80(2), 385-417. https://doi.org/10.1016/j.jfineco.2004.12.005

Wang, Y.-F., \& Huang, Y.-T. (2013). The Impact of Internal Control Quality on CFO Turnover. Asian Journal of Finance \& Accounting, 5(1), 334-343. https://doi.org/10.5296/ajfa.v5i1.3641 
VITA

\section{HAMBISA BELINA}

Born, Nedjo, Oromia

1981-1985

1985-1987

1987-1998

1994-1997

$1998-2000$

2000-2008

2008-2014

2011-2013

2013-Present

2014-2018

2014-2018

2014-Present

2016
BA Accounting

University of Asmara,

Asmara, Eritrea

Staff Accountant

Ethiopian Evangelical Church Mekane Yesus

Addis Ababa, Ethiopia

Sr. Systems Specialist / Network Administrator

International Livestock Research Institute (ILRI)

Addis Ababa, Ethiopia

MSc. Information Science

Addis Ababa University,

Addis Ababa, Ethiopia

Network Admin./ Data Management Specialist

Tetra Tech ARD

Arlington, Virginia

Sr. Systems/Financial Specialist

BISYS /Potomac Partners

Bethesda, Maryland

Finance Manager

Morgan State University

Baltimore, Maryland

MBA Accounting

Morgan State University

Baltimore, Maryland

Beta Gamma Sigma Honor Society

Doctoral Candidate

Florida International University

Miami, Florida

Teaching Assistant

Florida International University

Miami, Florida

KPMG Doctoral Scholar

Doctoral Consortium Fellow

AAA/Deloitte Foundation/J. Michael Cook Doctoral Consortium

\section{RESEARCH PRESENTATIONS}

April 2017: 'Surprise' Internal Control Weakness Disclosures: Frequencies, Factors, and Shareholder Voting Reactions, Florida International University, Miami, FL. 